\title{
Avaliação de Aspectos de Segurança em Comunicações no Âmbito de Empresas Virtuais
}

\author{
Alessandro de Castro Borges
}

Orientador: Prof. Dr. Edson dos Santos Moreira

Dissertação apresentada ao Instituto de Ciências Matemáticas e de Computação - ICMC-USP, como parte dos requisitos para obtenção do título de Mestre em Ciências - Área: Ciências de Computação e Matemática Computacional. 
Aos meus pais,

Ignêz e Joaquim.

À minha irmã, minha noiva $e$ meus amigos. 


\section{Agradecimentos}

Primeiramente a Deus e Nossa Senhora, pela ajuda e força que sempre recebi em diferentes ocasiões, e com Quem continuarei contando em todas as situações da minha vida.

Meus pais, que estiveram sempre ao meu lado. Por eles, e por seus esforços, me foi possivel encarar a caminhada e dar mais esse passo.

Prof. Dr. Edson dos Santos Moreira, pela acolhida, orientação e amizade, desenvolvidas ao longo dos anos de convivência que vêem desde a graduação no ICMC.

CAPES e FAPESP pelo apoio e patrocínio parcial do projeto.

Matite, companheiro de república por bons 6 anos, muitas vezes ouvindo lamentos e reclamações, e tantas outras partilhando alegrias e conquistas.

Júlio, Mirla, Taboca, Roberto, Zé Mauricio, os membros da Jbe Computing Society, e tantos outros que não citarei explicitamente para evitar injustiças que sempre acontecem quando queremos lembrar de todos, mas que dividiram muitos momentos, de trabalho e lazer.

Chico Milagres e Ton Brandão, pela disposição e ajuda no projeto.

Rudinei Goulart, grande amigo, que deu uma ajuda importantíssima na hora do sufoco final.

Beth, Marilia, Laura, Paulinho, Sandra e Adriana, pelo tempo de convivência, amizade e auxilio.

Colegas do ICMC, pelo ambiente agradável de convivência.

Eu não poderia deixar de fazer um agradecimento especial a uma pessoa que me ajudou muito em um tempo muito dificil. Essa pessoa ajudou a clarear um céu que estava carregado de nuvens pesadas e pretas, abrindo um novo horizonte. Tenho uma admiração e um carinho muito grande por ela, e espero não perder sua amizade pelo resto de minha vida. Um grande agradecimento, e um forte abraço, sinceros, a Thelma, uma amiga muito especial que tive o privilégio e prazer de conquistar durante o mestrado.

Ao pessoal do Trem Bão pelas horas de lazer, animação e alimentação proporcionadas em diferentes situações (desde festas a intervalos entre períodos de estudo e trabalho), e a todos aqueles que, de uma forma ou de outra, ajudaram ou torceram por mim. 


\section{ÍNDICE}

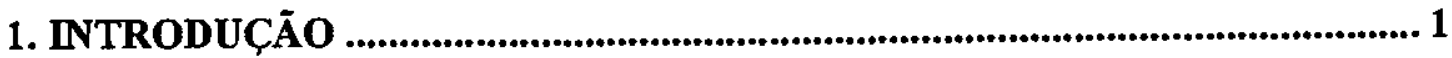

2. EMPRESAS VIRTUAIS E SISTEMAS DE INFORMAÇÃO .........................5

2.1. Empresas Virtuais ............................................................................................5

2.2. Demanda por Sistemas de Informação no Processo de uma Empresa Virtual.....10

2.2.1. Identificação de Oportunidades...........................................................10

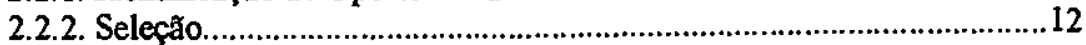

2.2.3. Formação....................................................................................... 14

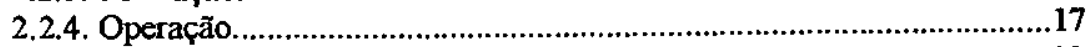

Sumário

5
10
7
7
9

3. INFRA-ESTRUTURA DE INFORMAÇÃO PARA

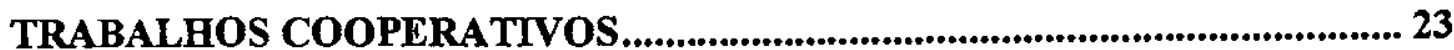

3.1. Gerenciamento de Sistemas de Arquivos e Diretórios..............................23

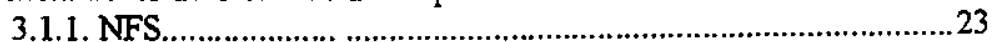

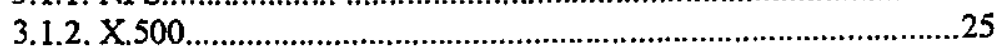

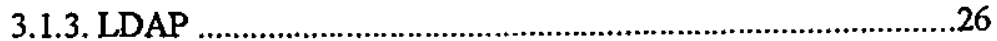

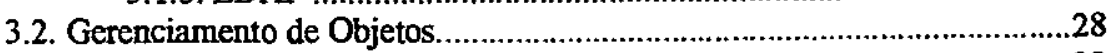

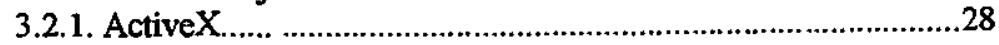

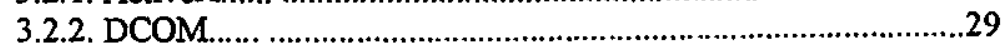

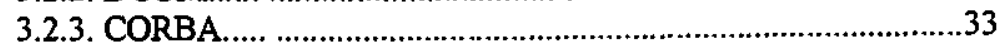

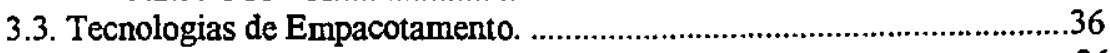

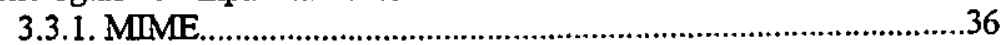

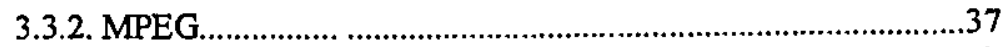

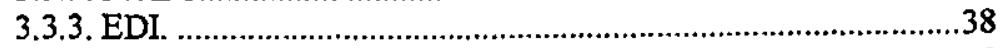

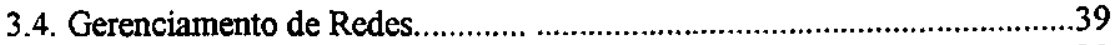

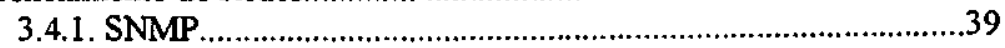

3.5. Tecnologia de Agentes Móveis......................................................40

3.5.1. Agentes.....................................................................40

3.5.2. Agentes Móveis..............................................................43

3.5.3. Segurança de Agentes....................................................45

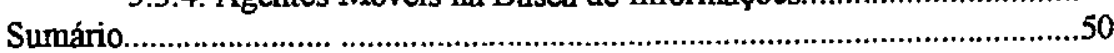

4. PROTEÇÃO DA INFORMAÇÃO ................................................................ 51

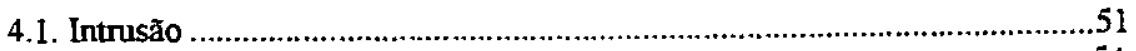

4.2. Avaliação de Vulnerabilidades em Sistemas de Informação..........................54

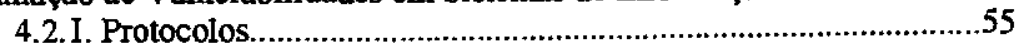

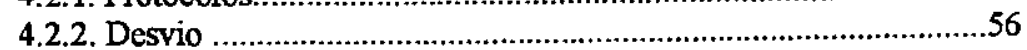

4.2.3.Perda de propriedade intelectual ............................................5 
4.2.4. Cópia ilegal .........................................................................57

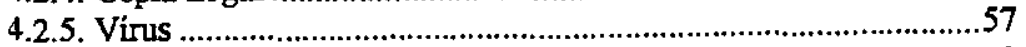

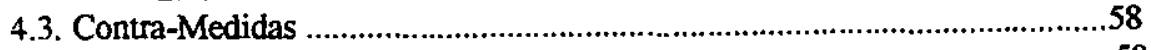

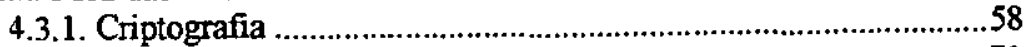

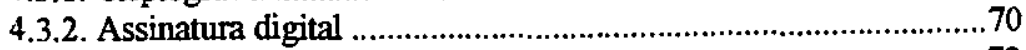

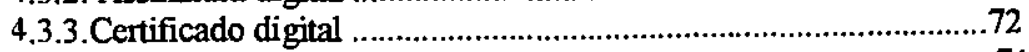

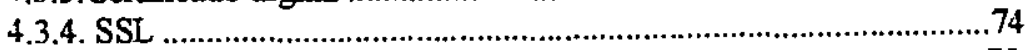

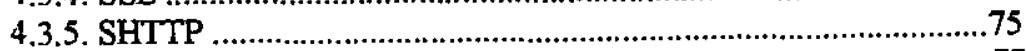

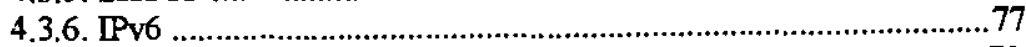

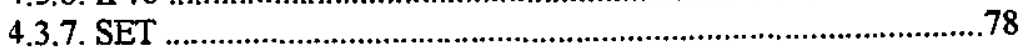

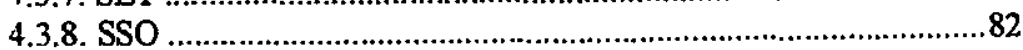

4.3.9. Firewalls .............................................................................. 86

4.3.10. Sistema de detecção de intrusão............................................... 87

4.3.11. Proteção de arquivos (criptografia)...........................................88

4.3.12. Proteção contra applets Java e ActiveX ……….........................88

4.3.13. Proteção contra vírus ...............................................................88

4.3.14. Monitoramento

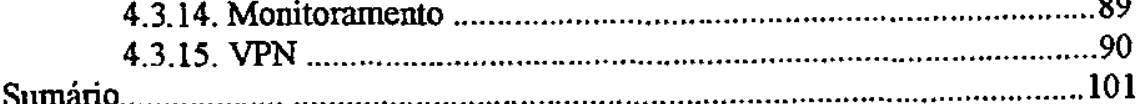

5. PROPOSTA DE UM AMBIENTE SEGURO PARA EV'S ........................ 103

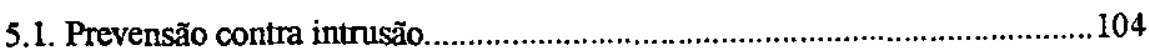

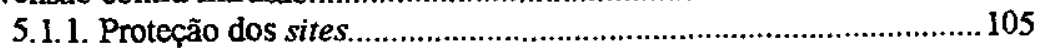

5.1.2. Proteção das comunicações.........................................................110

5.1.3. Proteção para ambas as partes (sites e comunicações)..................111

5.2. Possiveis pontos de quebra de segurança....................................................112

5.3. Politicas de segurança..............................................................................113

5.3.1. Deixar claro o que está sendo protegido e especificar a responsbilidade pela proteção.........................................................................................114

5.3.2. Segurança fisica dos equipamentos pertencentes à rede...............114

5.3.3. Serviços oferecidos e permitidos aos usuários da rede...................116

5.3.4. Açōes sobre os equipamentos da rede..........................................117

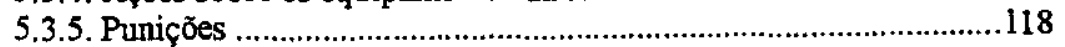

Sumário

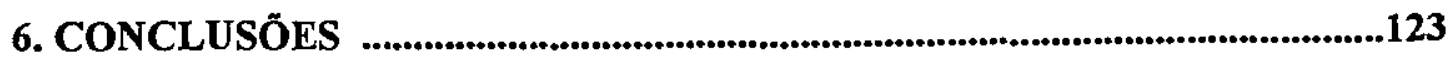

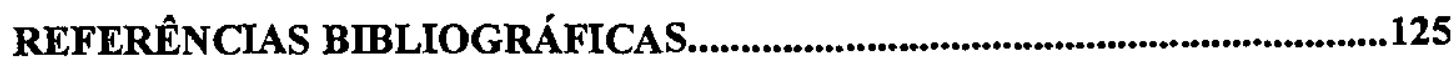

APÊNDICES: 


\section{LISTA DE FIGURAS}

2.1 .

2.2 .

3.1 .

3.2 .

3.3.

3.4 .

3.5 .

3.6 .

3.7

3.8 .

3.9 .

4.1.

4.2 .

4.3 .

4.4 .

4.5 .

4.6.

4.7.

4.8 .

4.9 .

4.10 .

4.11 .

4.12.

4.13.

4.14 .

4. 15 .

4.16.

4.17.

4.18 .

4.19 .

4.20 .

4.21 .

5.1 .

Intercomunicação para troca de mensagens via RC $\quad 007$

Estrutura de uma Empresa Virtual Dinâmica $\quad 009$

Como um sistema remoto é incorporado à árvore do $\quad 024$

sistema de arquivos do cliente

Componentes COM em processos diferentes $\quad 030$

Componentes COM em máquinas diferentes 031

DCOM no centro dos componentes da aplicação 032

Interligação usando CORBA 033

Integração através da IDL $\quad 034$

Arquitetura ORB do CORBA 035

Cenário da busca por oportunidade de negócio 048

Cenário da busca por competências relevantes à 050

exploração da oportunidade na intenção de encontrar parceiros em potencial para formar uma $\mathrm{EV}$

Intrusão em transferência de dados 053

O modelo do processo de Criptografia $\quad 060$

Exemplo de Transposição de Cifras 062

Elementos básicos de "product ciphers" 064

O padrão de criptografia de dados 066

Modelo de criptografia com chave pública 068

Criptografia usando RSA 069

Assinatura digital com chave secreta 071

Assinatura digital com chave pública $\quad 072$

Autenticação Forte $\quad 074$

Processo de pagamento do SET 080

Criptografia de chave com DES e RSA 081

Autenticação com message digest $\quad 082$

Modelo de autenticação SSO 083

Abordagem SSO da Netscape $\quad 084$

O lugar da VPN no modelo ISO 091

VPN intranet 094

VPN Acesso Remoto 095

VPN extranet 095

Implementação englobando os três tipos de VPN 096

Visão de uma implementação de uma VPN para uma EV 100

Disposição das empresas participantes de uma EV com 105

proteção e alguns serviços úteis 


\section{LISTA DE TABELAS}

2.1. Segurança nas etapas do ciclo de uma EV 021

3.1. Possíveis propriedades de agentes 041

4.1. Comparação de gastos entre SAR e VPN

091 


\section{LISTA DE ABREVIATURAS}

(PME's) Pequenas e Médias Empresas

(EV) Empresa Virtual

(SI) Sistema de Informação

(CBIS) Computer-Based Information System

(RC) Rede de Computadores

(IBGE) Instituto Brasileiro de Geografia e Estatística

(PIB) Produto Interno Bruto

(OV) Organização Virtual

(WWW) World Wide Web

(VPN) Virtual Private Network

(VoD) Video on Demand

(NFS) Network File System

(NIS) Network Information System

(UDP) User Datagram Protocol

(TCP) Transfer Control Protocol

(RPC) Remote Procedure Call

(OSI) Open System Interconnection

(DAS) Directory System Agent

(DAP) Directory Access Protocol

(DSP) Directory Service Protocol

(DN) Distinguished Name

(DIT) Directory Information Tree

(RFC) Request For Comments

(LDAP) Lightwight Directory Access Protocol

(DCOM) Distributed Component Object Model

(COM) Component Object Model

(HTTP) Hyper Text Transfer Protocol

(CORBA) Common Object Request Broker Architecture

(OMG) Object Management Group

(ORB) Object Request Broker

(IDL) Interface Definition Language

(IP) Internet Protocol

(MIME) Multipurpose Internet Mail Extensions

(IETF) Internet Engeneering Task Force

(MPEG) Moving Picture Experts Group

(ISO) International Standardization Organization

(IEC) International Electrotechnical Commission

(EDI) Eletronic Data Interchange

(SNMP) Simple Network Management Protocol

(CI) Infra-estrutura de Comunicação

(DES) Data Encryption Standard

(SSL) Secure Socket Layer

(SHTTP) Secure HTTP

(IPv6) IP versão 6 
(SET) Secure Electronic Transation

(SSO) Single Sign On

(DoD) US Departament of Defense

(RSA) Rivlest; Shamir; Adleman

(TLS) Transport Layer Security

(W3C) WWW Consortium

(IPNG) IP New Generation

(IPv4) IP versão 4

(IEEE) Institute of Electrical and Electronic Engeneers

(SIPP) Simple Internet Protocol Plus

(SAR) Servidor de Acesso Remoto

(ICMP) Internet Control Message Protocol

(IGMP) Internet Group Management Protocol

(OSPF) Open Shortest Path First

(BGP) Border Gateway Protocol

(NAT) Network Address Translation

(DDE) Dynamic Data Exchange 


\section{RESUMO}

Pequenas e médias empresas muitas vezes se deparam com oportunidades de negócios interessantes, porém além de suas capacidades de exploração. A possibilidade de uma união temporária que agregue competências para a realização de projetos em parceria levou os empresários a considerarem o conceito de Empresa Virtual (EV).

A EV, por si só, requer gerenciamento de recursos distribuidos entre suas empresas participantes. Esse gerenciamento demanda serviços oferecidos por sistemas de informação que possam ser responsáveis pela organização e distribuição da informação da EV.

Os serviços providos pelos sistemas de informação, apesar de oferecerem facilidades e vantagens, apresentam também pontos de vulnerabilidades por onde a empresa pode ser atacada. É necessário que haja formas de proteção contra esses ataques.

Este trabalho analisa os processos em uma EV, determina seus pontos de fraqueza e propõe um conjunto de recomendações para efetuar transação segura nesse tipo de ambiente. 


\begin{abstract}
Small and middle sized enterprises many times come across with interesting business opportunities, byond their capabilities of exploitation. The possibility of a temporary union that adds up competences to execute joint projects, leads the entrepreneurs to consider the Virtual Enterprise (VE) concept.

The VE, by itself, needs management of resources distributed among their participating enterprises. This management demands services offered by Information Systems (IS) responsible for the $\mathrm{VE}$ information organization and distribution.

Although. the services provided by IS bring facilities and advantages, they present points of vulnerability throught which the enterprises can be attacked.

This work analyses the process in a VE, determines their points of weaknesses and propose a set of recommendation to make secure transaction in this kind of environment.
\end{abstract}


As empresas lutam por uma posição sólida e próspera no mundo dos negócios. Pequenas e médias empresas (PME's) podem encontrar mais dificuldades que as grandes devido às suas potencialidades reduzidas, o que as impede de se comprometerem com projetos mais ambiciosos, e de maiores retornos. Esse tipo de limitação levou à união de diferentes PME's em prol da capacitação e execução de projetos que sozinhas não seriam capazes de realizar. Ao final do projeto as empresas envolvidas podem se dissociar, voltando cada uma a suas atividades normais. A esse conjunto de empresas cooperando entre si e trabalhando em um mesmo projeto dá-se o nome de Empresa Virtual (EV).

Com a união de empresas, diferentes fontes de informação precisam interagir entre si. Para que seja possivel o manuseio da informação de forma organizada, precisa e eficiente, é preciso um bom Sistema de Informação (SI). Um SI é uma série de elementos ou componentes interrelacionados que coletam (entrada), manipulam e armazenam (processo), disseminam (saída) os dados e informações e fornecem um mecanismo de feedback. Um sistema de informação baseado em computador (ou CBIS - computer-based information system) é composto pelo hardware, software, banco de dados, telecomunicações, pessoas e procedimentos, que estão configurados para coletar, manipular, armazenar e processar dados em informação (Stair 1996). Um bom CBIS é capaz de agilizar e melhorar pontos do processo de uma EV, elevando a qualidade de seus trabalhos.

O SI fornece serviços que permitem às empresas gerenciar e compartilhar seus recursos, realizar comunicações, acessar informação de modo eficiente, etc. Esses serviços, entretanto, podem apresentar pontos de vulnerabilidades a serem explorados por intrusos. As telecomunicações abrem caminho para intrusões através das redes de computadores (RC's). Uma EV, tendo várias empresas envolvidas, pode apresentar diferentes pontos vulneráveis em diferentes partes da sua estrutura de redes.

Uma vez que os serviços fornecidos pelos SI's trazem vulnerabilidades aos ambientes, é preciso encontrar os pontos vulneráveis e defendê-los, tornando esses serviços funcionais e sem riscos. 
Assim, podemos enxergar a demanda por um sistema de proteção do ambiente. Uma EV exige proteção para todas as suas participantes, garantindo assim um nível mínimo de segurança para a EV como um todo.

Este trabalho tem por objetivo apresentar uma proposta de um ambiente seguro para EV's, observando características de SI's úteis ao processo e medidas que anulem, ou reduzam, suas vulnerabilidades.

A fim de conseguir fornecer uma base de orientação para aqueles que pretendem fazer suas comunicações de forma segura, nos preocupamos em entender a estrutura das EV's, estudar os serviços de que podem dispor e como podemos torná-los seguros. Como resultado apresentamos um conjunto de opções explicitando medidas que possam ser tomadas pelos envolvidos nesse tipo de empreendimento, e que lhes garantam um nível apropriado de segurança.

O projeto completo é composto por levantamento bibliográfico dos assuntos relevantes ao projeto: o estudo de protocolos de comunicação, técnicas usadas para prover segurança em redes (estudadas para a formação de opiniões com relação a medidas de segurança cabíveis em cada nível de uma Empresa Virtual), protocolos de comunicação seguros, infra-estrutura de informação para trabalho cooperativo, políticas de segurança em ambiente computacional. Como resultado são apresentadas opções para o uso de redes de computadores com segurança no âmbito de Empresas Virtuais, de acordo com o tipo de aplicação envolvida.

Este trabalho está dividido da seguinte forma:

O capítulo 2 faz uma breve introdução sobre Empresas Virtuais, sua origem, suas motivações, sua estrutura, o auxílio que a tecnologia pode lhe prover, e a necessidade por segurança nessa tecnologia.

O capítulo 3 é sobre infraestrutura de informação, que serve de base para a implementação de serviços úteis aos sistemas de informação. São tratados nesse capítulo o gerenciamento de sistemas de arquivos e diretórios (NFS, X.500 e LDAP), gerenciamento de objetos (ActiveX, 
DCOM e CORBA), tecnologias de empacotamento (MIME, MPEG e EDI), gerenciamento de redes (SNMP) e tecnologia de agentes móveis.

O capítulo 4 trata da proteção da informação. Aqui são apresentados o conceito de intrusão - (acesso à sites, interceptação de mensagens), vulnerabilidades dos sistemas (desvio, perda de propriedade intelectual, cópia ilegal, vírus) e contramedidas que auxiliam na sua proteção (criptografia, assinatura digital, certificado digital, política de acesso).

O capitulo 5 apresenta uma proposta de um ambiente para EV's, permitindo que utilizem seus serviços de forma segura. Aqui adaptamos os meios de proteção a esses serviços, evitando possíveis intrusões.

No capitulo 6 são apresentadas as conclusões sobre o trabalho.

Em anexo seguem partes de políticas de segurança vigentes para o ICMC-USP/São Carlos (apêndice A), a UNESP (apêndice C) e a UNICAMP (apêndice B). 


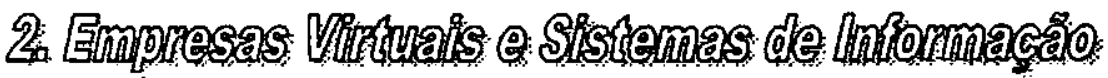

\subsection{Empresas Virtuais}

A realidade tecnológica e econômica traz constantes inovações às empresas no que se refere a seus comportamentos, tanto interna quanto externamente. Várias Pequenas e Médias Empresas (PME's) têm surgido, e devido a sua estruturação, menor e mais flexível que a das grandes empresas, podem atender de forma mais rápida e ágil às necessidades do mercado.

As PME's ocupam uma fatia muito representativa dentro do ambiente econômico total das empresas. Baseado no censo do IBGE (Instituto Brasileiro de Geografia e Estatística) de 1970 observa-se que, já naquela época no Brasil, 97,27\% dos estabelecimentos industriais, 99,9\% dos comerciais e $99,91 \%$ dos prestadores de serviços eram PME's. Os pequenos e médios empreendimentos respondiam por $40 \%$ do PIB (Produto Interno Bruto) brasileiro. Estas empresas respondiam por $80 \%$ das vendas comerciais, $56 \%$ da produção industrial, $71 \%$ da receita de prestação de serviços, $84 \%$ da força de trabalho e $71 \%$ da massa de salários do país. A partir desses dados, e considerando-se que esses números provavelmente tenham ganhado ainda maior peso, desde 1970 até hoje, é possível tirar conclusões sobre a real e grande importância dessas empresas no âmbito econômico e social brasileiro.

As PME's, entretanto, justamente devido à sua estrutura menor e mais flexível, podem se ver, de repente, incapacitadas a atenderem determinadas necessidades de mercado. Esse tipo de problema leva os donos e gerentes dessas PME's a buscarem soluções que possam ajudá-los. $O$ objetivo é poderem, de alguma forma, usar a capacidade de suas empresas para resolver parte do problema que o mercado apresenta e conseguir lucrar com isso. No entanto, o mercado procura empresas que possam suprir toda sua necessidade, e não apenas parte dela. A solução assim encontrada pelas PME's é a parceria entre elas, afim de que esses agrupamentos se tornem capazes de suprir necessidades completas apresentadas pelo mercado. Dessa forma, o mercado é atendido por um grupo de empresas que se comunicam e cooperam entre si. Quem contrata 0 grupo formado pelas PME's não precisa saber quem e quais são elas. O importante é que suas necessidades serão totalmente satisfeitas. 
Os grupos são formados dinamicamente em torno de um objetivo que se torna comum às PME's participantes. Isso significa que o grupo geralmente existe enquanto da realização do objetivo, depois do que se dissolvem, podendo vir ou não a ser formado novamente no futuro. Algumas das PME's envolvidas podem se unir novamente como parceiras em outro grupo formado em torno de outro objetivo com mais ou menos PME's participantes.

Esses grupos formados entre empresas com finalidade de realização de um objetivo global são as chamadas Empresas Virtuais. De acordo com diversos trabalhos na literatura (citados em Bremer 1997), Empresa Virtual (EV) pode ser definida como uma forma de cooperação legal de empresas, pessoas e/ou instituições independentes que formam uma capacidade comum de entendimento sobre um negócio. As unidades cooperantes dividem o trabalho de acordo com suas competências básicas e atuam na geração de ofertas sobre terceiros como unidade básica.

A prática tem mostrado que essa cooperação entre empresas tem encontrado uma crescente aplicação. PME's localizadas em uma mesma região começaram a formar o que é chamado de Organização Virtual (OV). Uma OV reúne parceiros potenciais para uma EV. À medida em que oportunidades que se encaixam no ramo de negócios de uma OV surgem, diferentes EV's são formadas com as empresas participantes a fim de realizarem os trabalhos.

A troca de informação entre as empresas que participam de uma EV é fator fundamental para o sucesso de suas operações. Por isso seu interesse em tecnologias de informação é constante. $O$ crescimento da importância dessa tecnologia sobre toda atividade social é um fato indiscutível e irreversivel. Transferência de dados, informação ou conhecimento tem sofrido com a onda tecnológica uma profunda mudança em sua forma, velocidade e alcance. Esse efeito pode ser certamente benéfico à sociedade em todos os seus componentes (econômico, estratégico, intelectual, cultural) (Schutter 1993).

A informação ficou muito mais acessivel. Existem atualmente muitas facilidades, e muitas outras vem surgindo, no sentido de tornar cada vez mais simples e eficaz o alcance de vários tipos de informação, e é nesse ponto que o uso do computador ajuda bastante. 
A margem entre o uso e o abuso entretanto é bastante estreita. Se a criminalidade relacionada à informação sempre existiu, a intervenção do computador com suas características mencionadas de tempo, volume e alcance pesam para o aumento de risco da atividade criminal.

Uma grande facilidade e utilidade para as EV's são as redes de computadores, através das quais empresas podem procurar parcerias, estudá-las, contatá-las e trocar informações a fim de especificar, negociar, executar e finalizar transações, sem a necessidade de se encontrarem todas no mesmo local físico (Fig. 2.1).

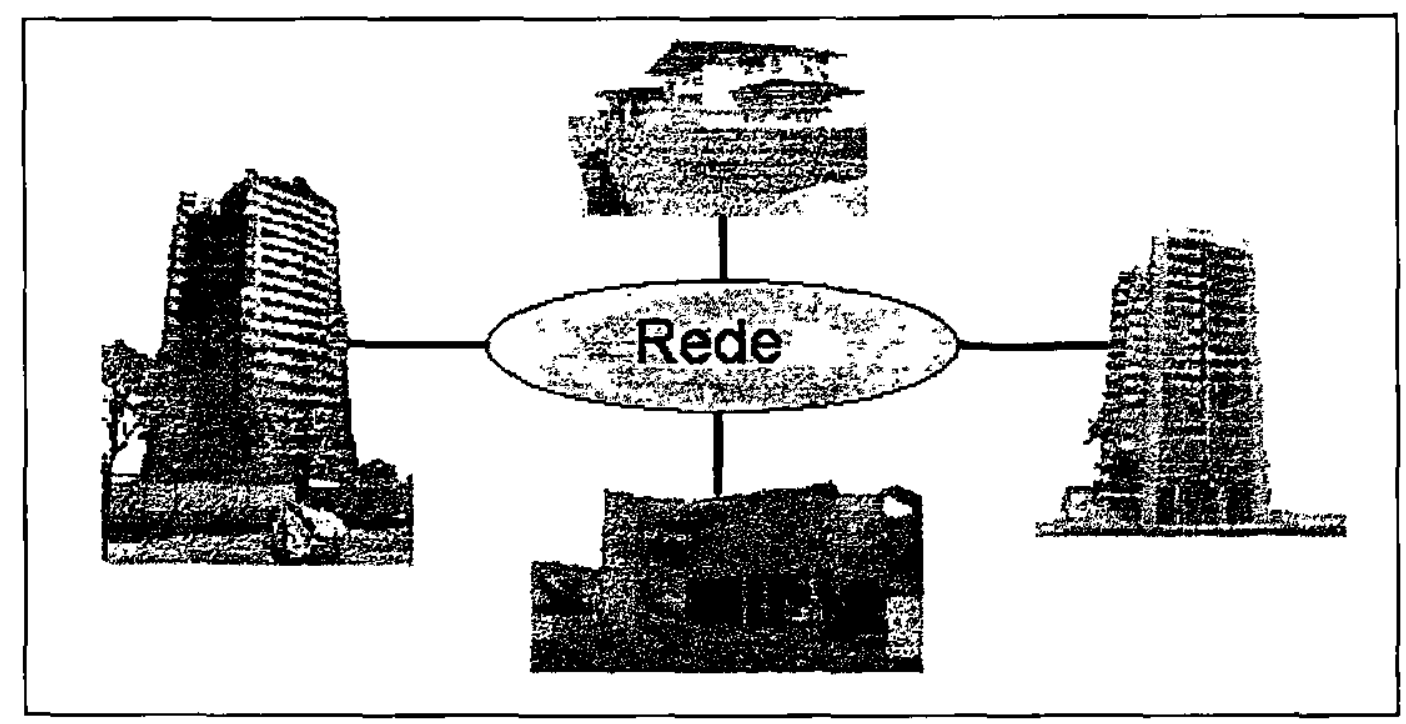

Fig. 2.1 - Intercomunicação para troca de mensagens via rede de computadores (RC)

$>$ Procura -- Com a atual disponibilização de todo tipo de informação através da Internet, torna-se viável e interessante a busca de possíveis parcerias nesse ambiente. Antes da Internet, encontrar parcerias era mais complicado. Agora porém, a utilização de um aplicativo de busca - existem vários disponíveis - pode auxiliar muito nessa operação, apresentando uma lista de op̧̧ões como resultado.

$>$ Análise - Várias empresas, incluindo PME's, disponibilizam informações sobre si na Internet, em geral como forma de marketing de seus produtos ou informações gerais sobre a própria empresa. A partir desses dados uma empresa que está em busca de parceria pode analisar e fazer uma seleção daquelas que se encaixam no perfil que lhe interessa.

$>$ Contato - Depois de feito um estudo preliminar sobre empresas que possam ser interessantes como parceria, é hora de entrar em contato com elas. Esse contato pode ser feito através de 
telefone, fax, cartas ou através da Internet. O primeiro contato pode ser facilmente feito através de e-mails. Nesse ponto é feito um estudo mais aprofundado sobre a empresa em questão, quando se pode obter mais informações.

$>$ Especificação e negociação - Depois de escolhidas as parcerias é hora de especificar o que tem para ser feito e negociar a respeito. Uma facilidade que o uso da rede pode prover nessa etapa é a Vídeo-Conferência, que funciona como uma reunião virtual. Através dela se evita enormes gastos com reuniões, incluindo viagens, hospedagens e alimentação, baixando o número de reuniões tradicionais para o mínimo possível.

$>$ Execução - Durante toda a execução do trabalho é possível a comunicação e cooperação através da rede, usando trocas de mensagens e dados, o que é indispensável para o sucesso do grupo.

$>$ Finalização - A finalização do trabalho, como acertos, pagamentos, conclusões, considerações e dissolução do grupo também pode ser feita via rede.

A Fig. 2.2 representa uma estrutura que descreve os processos de uma empresa virtual dinâmica desde sua criação até sua dissolução.

Com a tecnologia de que dispomos nos é possível tratar a informação com uma série de vantagens sobre os meios utilizados em tempos passados. Usando-se computadores interligados em redes, dados são transmitidos muito mais rapidamente. Assim como o correio eletrônico, qualquer outro tipo de informação enviada através dessa Rede de Computadores apresenta grande velocidade, se comparado com outros meios de transferência.

Por outro lado, o uso da rede citada apresenta também desvantagens. A possibilidade de haver vários computadores conectados à rede faz crescer a probabilidade de mais pessoas terem acesso às informações que nela trafegam. Em certas ocasiões esse pode ser exatamente o objetivo desejado (ex. divulgação de produtos), mas em outras, isso pode representar enormes riscos àqueles que possuem a informação (ex. segredo de planos de indústria, ou segredos nacionais do governo). No segundo caso, quem detém a informação quer segurança no sentido de que ninguém consiga ter acesso à mesma, a não ser que ele autorize. 
Tem acontecido grande corrida no sentido de conseguir garantir segurança na Internet por parte de uns, e de conseguir quebrar todo e qualquer tipo de tentativa nesse sentido, por parte de outros. Empresas, pessoas e até mesmo o governo contratam especialistas para desenvolverem sistemas de proteção para seus dados, ou compram esses sistemas já desenvolvidos no mercado. Muitas outras empresas, pessoas e até mesmo o governo contratam especialistas para violarem essa proteção.

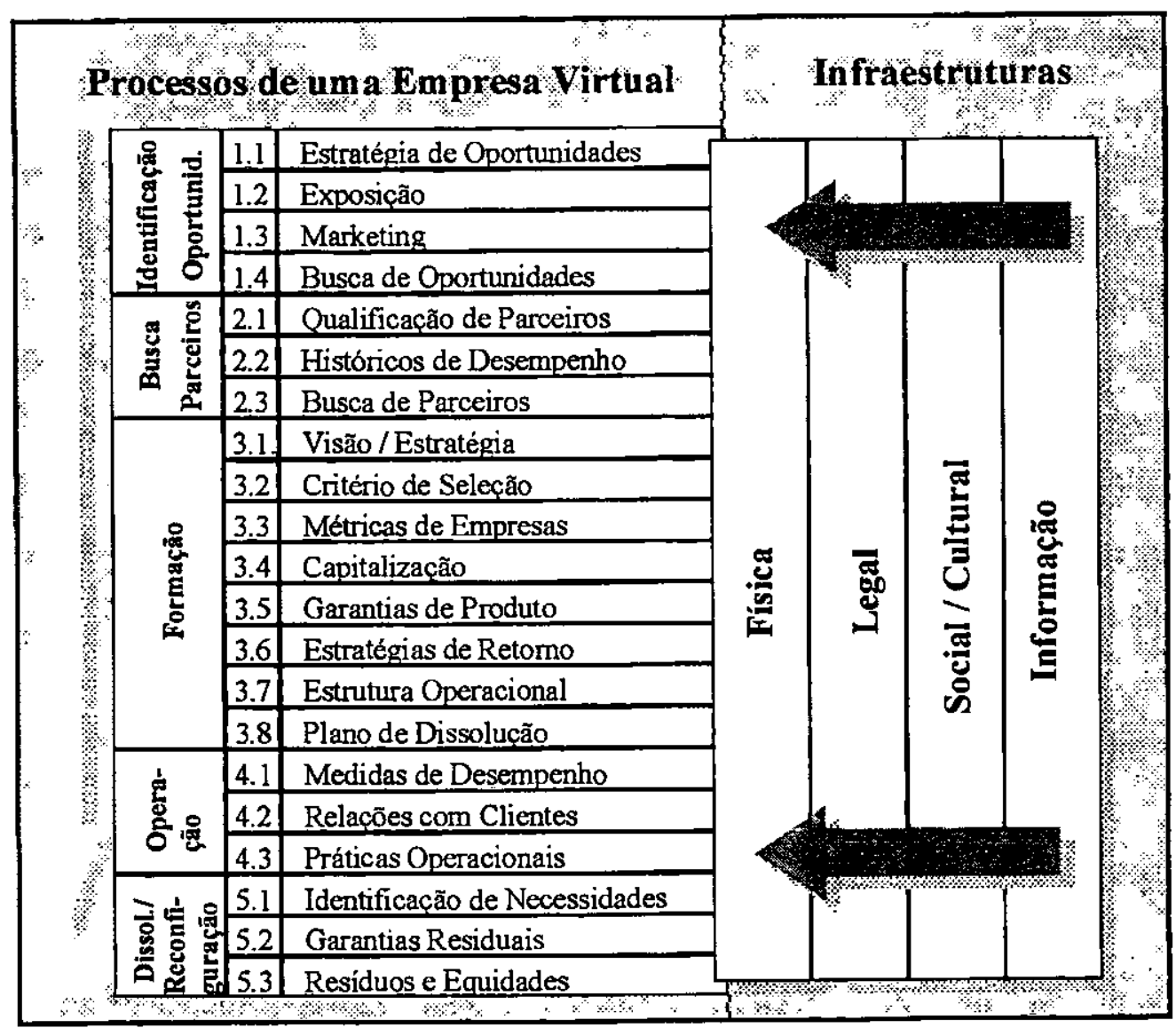

Fig. 2.2 - Estrutura de uma Empresa Virtual Dinâmica (Bremer 1997)

Para muitas empresas é fundamental proteger seus dados do alcance de outras, e para muitas outras se torna bastante interessante ter acesso aos dados da concorrente (Espionagem Industrial). Para o governo, muitas vezes pode ser crucial manter segredo quanto às suas informações, e outros governos podem se interessar em saber o que há de importante escondido ali. Outro interesse que o governo pode apresentar quanto a violar proteções de dados é no caso de descobrir e desmontar grupos como traficantes, terroristas, etc. Além disso, pessoas comuns 
muitas vezes se divertem conseguindo quebrar esse tipo de segurança, tendo acesso a muitas informaçðes que seus proprietários podem não querer que tenham.

Ao utilizar as redes de computadores, os participantes das EV's se vêem diante do grande problema da Segurança da informação. A segurança quanto aos dados na rede em uma empresa pode ser ameaçada de duas maneiras: 1. Intrusão no sistema e conseqüente acesso às bases de dados da empresa, e 2. Interceptação de mensagens durante a troca dessas entre as empresas participantes da EV.

No caso de EV's não se costuma ter um sistema centralizado ao qual um intruso possa invadir e prejudicar a base de dados, mas sim bases de dados particulares a cada empresa participante, eliminando, dessa forma, o risco da invasão à base de dados central. No entanto uma EV se vê muito frágil quanto a seus dados no que diz respeito à interceptações durante comunicações entre suas empresas participantes. Esse tipo de intrusão pode causar sérios danos às EV's e à seus projetos. É importante ressaltar que, mesmo sem uma base de dados centralizada, se houver intrusão e prejuízo ao sistema de uma das empresas participantes, muito provavelmente a EV será afetada como um todo.

\subsection{Demanda por Sistemas de Informação no Processo de uma Empresa Virtual}

\subsubsection{Identificação de Oportunidades}

Algum agente, seja ele uma empresa com capacidade de liderar uma EV ou um grupo de especialistas, se encarrega em identificar, caracterizar e/ou refinar uma oportunidade. Esse agente se torna um corretor (broker) da EV, seja ele interno ou não a ela. Ele vai identificar e refinar a oportunidade, e então definir suas necessidades de exploração e as capacidades da EV.

\subsubsection{Estratégia de oportunidade}

O agente identificador de oportunidades precisa assumir uma estratégia explícita e sensata, sem pontos duvidosos, cujos resultados devem ser compreendidos e adotados pelos membros da EV. É importante porém, quando da divulgação dessa estratégia, evitar a revelação de detalhes sobre a oportunidade para impedir a ação dos competidores. 
Deve ser definida nesse momento o líder, ao menos para essa primeira fase. Esse papel pode ser atribuído a uma empresa participante ou a um especialista em estratégias, como, por exemplo, corretores e consultores. Esse líder utilizará algum método para estabelecer a relação entre os participantes e a oportunidade a partir das competências de cada um.

Visualiza-se então o sucesso do empreendimento e analisa-se a oportunidade verificando se pode ou não ser considerada uma candidata à aplicação do conceito de EV.

Nesta sub-etapa o líder pode-se valer de serviços como o acesso a WWW para estabelecer a relação desejada entre os participantes e estudar as competências de cada um, mesmo sem que eles saibam que estão sendo estudados nesse sentido. Para isso basta que se realize o acesso aos sites de cada potencial participante e se analise seus dados. Aqui se faz útil a proteção contra applets Java e ActiveX, uma vez que os participantes são desconhecidos e não existe ainda a confiança total em seus sites. Da mesma forma é preciso tomar cuidado contra vírus que possam ser trazidos através de downloads desses sites.

Uma vez que o líder não precisa necessariamente estar em seu escritório para realizar esse tipo de operação, ele pode se valer também do serviço de seção remota, esteja ele onde estiver, para alcançar seu provedor.

É importante dizer que em qualquer das sub-etapas que se seguem na qual seja interessante usar os serviços de e-mail, acesso a WWW, acesso a base de dados e serviços de diretório, pode se valer para isso do uso da seção remota, uma vez que, como aqui, não é necessário estar no próprio escritório para utilizar esses serviços.

\subsubsection{Exposição}

$O$ líder, definido no passo anterior (item 2.2.1), informa aos potenciais parceiros a respeito da oportunidade. Aqui ele pode se valer do serviço de e-mail para entrar em contato com as outras empresas, além do serviço de divulgação/marketing, a fim de informá-las e estabelecer uma ligação inicial. As outras empresas certamente estudarão a oportunidade bem como o próprio líder, podendo usar para isso, além de uma interação direta por mail, o acesso ao site com informações sobre o líder e sobre as outras participantes via WWW.

Pode ser útil um sistema de deteç̧ão de intrusão, caso algum dos potenciais parceiros procure invadir para obter mais do que as informações que o líder disponibilizou.

É importante ressaltar também que durante essas etapas de procura de parcerias e formação da EV pode ocorrer o desvio e o líder, por exemplo, acabar acessando um site "pirata". É necessário 
cuidado nesse sentido. Uma solução a esse problema pode estar na exigência de um certificado (conseguido com entidades emissoras de certificados) e no uso de assinaturas digitais nas comunicaçôes com os potenciais parceiros.

\subsubsection{Ação no mercado}

Há determinadas ações a serem tomadas a fim de intervir no mercado e firmar uma oportunidade. Deve haver uma grande interação com o cliente, que, por sua vez, deve ser integrado à EV. O líder da EV, ou alguém especificado para isso, educa o cliente no sentido de ajudar a criar demanda pela oportunidade. Tais ações têm o objetivo de definir melhor as necessidades para exploração da estratégia e ajudar na seleção dos parceiros da EV.

A interação com o cliente pode ocorrer naturalmente através do uso do serviço de e-mails. $\mathrm{O}$ líder pode educar esse cliente de diferentes formas, por exemplo via WWW, através de acessos a sites apropriados, com informações via mails, usando o serviço de video-sob-demanda ou ainda através do serviço de divulgação/marketing.

\subsubsection{Procura de oportunidade}

As oportunidades nem sempre estão totalmente explícitas. Cada participante de uma EV deve estar sempre atento e a procura de novas oportunidades nas quais possa participar de acordo com suas capacidades, sejam elas com a mesma EV que estiver atuando ou não. Caso novas oportunidades surjam, porém não compatíveis com os atuais parceiros, novas parcerias podem ser feitas para explorá-la, formando assim uma coleção de processos diferentes dependendo da área e da criatividade dos participantes.

A procura por novas oportunidades pode se dar através de buscas e observações na WWW, ou contato direto com empresas que trabalham nos ramos de interesse. No último caso pode-se conseguir esse contato também através do serviço de e-mail.

Nesse passo é importante ressaltar que as participantes, ao procurarem as oportunidades, devem tomar cuidado com applets Java, ActiveX hostis e virus transmitidos pela rede. Se infectadas, além de prejudicarem seus próprios sistemas, pode estar também contribuindo para a infecção de toda a EV.

\subsubsection{Seleção}


Aqui é feita a seleção de parceiros. Esses processos podem ser realizados em conjunto com a identificação das oportunidades, reduzindo assim os custos. Porém as decisões de negócio normalmente são associadas primeiro à identificação de uma oportunidade, e então à formação das parcerias para sua exploração.

\subsubsection{Qualificação dos parceiros}

Deve-se determinar as principais competências dos potenciais parceiros através de um método padrão envolvendo questões técnicas, de qualidade, capacidade e critérios financeiros. E devem ser definidas também as competências necessárias para a exploração da oportunidade, de modo que possam ser identificadas nas competências dos potenciais parceiros.

A identificação das competências de cada possível parceiro pode ser realizada através de visitas e estudos de suas páginas na WWW, se essas páginas forem suficientemente elucidativas. Se o material que as empresas disponibilizaram na Web não bastar, pode-se buscar então através de outros sites que contenham referências sobre elas, ou ainda através de correspondência direta via mail.

Mais uma vez pode ser usado o acesso à WWW e seus serviços, e deve-se manter o cuidado com applets Java, ActiveX hostis e virus.

\subsubsection{História dos parceiros}

Em uma EV é essencial que exista a confiança entre os parceiros, sem a qual o seu funcionamento fica praticamente impossível. Neste passo o intuito é avaliar, com o uso de sistemas métricos, o desempenho passado dos possíveis parceiros. O processo explicitado no item anterior (2.2.2.1.) avalia a qualificação usando diferentes estratégias, mas esse se baseia em informações históricas. Para que os dados possam ser melhor analisados é importante que se tenha ferramentas que possam proporcionar um mapeamento de casos passados para casos atuais, uma vez que em muitas ocasiões as condições atuais se podem se apresentar bastante diferenciadas das anteriores.

É comum as empresas divulgarem em suas páginas na WWW nomes de clientes que já usaram seus serviços, e em alguns casos até mesmo os nomes dos projetos que desenvolveram. Dessa forma pode-se procurar saber mais sobre os projetos, usando para isso a própria WWW, ou mesmo entrar em contato com os clientes citados através do serviço de $e$-mail e saber a opinião que eles têm a respeito de tais empresas. 
Nessa etapa a confiança quanto a integridade do parceiro e aos seus sites já deve ter sido alcançada. Se for verdade os cuidados com applets Java e ActiveX hostis já não se fazem tão necessários, considerando que o parceiro não colocaria tais elementos em seus sites.

Vírus entretanto é sempre um perigo à parte, pois alguém pode transmiti-lo inconscientemente através de um arquivo infectado sem seu conhecimento. É sempre bom verificar essa possibilidade em uma troca de dados pela Internet.

\subsubsection{Procura dos parceiros}

É bastante comum a procura exaustiva por parceiros a fim de se formar uma EV. O ideal seria a existência de vários métodos de procura de possíveis candidatos a parceiros, que poderia ser usado pela empresa líder, ou o corretor, da EV.

Um desses métodos pode ser a busca na WWW. Existem mecanismos de busca onde pode-se especificar o assunto pertinente e vários links são mostrados. Entre esses links pode haver desde definições sobre tal assunto até empresas que trabalhem com ele.

\subsubsection{Formação}

Uma vez que a oportunidade e os parceiros foram encontrados, o caso de negócio deve ser criado, e com ele devem ser estabelecidos os compromissos requeridos entre os parceiros. Há cuidados importantes a serem tomados nessa fase para garantir o sucesso das etapas seguintes (operação e dissolução) da EV.

\subsubsection{Desenvolvimento da estratégia e visão}

Desde o início da formação da EV deve haver uma declaração de propósitos bastante explícita. A estratégia se baseia em uma missão, normalmente diferindo bastante das estratégias próprias de cada participante, de acordo com uma infra-estrutura temporária. A estratégia criada deve incluir todo o ciclo de vida da $\mathrm{EV}$, além de respostas a possíveis mudanças, sejam elas esperadas ou não, e deve ser compartilhada entre os participantes Esse compartilhamento pode acontecer sem problemas através de mails ou do serviço de divulgação/marketing. Como envolve comunicação através da Internet, o cuidado com virus se faz importante. 


\subsubsection{Critérios de seleção e parceria}

Essa é a parte onde é realizado o comprometimento real entre os parceiros. Entretanto, possivelmente aqui isso já estará em estado avançado decorrente das etapas anteriores. É importante então, que haja uma coleção de processos que possam servir para esclarecimento de todos os papéis na EV determinando os pontos obscuros. Dessa forma se durante todo o periodo de existência da $\mathrm{EV}$, ou ainda posterior a isso, alguém quiser ou precisar de informação a esse respeito, existirá onde recorrer.

O serviço responsável pela troca de documentos pode ser bastante útil aqui, e também o cuidado com vírus, uma vez que, como dito acima, pode ser transmitido inconscientemente, nesse caso como macro de documentos, por exemplo.

Este é um momento bastante propício para a ocorrência de reuniões entre os parceiros. E assim como eles podem se valer do serviço de e-mail para se comunicarem, para realizarem uma reunião podem usar o serviço de videoconferência, ou mesmo foneconferência. Dessa forma evitam gastos desnecessários para realizar um processo extremamente importante, que é a reunião.

A videoconferência apresenta caracteristicas diferentes da foneconferência, e cabe a cada EV determinar aquela que melhor se aplica ao seu caso baseando-se em diversos fatores como tecnológico, cultural e financeiro. De qualquer forma seria interessante que esses serviços pudessem oferecer proteção como criptografia na transmissão (o que é feito no caso de uma VPN), para evitar espionagem nas reuniões.

\subsubsection{Métricas da empresa}

Dentro da formação da EV é importante determinar as métricas aplicáveis a ela, baseando-se em métricas operacionais e financeiras tradicionais. Essas métricas têm a finalidade de proporcionar a identificação de possiveis alterações nos rumos da EV. Com elas pode-se definir se as metas principais da EV estão sendo alcançadas ou não, e também determinar possíveis problemas e/ou modificações futuras. Dessa forma a determinação das métricas da EV se faz imprescindível para a análise do andamento da mesma ao longo da execução do projeto.

Essa é uma parte importante da EV e é o que possibilitará a disponibilização do serviço de auditoria. 


\subsubsection{Capitalização}

Nessa etapa deve ser criada uma nova infra-estrutura legal/financeira na qual fica bem determinado quem contribui com quais capitais (ou bens) e o compromisso desses. Pode existir ainda a necessidade de uma metodologia para avaliar o aspecto de propriedades intelectuais.

Este é outro ponto onde uma reunião muito provavelmente se torna necessária, podendo a empresa novamente fazer uso do serviço de videoconferência e/ou foneconferência e troca de documentos, ficando atenta para proteções contra espionagem (criptografia) e vírus.

\subsubsection{Responsabilidade sobre os produtos}

Este é o momento em que as responsabilidades são atribuídas dentro da EV. Todo e qualquer tipo de responsabilidade possivel deve ser indicada e ter a quem ser atribuida, inclusive as mais improváveis. Isso é feito nesse processo a partir de uma infra-estrutura legal que estabelece quais as responsabilidades de cada participante, e de que forma o cliente estará garantido, não se referindo unicamente ao produto, mas também a questões sociais, ecológicas e outras.

Assim como na etapa anterior aqui a vídeo/foneconferência podem ser úteis na realização de uma reunião, o que é imprescindivel para a determinação de tais responsabilidades.

Uma vez definidas as responsabilidades, os dados a esse respeito devem ser distribuídos entre os participantes, o que pode acontecer usando o serviço de troca de documentos. É importante entretanto garantir a segurança a esses documentos, de forma que não possam ser alterados, assim como é desejado toda vez que se utiliza esse serviço, bem como os serviços de diretório e os acessos a eles.

A proteção às transmissões é de grande importância aqui, e o cuidado com virus mais uma vez é necessário.

\subsubsection{Estratégias de recompensa/riscos}

Um outro ponto a ser analisado é o ponto referente a riscos e recompensas. Acima temos citadas duas etapas baseadas em compromissos contratuais, o que propõe a especificação em detalhes de recompensas e riscos, sendo o primeiro baseado no segundo (recompensas baseadas em riscos).

Os riscos pertinentes ao processo como um todo servem de métrica para a EV, e devem ser estabelecidos durante o processo de métricas da empresa. 
Embora bastante comum, é bom ressaltar que os riscos nem sempre implicam em aspectos monetários. Há outros tipos de riscos colocando em jogo aspectos diferentes, como por exemplo nome e imagem.

\subsubsection{Estruturas operacionais}

A função a ser realizada aqui é a de criação de uma infra-estrutura operacional para a EV. O relacionamento entre os parceiros devem se apoiar nessa infra-estrutura. Deve-se também determinar os agentes responsáveis pela administração da EV, apresentar a hierarquia dos parceiros de forma clara e estabelecer as relações de reportagem e supervisão, onde pode ser usado o serviço de auditoria.

Essa estrutura é a base das comunicações e troca de dados entre os parceiros. Ela deve ser segura e eficiente. Através dela se darão os mails, as videoconferências, foneconferências, video-sobdemanda, acessos à base de dados e aos serviços de diretório, e troca de documentos.

Aqui é o principal ponto de estudo dos serviços disponiveis, suas vulnerabilidades e as proteções aplicáveis à estrutura da EV.

\subsubsection{Plano de dissolução}

Uma vez que as EV's são formadas em torno de uma oportunidade temporária, é natural e necessário que seja planejada também a sua dissolução. $O$ plano para essa dissolução, bem como a infra-estrutura para que seja realizada, devem ser criados juntamente com a criação da EV.

Para que a dissolução possa ser determinada no momento certo deve-se estabelecer e criar algum tipo de gatilho que dispare tal ação. Assim que esse gatilho for acionado o processo de dissolução tem início e todos os participantes são informados disso, por exemplo via mail. Essa informação, entretanto, deve funcionar para os participantes apenas como confirmação do início de tal processo, uma vez que todos já devem estar cientes e de acordo para que seja realizado. Tal informação precisa ser confiável, pois alguém pode querer sabotar a EV e transmitir o disparo do gatilho, sem que ele tenha sido realmente disparado pelo responsável. Assinatura Digital é uma boa forma de se evitar isso.

\subsubsection{Operação}


Durante toda a operação observadores externos devem enxergar a EV como uma organização única. Embora existam provavelmente caracteristicas que são únicas na operação de EV's, existem também muitas características similares, ou mesmo idênticas, àquelas de grandes empresas descentralizadas.

\subsubsection{Medidas de desempenho}

Deve haver métricas que possam ser usadas para medir o desempenho da EV, individualmente em micro nivel (mais baixo nível de interesse da estratégia da EV) e para os níveis macro da EV como um todo. Essas métricas servem como ajuda à estrutura de risco e recompensa.

$\mathrm{O}$ ideal é que tais medidas de desempenho possam ser observadas a qualquer momento. Uma forma de realizar essas observações é através de aplicativos pela rede, ou mesmo com a comunicação entre os participantes. O serviço de e-mail pode ser aplicado para essas comunicações e o serviço de auditoria servirá para a análise dessas medidas.

Os dados usados aqui precisam ser corretos. Para evitar sabotagens através de intrusões ativas pode-se usar assinatura digital.

\subsubsection{Relações com os clientes}

Os clientes enxergam a empresa como uma organização única, ficando toda a estrutura real da EV transparente a eles. Os clientes precisam de uma organização que seja capaz de realizar a tarefa desejada, e é exatamente isso que eles vêem.

As métricas devem medir as estruturas de risco e remuneração, sendo algumas delas baseadas na satisfação do cliente, e essa satisfação é conhecida através do contato direto com ele. Para tanto um representante da empresa, que pode ser ou não o líder, precisa conversar com esse cliente, o que pode ser feito pessoalmente, através de troca de mails, por telefone ou ainda por uma videoconferência. O vídeo sob demanda e o serviço de divulgação/marketing podem ser usados para apresentação de idéias, etapas do projeto ou ainda marketing, ao cliente.

\subsubsection{Práticas operacionais}

Uma vez que a EV entrou em funcionamento, as barreiras existentes entre os participantes devem ser reduzidas ao mínimo, de forma a constituir o mais próximo possível de uma organização única. 
Baixar essas barreiras implica em proporcionar aos participantes condições para grande intercomunicação e interatividade, permitindo a eles os serviços básicos (ver capítulo 5) de forma segura e eficiente com as estruturas operacionais.

\subsubsection{Dissolução/Reconfiguração}

Existe um ponto no ciclo de vida da $\mathrm{EV}$, determinado "a priori" pelos mecanismos métricos, no qual ela deve ser dissolvida ou reformulada. Nessa ocasião a oportunidade deve já ter sido explorada ou terá se alterado.

\subsubsection{Identificação de necessidades}

Já no momento da análise e definição da oportunidade, durante a formação da EV, é determinado um ponto de finalização para ela. Deve haver então um processo com a função de monitorar esse ponto. Tal processo é responsável por identificar o momento em que deve-se revisar a formação da EV, em alguns casos a partir de métricas especiais. Mudanças fundamentais na natureza e estrutura da $\mathrm{EV}$ devem acontecer a partir dessas métricas.

O processo que identificará o momento exato da finalização pode ser de diferentes tipos. Um exemplo é um aplicativo automatizado que verifica o projeto o tempo todo em cada participante através da rede e avisa quando chegado o momento. Outro exemplo é um participante estar sempre analisando o andamento do projeto até o momento em que as condições estabelecidas para a determinação de sua finalização aconteçam. Nesse último exemplo o participante em questão pode fazer visitas aos outros participantes ou simplesmente manter contato com eles via mail, telefone ou vídeo.

É de vital importância para o sucesso da EV que as informações fornecidas a esse processo sejam verdadeiras. Deve-se então evitar sabotagens. No caso de visitas pessoais aos participantes essa sabotagem nas informações se tornam mais difíceis, uma vez que a informação é pega diretamente na fonte, mas no caso de envio de informações eletronicamente, o uso de assinatura digital é bastante útil, além dos tradicionais cuidados contra vírus.

\subsubsection{Responsabilidades residuais}

Ao final do processo da $\mathrm{EV}$, tendo ela sido dissolvida ou reconstruida, deve-se fazer a atribuição de responsabilidades residuais, tais como garantias aos clientes, beneficios trabalhistas e 
responsabilidades sobre os produtos. É possivel atribuir essas responsabilidades a um agente não participante da EV, ou que esse seja um novo participante com um novo papel.

Aqui novamente se faz bastante útil uma reunião entre os participantes. Uma vez mais pode se utilizar dos serviços de troca de documentos e fone/videoconferência para evitar um alto custo com essas reuniões. Vale lembrar que em todos os casos em que esses serviços de conferência são usados, o serviço de e-mail muito provavelmente também o terá sido no processo de agendamento de tais conferências.

\subsubsection{Dispersão equânime de bens}

A fim de distribuir os bens de forma equânime, é necessária uma série de processos com o objetivo de determinar métricas que possam claramente quantificar os ganhos tangíveis e intangíveis.

Esses processos farão uma série de avaliações sobre as empresas participantes e sobre suas participações ao longo de todo o projeto. A rede pode ser utilizada para a realização dessas avaliações e para a divulgação do resultado, bem como a distribuição de alguns bens (ex. transferências bancárias).

O cuidado com intrusões deve ser extremo nessa etapa.

As etapas expostas aqui descrevem todo o processo de uma EV do principio ao fim. É importante ressaltar, entretanto, que não se fazem todas obrigatórias ou rigidas no que diz respeito ao seu seguimento. Durante o processo de concepção, existência e dissolução de uma EV, pode-se notar que algumas dessas etapas não foram incluídas, foram incluidas em ordem diferente, ou ainda apesar de incluidas não foram seguidas exatamente como estão expostas neste trabalho. Levando isso em consideração, foi proposto um framework alternativo em (Bremer et. al. 1998). A descrição das etapas que aqui são apresentadas serve como um guia do que deve ser levado em conta no processo de tratamento de uma EV, tentando ajudar no trabalho de quem pretende realizá-lo. O resumo das etapas citadas, dos serviços úteis e dos cuidados pertinentes é apresentado na tabela 2.1 . 


\begin{tabular}{|c|c|c|c|}
\hline \multicolumn{4}{|c|}{ Segurança nas etapas do ciclo de uma Empresa Virtual } \\
\hline $\begin{array}{c}\text { etapa } \\
\end{array}$ & sub-etapa & Serviços úteis & medidas de seguranca \\
\hline \multirow{4}{*}{$\begin{array}{l}\text { DDENTIFICA- } \\
\text { ÇÃO DE } \\
\text { OPORTUNI- } \\
\text { DADES }\end{array}$} & $\begin{array}{l}\text { Estratégia para } \\
\text { oportunidade }\end{array}$ & $\begin{array}{c}\text { acesso WWW, } \\
\text { seção remota }\end{array}$ & $\begin{array}{l}\text { proteção contra applets Java } \\
\text { e ActiveX hostis, e vírus. }\end{array}$ \\
\hline & Exposição & $\begin{array}{l}\text { e-mail, acesso WWW, } \\
\text { divulgação/marketing }\end{array}$ & $\begin{array}{l}\text { sistema de deteção de } \\
\text { intrusão, certificado, } \\
\text { assinatura digital }\end{array}$ \\
\hline & Ação no mercado & $\begin{array}{l}\text { e-mail, acesso WWW, } \\
\text { divulgação/marketing, } \\
\text { vídeo-sob-demanda }\end{array}$ & $\begin{array}{l}\text { certificado e assinatura } \\
\text { digital }\end{array}$ \\
\hline & Procura de oportunidade & $\begin{array}{c}\text { e-mail, } \\
\text { acesso WWW }\end{array}$ & $\begin{array}{l}\text { proteção contra applets Java } \\
\text { e ActiveX hostis, e vírus }\end{array}$ \\
\hline \multirow[t]{3}{*}{ SELEÇÃO } & $\begin{array}{l}\text { Qualificação dos } \\
\text { parceiros }\end{array}$ & $\begin{array}{c}\text { e-mail, } \\
\text { acesso WWW }\end{array}$ & $\begin{array}{l}\text { proteção contra applets Java } \\
\text { e ActiveX hostis, e virus }\end{array}$ \\
\hline & História dos parceiros & $\begin{array}{c}\text { e-mail, } \\
\text { acesso WWW }\end{array}$ & proteção contra vírus \\
\hline & Procura dos parceiros & Acesso WWW & $\begin{array}{l}\text { proteção contra applets Java } \\
\text { e ActiveX hostis }\end{array}$ \\
\hline \multirow[t]{8}{*}{ FORMAÇÃO } & $\begin{array}{l}\text { Desenvolvimento da } \\
\text { estratégia e visão }\end{array}$ & $\begin{array}{c}\text { e-mail, } \\
\text { divulgação/marketing }\end{array}$ & proteção contra vírus \\
\hline & $\begin{array}{l}\text { Critérios de seleção e } \\
\text { parceria }\end{array}$ & $\begin{array}{l}\text { e-mail, troca de } \\
\text { documentos, } \\
\text { videoconferência, fone- } \\
\text { conferência }\end{array}$ & proteçāo contra vírus, VPN \\
\hline & Métricas da empresa & Videoconferência & VPN \\
\hline & Capitalização & $\begin{array}{l}\text { troca de documentos, } \\
\text { videoconferência, fone- } \\
\text { conferência }\end{array}$ & proteção contra virus, VPN \\
\hline & $\begin{array}{l}\text { Responsabilidades sobre } \\
\text { os produtos }\end{array}$ & $\begin{array}{l}\text { troca de documentos, } \\
\text { videoconferência, fone- } \\
\text { conferência }\end{array}$ & proteção contra vírus, VPN \\
\hline & $\begin{array}{l}\text { Estratégias de } \\
\text { recompensas/riscos }\end{array}$ & $\begin{array}{c}\text { troca de documentos, } \\
\text { videoconferência, fone- } \\
\text { conferência }\end{array}$ & proteção contra vírus, VPN \\
\hline & Estruturas operacionais & $\begin{array}{l}\text { e-mail, acesso WWW, troca } \\
\text { de documentos. } \\
\text { videoconferência, fone- } \\
\text { conferência, video-sob- } \\
\text { demanda, acesso base de } \\
\text { dados e serviços de } \\
\text { diretório } \\
\end{array}$ & proteção contra virus, VPN \\
\hline & Plano de dissolução & e-mail & assinatura digital \\
\hline \multirow[t]{3}{*}{ OPERAÇÃO } & Medidas de desempenho & e-mail, auditoria & assinatura digital \\
\hline & $\begin{array}{l}\text { Relações com os } \\
\text { clientes }\end{array}$ & $\begin{array}{c}\text { e-mail, } \\
\text { divulgação/marketing, } \\
\text { videoconferência }\end{array}$ & VPN \\
\hline & Práticas operacionais & $\begin{array}{l}\text { envolve todos os serviços } \\
\text { citados }\end{array}$ & $\begin{array}{l}\text { emolve todas as medidas } \\
\text { citadas }\end{array}$ \\
\hline \multirow{3}{*}{$\begin{array}{l}\text { DISSOLU- } \\
\text { ÇÄO/RECON- } \\
\text { FIGURAÇȦO }\end{array}$} & $\begin{array}{l}\text { Identificação de } \\
\text { necessidades }\end{array}$ & e-mail & $\begin{array}{l}\text { proteção contra vírus, } \\
\text { assinatura digital }\end{array}$ \\
\hline & $\begin{array}{l}\text { Responsabilidades } \\
\text { residuais }\end{array}$ & $\begin{array}{l}\text { e-mail, troca de } \\
\text { documentos, } \\
\text { videoconferência, fone- } \\
\text { conferência }\end{array}$ & proteção contra vírus, VPN \\
\hline & Dispersão equa. de bens & transferência bancária & certificado, assinatura digital \\
\hline
\end{tabular}

Tabela 2.1. Segurança nas etapas do ciclo de uma Empresa Virtual 


\section{Sumário}

Muitas pequenas e médias empresas vêm surgindo e se fixando no mercado, tornando-se responsáveis por grande número de empregos e boa parte da produção e das vendas realizadas atualmente. Esse tipo de empresa possui estrutura flexível e ágil, beneficiando seu funcionamento e seu trabalho. Por outro lado não são capazes de realizar projetos muito grandes. Uma solução encontrada por alguns empresários foi unir mais de uma empresa em função da realização de projetos que, sozinhas, não seriam capazes de assumir. Surgiu então a Empresa Virtual, que agnupa mais de uma empresa em torno da exploração de uma oportunidade de negócio de interesse das participantes, onde cada uma delas se responsabiliza por parte do projeto, e ao final do qual elas se dissociam.

Assim como em toda empresa, mesmo as pequenas e médias, em uma Empresa Virtual informações devem ser adquiridas, estudadas, analisadas, armazenadas e distribuídas entre seus participantes. $\mathrm{O}$ uso do computador trouxe muitas facilidades às organizações, e a comunicação através das redes de computadores agilizou muitos processos dentro delas. Um bom Sistema de Informação é de grande valor nesse contexto, podendo auxiliar essas empresas em todas as suas subdivisões (ou, em particular para o caso de uma EV, suas empresas participantes) e nas diferentes etapas dos projetos que ela possui. Esse sistema de informação deve ter o conceito da segurança da informação que controla adequadamente trabalhado.

A EV possui um ciclo de vida no qual diferentes etapas são definidas. Cada uma dessas etapas apresenta características próprias, bem como necessidades quanto aos sistemas de informação. Tais sistemas devem poder prover serviços que supram essas necessidades. Neste capítulo citamos, em conjunto com as etapas de uma EV, os serviços que lhes podem ser úteis, em diferentes circunstâncias, e os cuidados a serem tomados. 
Para possibilitar os serviços citados no capítulo 3 é necessária uma infra-estrutura que possa lhes servir de base. Tal infra-estrutura deve incluir gerenciamento de sistemas de arquivos e diretórios (ex. NFS, X500 e LDAP), gerenciamento de objetos (ex. ActiveX, DCOM e CORBA), tecnologias de empacotamento (ex. MIME, MPEG e EDI), gerenciamento de redes (ex. SNMP) e tecnologia de agentes móveis. A seguir trataremos melhor esses termos.

\subsection{Gerenciamento de Sistemas de Arquivos e Diretórios}

Atuaimente é importante para as organizações o trabalho colaborativo. Nesse tipo de trabalho, diferentes partes das empresas podem trabalhar de modo diferente uma das outras, e, ainda assim, precisam trocar informações sobre seus trabalhos, colaborando entre si. Entretanto os dados de cada parte pode ser organizado de modo particular quanto à sua estrutura e localização. Os sistemas de arquivos e diretórios são utilizados no armazenamento e manuseio das informações, oferecendo facilidades para que os funcionários possam tratá-las eficientemente.

\subsubsection{NFS}

NFS (Network File System) satisfaz a necessidade das empresas por um sistema de arquivos global e compartilhado. Suporta grupos de trabalho globais mantendo o sistema de arquivos localizado de forma distribuída e com acesso transparente aos usuários. Apresenta escalabilidade, podendo ser usado em ambientes pequenos a grandes. Funciona sobre uma arquitetura de segurança flexível e extensível, permitindo ao administrador escolher a solução de segurança que se adapta ao seu ambiente atual e ter mais opções no futuro. Oferece facilidade para sua administração de forma centralizada. Para missões críticas é provida uma implementação com alta disponibilidade. Tudo isso, unido à grande variedade de produtos NFS de diferentes vendedores o reafirmam como uma grande opção para a integração de empresas heterogêneas hoje e no futuro. 
O NFS emprega uma arquitetura cliente/servidor e consiste de um programa clientes, um programa servidor e um protocolo usado para a comunicação através da rede. O servidor NFS permite o acesso do sistema de arquivos do seu disco a outras máquinas na rede, através de um processo chamado "exportação". Os diretórios tornados disponiveis são referidos como sistemas de arquivos exportados. O Cliente NFS, por sua vez, ganha acesso aos arquivos do servidor usando um processo chamado "montagem". O cliente NFS monta os sistemas de arquivos exportados do servidor, o que resulta na integração do sistema de arquivos remoto à árvore do sistema de arquivo do cliente (figura 3.1). Um serviço incluido no lado do cliente chamado automounter monta e desmonta sistemas de arquivos na base de forma automática e transparente. $\mathrm{Na}$ visão do usuário, é criado um ambiente onde os sistema de arquivos do servidor está continuamente acessivel (Sun 1995).

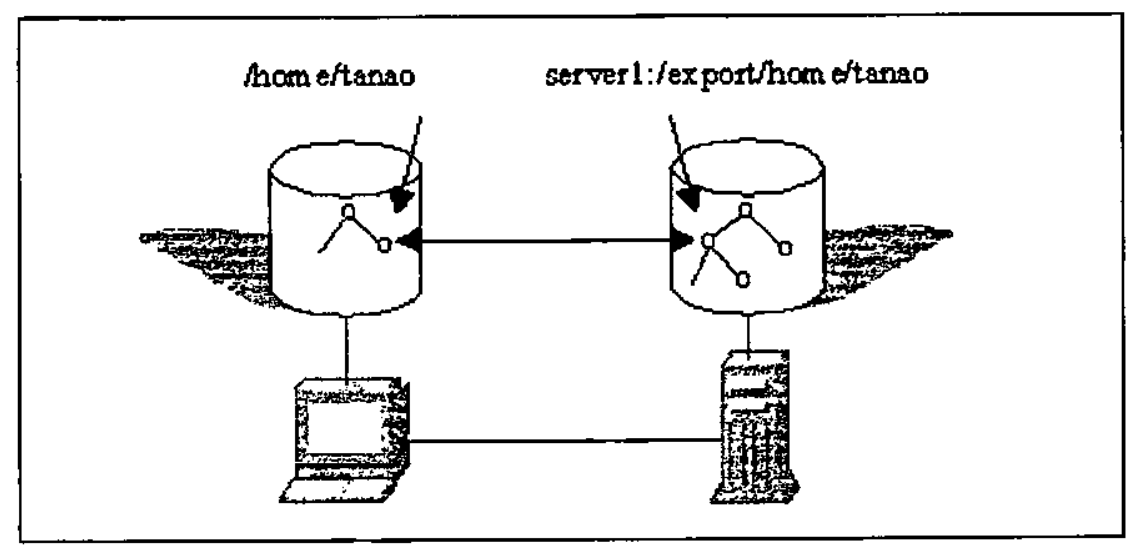

Figura 3.1. Como um sistema remoto é incorporado à árvore do sistema de arquivos do cliente (Sun 1995).

A fim de exportar um sistema de arquivos, o sistema administrador deve editar um arquivo de configuração e especificar:

- O caminho completo do diretório a ser exportado;

- As máquinas clientes que terão acesso ao diretório exportado;

- Qualquer restrição de acesso.

Para que o automounter possa montar um sistema de arquivos ele precisa de um "mapa" que lhe diga o que fazer. O mapa associa um nome de caminho $n$ do cliente com um sistema de arquivos que reside no servidor remoto. Esses nomes de caminho do cliente são também conhecidos por 
mounts ou mount points porque representam pontos do sistema de arquivos do servidor que será montado. Para reduzir tempo e esforço da administração do NFS os mapas são armazenados e administrados de forma centralizada em um serviço de nomes (ex. no sistema SOLARIS os mapas podem ficar armazenados no NIS - Network Information System).

O protocolo NFS possui um conjunto de procedimentos remotos que permite ao cliente manipular arquivos e diretórios no sistema do servidor como se fossem locais. Através das rotinas desse protocolo, clientes enviam requisições para operações de arquivos aos servidores, e esses respondem efetuando a operação (se o cliente tiver permissão apropriada) e enviando de volta os resultados com sucesso ou valores de erro.

NFS é independente de protocolo de transporte, podendo rodar sobre múltiplos protocolos existentes atualmente (ex. UDP e TCP) e com capacidade de rodar sobre novos protocolos no futuro. Essa liberdade se dá devido ao fato de ter sido desenvolvido no topo da tecnologia de chamada de procedimento remoto independente desenvolvida pela Sun (TI-RPC). Todos os procedimentos NFS são implementados como chamadas de procedimento remoto baseadas em TI-RPC.

\subsection{2. $X .500$}

X.500 é um protocolo OSI (Open System Interconnection) que especifica um modelo para conectar serviços de diretório locais a fim de formar um diretório global distribuído (Macquarie 1995). Bases de Dados locais mantêm partes da base global e a informação do diretório é tornada disponível ao usuário via um servidor local chamado Agente de Sistema de Diretório (DAS Directory System Agent). X.500 suporta ainda funções de gerenciamento de dados (ex. adição, modificação e exclusão).

É um padrão que define protocolos e modelos de informação para serviços de diretório independentes de aplicação computacional e plataforma de rede, lançado inicialmente em $1988 \mathrm{e}$ incrementado em 1993 e 1997 (Data Connection). A princípio, o padrão especifica como aplicações do usuário acessa a informação do diretório (DAP - Director Access Protocol), e 
especifica o protocolo usado para propagar requerimento de diretório do usuário entre servidores de diretório quando tal requerimento não pode ser satisfeito pelo servidor de diretório local (DSP - Directory Service Protocol).

Cada item no X.500 descreve um objeto (ex. uma pessoa, uma fonte da rede, uma organização, etc.) e tem um identificador único chamado Nome Diferenciado (DN - Distinguished Name). A entrada consiste de uma coleção de atributos (ex. para uma pessoa seria o último nome, nome da organização, endereço e-mail). As entradas são encontradas navegando através de uma árvore de informação de diretório (DIT - Directory Information Tree). No topo da árvore está o mundo, subdividido ao próximo nível em países, e ao próximo em organizações. Informações sobre pessoas, recursos, etc., é armazenado dentro das organizações.

O design do diretório X.500 é adequado para armazenar informações de pessoas, organizações e outras entidades (ou objetos) como recursos de rede, aplicações ou hardware. Vários projetos utilizam suas capacidades de diretório (ex. os RFC's - Request for Comments - na Internet estão listados no diretório global).

\subsection{3. $L D A P$}

Existe grande interesse, comentário e especulação sobre serviços de diretório. O LDAP é um padrão da Internet para prover um protocolo leve de acesso a diretório (LDAP - Lightweight Directory Access Protocol), freqüentemente considerado como padrão capaz de prover acesso a diretório universal, bem como integrar diretórios separados em serviços de diretório de larga escala (Data Connection 1999). É um meio padrão de aplicações clientes e servidores Web da Internet acessarem serviços de diretório on-line sobre redes TCP/IP. Foi concebido originalmente para simplificar o acesso ao serviço de diretório modelado de acordo com X.500. Seu objetivo principal é minimizar a complexidade do cliente facilitando a expansão de aplicações capazes de utilizar o serviço de diretório. O LDAP não é suficiente para definir um padrão de diretório completo, precisando do X.500 para definir todos os aspectos requerido para o fornecimento de um verdadeiro serviço de diretório distribuído. O LDAP deve funcionar tornando a tecnologia de diretório mais disponivel na Internet, intranet e extranet. 
Um serviço de diretório distribuído é definido por um conjunto de protocolos e um modelo de diretório. O LDAP foi projetado como um protocolo de acesso de diretório apropriado para o acesso de usuários. Isolado não é base para uma rede distribuída avançada de servidores de diretório, que precisa ser definida por protocolos e modelo de diretório adicionais. X.500 fornece a definição de um diretório distribuído com protocolos servidor a servidor e modelo de diretório aprovado, e é totalmente complementar, e compatível, ao padrão LDAP.

Ao utilizar LDAP como um protocolo de acesso deve-se definir os protocolos de diretórios distribuídos conforme estabelecido pelo protocolo X.500 ou por outro serviço de diretório cujos dados e serviços sejam suportados pela interface do LDAP. Dessa forma, os serviços de diretório serão baseado no LDAP, que especifica como os usuários acessarão o diretório, mas os serviços precisam ser implementados no padrão X.500 ou outro escolhido.

Se os dados da empresa forem replicados, seja por um protocolo de replicação ou por um cach de dados, é essencial que a administração dos dados seja comum aos servidores (ex. se um servidor tem um mecanismo específico de controlar quais usuários podem acessar dados, somente faria sentido replicar esse dado em servidores que tenham o mesmo mecanismo de controle de acesso).

Os protocolos usados para acessar uma infra-estrutura de diretório LDAP/X.500 são (Mensaging Direct 1999): .

- LDAP -> boa opção para os seguintes tipos de aplicações de diretório acessando do diretório da empresa:

- Ferramentas de acesso a diretório de propósito geral para usuários finais e integração de sistemas;

- Integração com aplicações que requeiram acesso a diretório. Particularmente apropriado para isso pela simplicidade do protocolo e da API.

- CLDAP > boa opção para: 
- Processo de sistema que requeira acesso de leitura a baixos volumes de dados. CLDAP oferece alta performance para essas aplicações, pois não requer estabelecimento de conexão (ex. TCP). É boa opção para aplicações como servidores de mensagem.

- X.500 DAP -> boa opção para:

- Ferramentas de acesso de diretório de propósito geral para usuários finais e integração de sistemas;

- Aplicações integradas a aplicações OSI ou ao ambiente OSI;

- Aplicações que necessitem operações assinadas (única característica significante do DAP não suportado pelo LDAP). Operações assinadas são importantes onde autenticação forte é necessária. Pode ser útil para uma organização usando um firewall DSA para fornecer conectividade de diretório, ou para verificar o cliente ao servidor (ex. controle de acesso) ou verificar o servidor ao cliente.

\subsection{Gerenciamento de Objetos}

Tecnologias de comunicação estão crescendo e precisando de dispositivos acoplados que possam se comunicar com componentes rodando em plataformas de computadores remotos. Tais dispositivos possuem ampla aplicabilidade, como browsers web, e-mail, clientes que precisem entrar em contato com as companhias, etc.

\subsubsection{ActiveX}

A tecnologia ActiveX tem seu principio nos tempos iniciais do Windows (Mshug 1998). A capacidade do Windows de rodar múltiplas aplicações desktop simultaneamente despertou na Microsoft o interesse em permitir que tais aplicações compartilhassem informação em tempo real, o que, a principio, foi permitido através do uso do DDE (Dynamic Data Exchange). Na versão seguinte a Microsoft pretendia permitir não somente o compartilhamento de dados entre aplicações em tempo real, mas também que uma aplicação pudesse existir dentro de outra (ex existência de uma planilha do Excel dentro de um documento do Word). Tal função foi 
denominada OLE, e define o relacionamento entre "aplicações recipientes" e "aplicações servidoras". Por ter sido projetada para ser genérica, softwares de outros vendedores podem funcionar como recipientes ou servidores OLE.

Quando a Microsoft converteu a OLE para a versão do Windows de 32 bits, os desenvolvedores notaram que a tecnologia não era restrita a criação de documentos compostos. Havia-se criado um modo padrão de interação entre duas aplicações sem que tivessem, necessariamente, sido desenvolvidas juntas. O termo OLE havia se expandido para englobar um grande alcance na tecnologia de criação de componentes de software.

Com a importância que a Internet e a WWW adquiriram no campo da computação, OLE encontrou novos desafios. Sua nova versão precisava ser pequena e eficiente para que pudesse ser aplicado sobre links de comunicação lentos, ser capaz de trabalhar igualmente bem em aplicações web, aplicações desktop e aplicações de servidores. O nome OLE entretanto, mudou tanto que um novo termo era necessário para descrever a nova arquitetura. Assim surgiu o nome ActiveX para estabelecer a estratégia Microsoft para componentes de software.

\subsubsection{DCOM}

O modelo de objetos de componentes distribuídos (DCOM - Distributed Component Object Model), antigamente conhecido como OLE de rede, é um protocolo que permite a componentes de software se comunicarem diretamente sobre uma rede de forma confiável, segura e eficiente (Microsoft 1998a). Foi projetado para ser usado através de transportes de rede múltiplos, incluindo protocolos Internet como HTTP. É baseado na especificação da Fundação de Software Aberto DCE-RPC e trabalha com componentes applets Java e ActiveX pelo uso do Modelo de Objetos de Componentes (COM - Component Object Model).

O protocolo DCOM é um protocolo em nivel de aplicação para chamadas de procedimento remoto orientadas a objeto úteis para todo tipo de sistemas distribuidos (Horstmann et. al. 1997). É um protocolo genérico que facilita a construção de protocolos de comunicação especificos 
através de características como a habilidade de realizar conexões autenticadas e escolher níveis de segurança de canal.

O DCOM estende o COM a suportar comunicação entre objetos em diferentes computadores em uma LAN, uma WAN ou mesmo na Internet. Com o DCOM a aplicação pode ser distribuída em locais que melhor se adaptem à empresa e à própria aplicação. O DCOM é tido como o TCP/IP dos objetos (Microsoft 1996). Define como componentes e seus clientes interagem, de forma que o cliente e o componente possam se conectar sem a necessidade de qualquer componente de sistema intermediário. Nos sistemas operacionais atuais, um cliente que precise se comunicar com um componente em outro processo não pode chamar o componente diretamente, precisando usar alguma forma de comunicação interprocessos provida pelo sistema operacional. COM provê essa comunicação de forma completamente transparente: ele intercepta chamadas do cliente e as passa ao componente no outro processo. A figura 3.2 mostra como as bibliotecas COM/DCOM em tempo de execução fornecem a ligação entre o cliente e o componente. Se o cliente e o componente estiverem em máquinas diferentes, DCOM substitui a comunicação interprocessos local por um protocolo de rede, sem que o cliente e o componente percebam a diferença. A figura 3.3 mostra essa arquitetura, onde o COM provê a cliente e componente, em tempo de execução, serviços orientados a objetos usando RPC e o provedor de segurança para gerar pacotes de rede padrão conforme o padrão do protocolo DCOM.

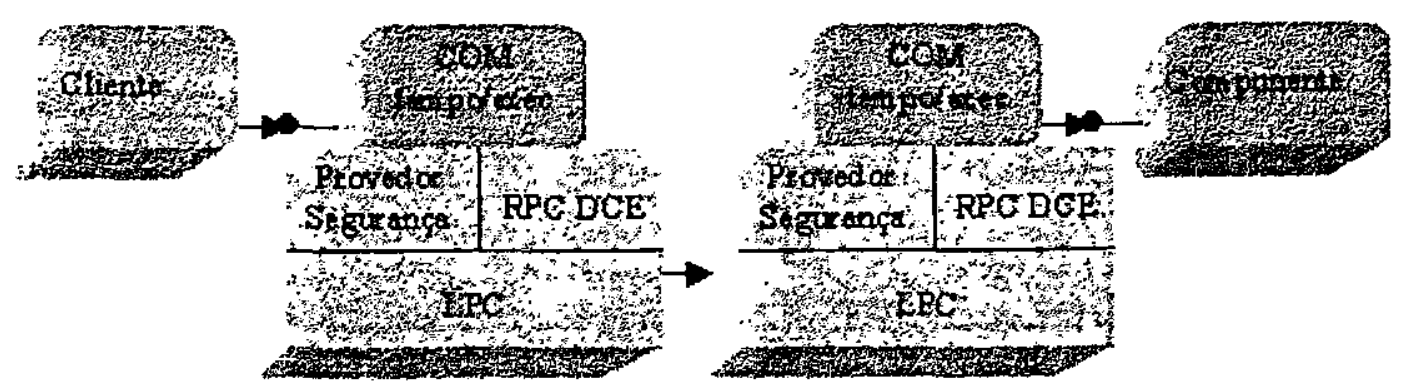

Figura 3.2. Componentes COM em processos diferentes (Microsoft 1996). 


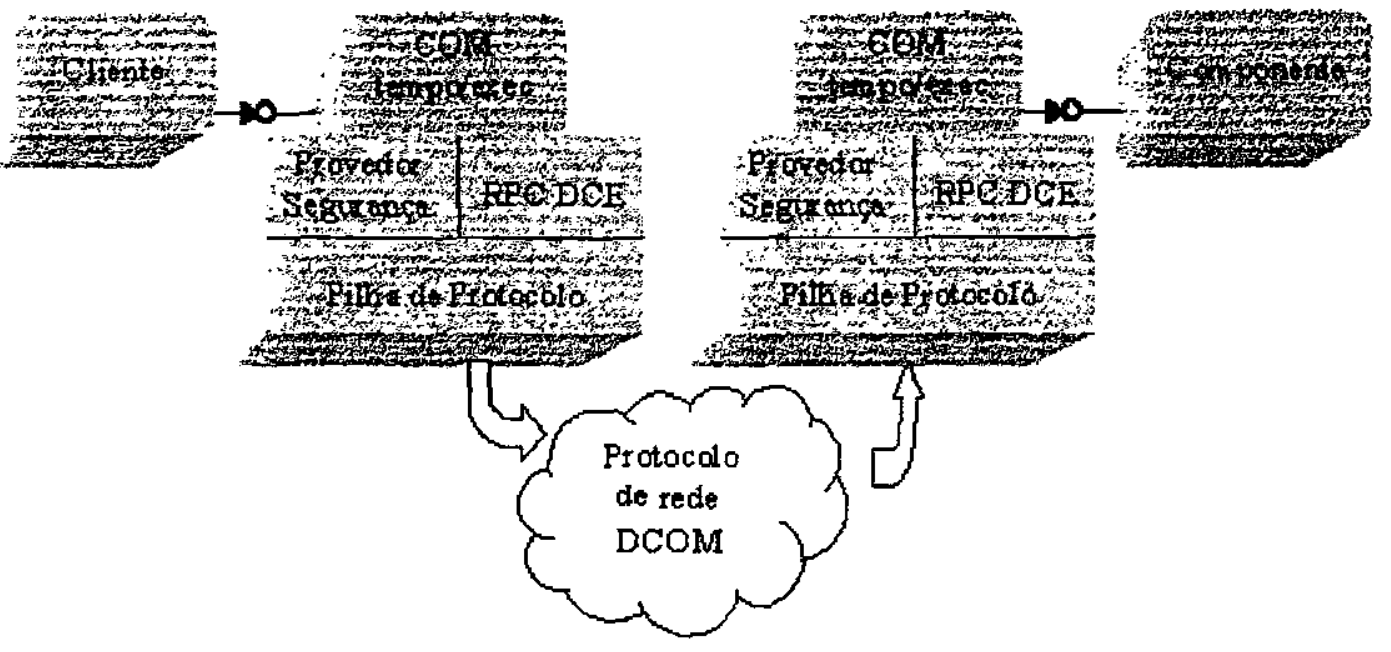

Figura 3.3. Componentes COM em máquinas diferentes (Microsoft 1996).

DCOM está no centro dos componentes da aplicação provendo sua união (figura 3.4), e provê uma extensão com um framework de segurança personalizado útil nos projetos de aplicações, distinguindo entre quatro aspectos fundamentais de segurança:

- Segurança de Acesso: quem tem permissão para chamar um objeto?

- Segurança de Lançamento: quem tem permissão para criar um objeto novo em um processo novo?

- Identidade: o que é a segurança do objeto em si?

- Policiamento de Conexão: integridade - mensagem podem ser alteradas?, privacidade mensagens podem ser interceptadas por outros?, autenticação - objeto pode descobrir ou assumir a identidade daquele que o chamou? 


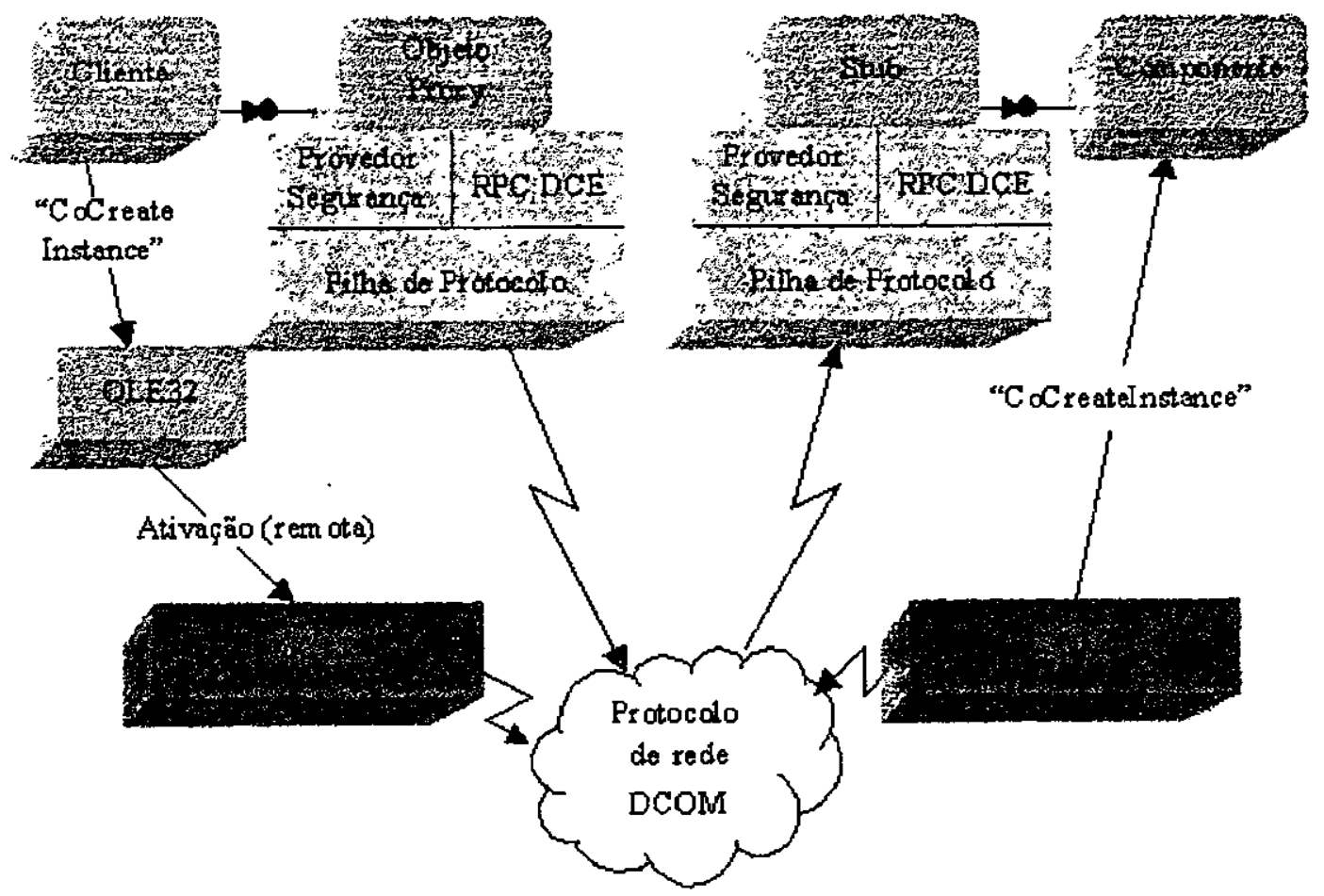

Figura 3.4. DCOM no centro dos componentes da aplicação (Microsoft 1998b)

Em suma, DCOM oferece facilidades para projetar aplicą̧ões distribuidas que:

- Altere a escala de um único computador pequeno para um grande conjunto de máquinas servidoras;

- Forneça comunicação rica e simétrica entre componentes;

- Possa ser expandido fortemente para encontrar novos requerimentos funcionais;

- Tire vantagem de comportamentos existentes;

- Integre times de peritos em qualquer linguagem de programação ou ferramenta de desenvolvimento;

- Use a bandwidth com cautela, enquanto provendo grande tempo de resposta para usuários finais;

- Seja inerentemente segura;

- Forneça caminho de migração suave a característica sofisticadas de balanceamento de carga e tolerância a falhas;

- Possa ser aplicada e administrada eficientemente;

- Possa ser usada com qualquer protocolo de rede e integrada a qualquer plataforma de hardware; 
- Possa tirar vantagem de outros protocolos e padrões da Internet.

\subsection{3. $C O R B A$}

CORBA (Common Object Request Broker Architecture), criado pela OMG (Object Management Group), é uma integração tecnológica e não uma tecnologia de programação. Foi especificamente projetado para unir tecnologias de programação (Curtis 1997). Não existe como um ponto no espaço de programação; pelo projeto, ocupa o espaço entre linguagens individuais (figura 3.5). Quando um cliente Java usa tecnologia CORBA para se comunicar com um objeto $\mathrm{C}++$, por exemplo, ambos os programadores, $\mathrm{C}++$ e Java, trabalham completamente dentro de seus respectivos ambientes de linguagem. O ORB (Object Request Broker) CORBA apresenta o cliente Java com uma interface stub Java e o programador C++ com uma interface skeleton (figura 3.6). CORBA cuida da discussão entre as linguagens automaticamente. Essa figura reflete o fato de que CORBA é especificamente projetada como uma tecnologia de integração, e não uma tecnologia de programação.

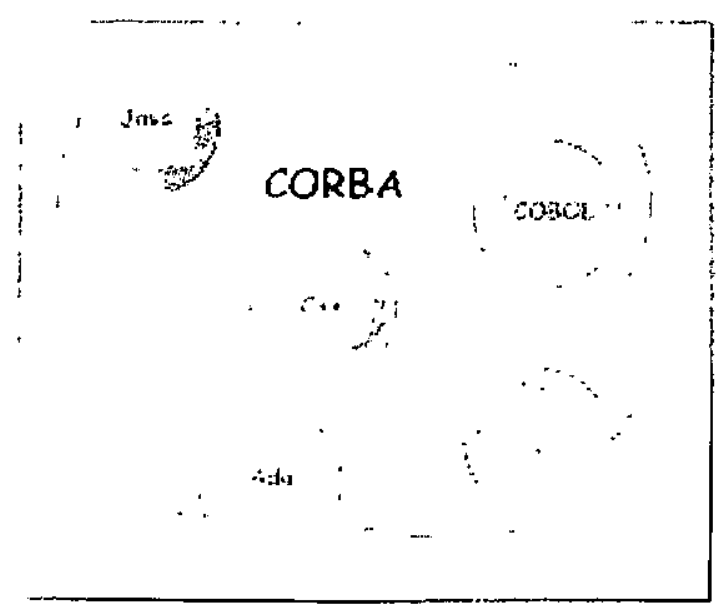

Figura 3.5. (Object 1997) 


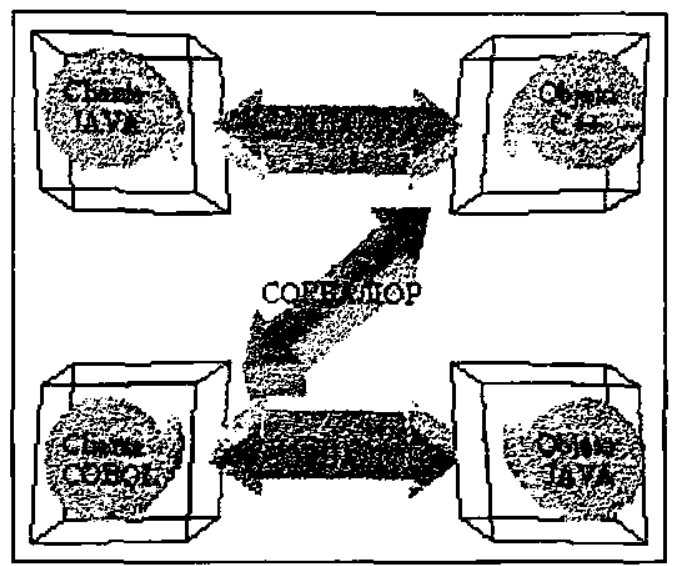

Figura 3.6. (Object 1997)

CORBA realiza essa integração através da IDL (Interface Definition Language), que não é uma linguagem de programação. A IDL descreve interfaces entre componentes distribuídos, e não depende de nenhuma tecnologia de linguagem de programação em particular. Para as descrições de interface da $\mathrm{DL}$, um produto ORB gera automaticamente códigos na linguagem escolhida para efetuar a integração e distribuição. Ela conecta componentes e gerencia a comunicação entre eles.

O CORBA pode ser definido como um padrão para objetos distribuídos, que permite a uma aplicação requisitar um procedimento a ser realizado por um objeto distribuído e cujos resultados lhe serão retornados (Arellano 1998). Essa é uma ação do tipo cliente/servidor. Um dado pode ser transmitido do cliente para o servidor e é conectado a um método particular em um objeto particular. Após o processo o dado é retornado ao cliente.

O padrão CORBA cria um ambiente que permite a distribuição de aplicativos, tornando possível para os desenvolvedores produzirem aplicações que se comuniquem e utilizem recursos remotos como se fossem locais. Aplicações podem concluir procedimentos de diferentes objetos, sem se importar em onde o objeto se encontra no momento. Essa habilidade é conhecida por "ilusão de localidade" CORBA. O desenvolvedor não precisa se preocupar com protocolos, programação de sistemas de baixo nível, e passagem de mensagens, podendo se concentrar apenas no desenvolvimento da aplicação, e não na infra-estrutura necessária ao sucesso do sistema distribuido. 


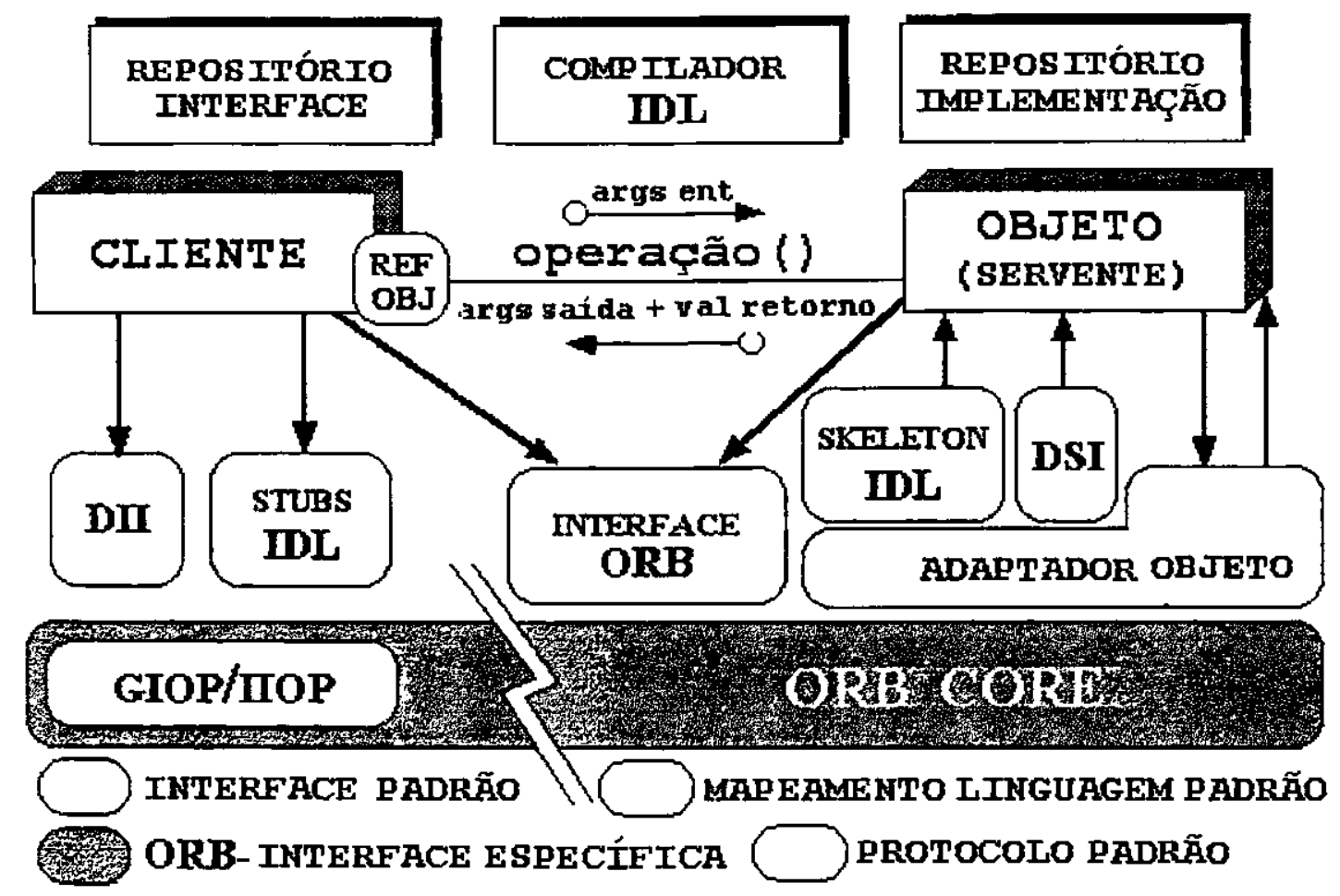

Figura 3.7. Arquitetura ORB do CORBA (Schimidt 1999)

A figura 3.7 mostra a arquitetura ORB do CORBA (Schmidt 1999). O ORB é o middleware que gera o relacionamento cliente/servidor entre os objetos, permitindo a um cliente chamar, transparentemente, um objeto sem se importar com sua localização. Isso faz com que o requerimento do cliente pareça uma chamada de procedimento local. O ORB pega a chamada, encontra o objeto apropriado, faz o requerimento em favor do objeto passando todos os parâmetros necessários, e retorna o resultado(Schmidt 1999; OMG 1995). CORBA provê a garantia de que uma requisição, ou outro tipo de mensagem, é recebida pelo objeto apropriado, a despeito de demoras ou falhas (Garon et. al. 1997).

Eis algumas vantagens do CORBA (Mowbray 1998):

- Suporta todas as plataformas e linguagens existentes, e suporta unir essas linguagens dentro de uma aplicação distribuída;

- Suporta distribuição e orientação a objetos;

- É um padrão da indústria, o que cria competição entre vendedores e garante a existência de qualidade. Seu uso também fornece, ao desenvolvedor, um certo grau de portabilidade entre implementações; 
- Provê um alto grau de interoperabilidade, o que garante a comunicação entre objetos distribuídos construídos no tipo de produtos CORBA diferentes;

- Grande companhias não precisam enviar um único produto CORBA para todo o desenvolvimento;

- Existem muitas empresas envolvidas com o CORBA, incluindo companhias de hardware, software, cabo, telefone, bancos, etc.

\subsection{Tecnologias de Empacotamento}

Para a realização da transferência da informação torna-se necessária a união dos dados, de forma que possam ser enviados pela rede. Essa união é feita agrupando-se os dados em pacotes nos formatos especificados pelos protocolos de transporte. As Tecnologias de Empacotamento são utilizadas para formatar as informações nesses pacotes.

\subsubsection{MIME}

O MIME (Multipurpose Internet Mail Extensions - RFC 1521) é um formato para Internet padrão desenvolvido pela IETF, que oferece um meio de representar e codificar uma grande variedade de tipos de dados, incluindo texto fora do padrão ASCII, para transmissão por mail na Internet. Ele estende RFC 822 de maneira simples, flexível e aberta a extensão (Borenstein 1992; Beck 1997).

O serviço de e-mail é bastante utilizado em muitas redes, inclusive a Internet. $\mathrm{O}$ padrão da Internet para formato de mensagens, o RFC 822, limita os dados a serem transmitidos a textos do padrão ASCII, não permitindo aos usuários o envio de figuras, áudios, textos em muitas línguas diferentes do inglês, etc. Pesquisas e sistemas comerciais, incluindo Borenstein et. al. 1991 e Forsdick et. al. 1984, falam da factibilidade de um mail mais rico. O que faltou, entretanto, foram padrões de formato que permitissem sistemas interoperarem, pois cada sistema permitia que seus usuários enviassem mails multimídia em um formato compreensivel apenas a outros usuários que utilizassem o mesmo software. 
O formato MIME enumera sete tipos válidos:

1. Texto - é o tipo default, com subtipos associados com formatos de textos mais ricos;

2. Imagem - subtipos são nomes de formatos de imagens, dois dos quais, "imagem/gif" e "imagem/jpeg", são definidos pelos leitores de mail do MIME que não reconhecem formatos de imagem, mas ainda assim saberão que se trata de uma imagem, percebendo que não é útil apresentar as linhas de dados do arquivo;

3. Áudio - subtipos são nomes de formatos de áudio. O subtipo "audio/basic" denota dado de áudio de canal simples de $8000 \mathrm{~Hz}$ u-law;

4. Vídeo - Analogamente, os subtipos correspondem a nomes de formatos de vídeo, tal como o tipo definido no MIME "video/mpeg";

5. Mensagem - esse tipo é usado para encapsular uma mensagem completa no padrão RFC 822 (ex. pode ser usado para reenviar ou rejeitar um mail). O padrão define dois subtipos de mensagem: "mensagem/parcial" pode ser usada para quebrar uma mensagem grande em várias partes para transporte, de maneira que possam ser colocadas de volta automaticamente no outro lado, e "mensagem/corpo-externo" que pode ser usado para passar um corpo grande de mensagem por referência, ao invés de incluí-la por inteiro;

6. Multiparte - esse tipo é usado para empacotar várias partes, de tipos e subtipos possivelmente diferentes, em um único corpo de mensagem do tipo RFC 822;

7. Aplicação - para ser usado com outros tipos de dados que não se encaixem em nenhuma dessas categorias.

\subsection{2. $M P E G$}

O Grupo de Especialistas em Imagem em Movimento (MPEG - Moving Picture Experts Group) é um comitê unido da Organização de Padronização Internacional (ISO - International Standardization Organization) e da Comissão Eletrotécnica Internacional (IEC - International Electrotechnical Commission). Esse grupo se reúne em uma média de quatro vezes por ano para gerar padrões para vídeo digital e compressão de áudio.

Em janeiro de 1992, o comitê completou o esquema do MPEG-1, que define uma cadeia de bits (bit stream) de vídeo e áudio comprimido para ser transferido em uma taxa de 1.5 megabits por 
segundo. Entretanto é possível gerar arquivos MPEG-1 à velocidade de 4-5 Mbits/segundo (Tribeca 1997). A importância da taxa mais baixa é devido a ser a mesma de CD-ROM's, Video$C D$ 's e CD-i's. Há três partes no esquema, que são: vídeo, áudio e sistemas. O último integra cadeias de vídeo e áudio com o "selo de tempo" apropriado para permitir sincronização.

A aprovação final do MPEG-2 também possui três partes: sistemas, video e áudio, como o padrão internacional foi passado pelo vigésimo nono encontro do MPEG em Singapura, em novembro de 1994. Esse esquema define uma cadeia de bits de compressão de vídeo e áudio para taxas de 2 a10 Mbits/segundo. A aplicação original para o MPEG-2 foi uma transmissão broadcast totalmente digital de vídeo com qualidade de TV, porém não incluindo HDTV.

O MPEG-3 teve seu projeto inciado com a intensão de abranger HDTV. Foi cancelado, entretanto foi cancelado ao perceberem que tal caracteristica poderia ser implementada como uma extensão do MPEG-2, ao qual foi incorporada (ISO 1997).

O MPEG-4 teve o início de sua fase de padronização em setembro de 1993, e visa atender três áreas: televisão digital, aplicações gráficas interativas e WWW, além de fornecer padrões para integrar a produção, distribuição e acesso ao conteúdo da informação audiovisual.

MPEG-5 e MPEG-6 não foram definidos. O MPEG-7 tem como nome formal "Interface de Descrição do Conteúdo Multimídia" (ISO 1997a), especificará um conjunto padrão de descritores e esquemas de descrição usados para especificar o conteúdo da informação, com a finalidade de tornar a busca da informação multimídia mais rápida e eficiente.

\subsection{3. $E D I$}

EDI (Eletronic Data Interchange) é a troca de documentos de negócios, de forma eletrônica padronizada, entre duas aplicações de negócios automaticamente. Não há restrição no formato do dado ou do método de comunicação usado (Orion 1999).

Informação pode ser enviada como um mail - efetivamente um memorando eletrônico. Entretanto, não é trivial escrever um programa computacional que entenda um mail e se 
comporte de acordo com o conteúdo automaticamente. É nesse ponto que entra o EDI. Definindo-se um padrão para a troca de informação eletrônica, pode-se criar, efetivamente, um meio eletrônico de enviar um modelo, que pode ser gerado automaticamente por um parceiro comercial e automaticamente processado por outro.

Tecnicamente, o importante é que os parceiros entendam os dados que seus parceiros enviam. Entretanto, se há parceria com mais de um parceiro, faz mais sentido, e se torna mais barato, se todos usarem o mesmo formato de dados. Essa é a razão pela qual os padrões EDI nacionais e internacionais foram desenvolvidos. Os principais padrões EDI conhecidos são (Orion 1999):

- EDIFACT - padrão internacional aprovado pelas Nações Unidas;

- ANSI X12 - padrão principal dos Estados Unidos;

- Tradacoms - padrão do Reino Unido;

- ODETTE - padrão automotivo europeu - migrando definitivamente para o EDIFACT;

- VDA - padrão automotivo alemão.

\subsection{Gerenciamento de Redes}

Para que as funcionalidades sobre redes citadas possam funcionar de forma adequada, é necessário que a rede seja bem mantida e gerenciada, evitando com isso, o surgimento de falhas e imprevistos que prejudiquem o sucesso dos serviços funcionando sobre ela.

\subsubsection{SNMP}

O SNMP (Simple Network Management Protocol) foi desenvolvido no final da década de 80 para prover um protocolo de gerenciamento de redes de propósito geral. Seu objetivo primário era ser simples a ponto de nada interferir em sua aplicação. Para isso, ele tem sido bastante eficiente como é atualmente usado em muitos produtos de rede no mercado (Intermec 1999).

O SNMP foi criado com pensando-se em tempo para o mercado: robustez em frente a falhas da rede, baixo overhead nos dispositivos rodando o protocolo, e facilidade em resolver problemas 
do protocolo em si. Assim, ele se limitou ao uso do UDP (User Datagram Protocol), o que deu a quem implementa a habilidade e a responsabilidade de gerenciar pacotes perdidos e realizar qualquer retransmissão necessária. Uma vez que o protocolo de gerenciamento de rede rode continuamente, é essencial que consuma o mínimo possível em recursos da rede. UDP permite o controle necessário sobre transmissões de pacotes, tamanho de pacotes e conteúdo.

O SNMP tem três primitivas de controle que iniciam o fluxo de dados a partir do requisitante. Tem duas primitivas de controle que o receptor usa para responder. Uma é usada em resposta à questão direta do requisitante e a outra é uma resposta assíncrona para obter a atenção do requisitante. Todas as cinco primitivas são transmitidas por UDP e são limitadas em tamanho pela quantidade de dados que pode ser enviada em um único pacote UDP.

\subsection{Tecnologia de Agentes Móveis}

$\mathrm{O}$ uso de agentes móveis vem adicionar algumas características às funções tradicionais das ferramentas de busca. Os agentes móveis são programas computacionais (softwares) e têm a capacidade de se transportarem de uma máquina para outra, o que os torna capazes de realizar uma busca pela informação na Internet.

\subsubsection{Agentes}

Um agente pode ser definido como uma entidade que age de forma autônoma em nome do usuário e com sua autorização. Ao dizermos "Agentes" neste trabalho queremos nos referir a "Agentes de Software", que são softwares desenvolvidos para representar um usuário, ou um sistema, no âmbito computacional.

"A idéia de um agente originou-se com John McCarthy em meados dos anos 50, e o termo foi concebido por Oliver G. Selfridge alguns anos depois, quando estavam ambos no MIT (Massachussetts Institute of Technology). Eles tinham uma visão de um sistema que, quando dado um objetivo, pudesse descobrir os detalhes das operações computacionais apropriadas e pudesse pedir e receber avisos, oferecidos em termos humanos, quando estivesse encalhado. Um 
agente seria um 'soft robot' vivendo e fazendo seus negócios dentro do mundo computacional" (kay 1984).

Há diferentes definições sobre agentes. Tentando apresentar uma definição bastante abrangente Franklin e Graesser (Franklin \& Graesser, 1996) definem, após comparação entre diversas definições de agente em vários sistemas, o conceito de agente autônomo: "Um agente autônomo é um sistema situado em um ambiente, e parte do mesmo, que percebe aquele ambiente e age sobre o mesmo no decorrer no tempo, de acordo com sua própria agenda e de modo a afetar $o$ que ele perceberá no futuro".

Franklin e Graesser apresentam a classificação dos agentes segundo a tabela 3.1.

\begin{tabular}{|l|l|l|}
\multicolumn{1}{|c|}{ Propriedade } & \multicolumn{1}{c|}{\begin{tabular}{c}
\multicolumn{1}{c|}{ Outros } \\
Nomes
\end{tabular}} & Signilicado \\
\hline Reativo & (percepção e ação) & $\begin{array}{l}\text { Responde de forma a mudanças no } \\
\text { ambiente }\end{array}$ \\
\hline Autônomo & $\begin{array}{l}\text { Exerce controle sobre suas próprias } \\
\text { ações }\end{array}$ \\
\hline Orientado a metas & $\begin{array}{l}\text { Com propósito pró- } \\
\text { ativo }\end{array}$ & $\begin{array}{l}\text { Não age simplesmente em função do } \\
\text { ambiente }\end{array}$ \\
\hline Temporalmente contínuo & & $\begin{array}{l}\text { E um processo executando } \\
\text { continuamente }\end{array}$ \\
\hline Comunicativo & Socialmente capaz & $\begin{array}{l}\text { Comunica-se com outros agentes, } \\
\text { possivelmente com humanos }\end{array}$ \\
\hline Inteligente & Adaptável & $\begin{array}{l}\text { Muda seu comportamento com base } \\
\text { na sua experiência anterior }\end{array}$ \\
\hline Móvel & & $\begin{array}{l}\text { Capaz de se mover de uma máquina } \\
\text { para outra }\end{array}$ \\
\hline Flexível & & $\begin{array}{l}\text { Ações não são definidas através de } \\
\text { scripts }\end{array}$ \\
\hline Caráter & $\begin{array}{l}\text { Personalidade e estado emocional } \\
\text { críveis }\end{array}$ \\
\hline
\end{tabular}

Tabela 3.1. Possíveis propriedades de agentes (Franklin e Graesser,1996)

Segundo (Rodrigues 1999) os agentes são divididos em dois tipos: os Agentes Estáticos e os Agentes Móveis. 
Agentes Estáticos são executados somente no sistema onde têm sua execução iniciada, necessitando se valer de mecanismos de comunicação, como RPC, para interagir com qualquer componente de outro sistema.

Agentes Móveis podem se transportar entre diferentes sistemas, dispensando assim o uso de mecanismos de comunicação para interagir com componentes de outros sistemas que não aquele no qual começou a ser executado. Quando um agente móvel deseja interagir com algum objeto que está fora de seu sistema, ele possui a habilidade de se transportar para o sistema em que se encontra esse objeto, onde então a interação é realizada.

Nwana (1996) considera essa divisão entre agentes estáticos e agentes móveis como apenas uma das dimensões possiveis de divisão. Considerando essa como a primeira dimensão, segundo o trabalho de Nwana (1996) restam ainda divisões nas seguintes dimensões:

- modo de funcionamento deliberativo ou reativo do agente. Um agente deliberativo possui um modelo de raciocínio simbólico interno, que permite que ele planeje e negocie tarefas com outros agentes de modo a coordenar a execução. Agentes reativos, por outro lado, apresentam um comportamento do tipo estímulo/resposta, ou seja, o agente responde ao estado atual do ambiente no qual ele está imerso.

- classificação de acordo com propriedades ideais e fundamentais que um agente deveria apresentar. Nwana cita três propriedades: autonomia, aprendizagem e cooperação.

- o papel assumido pelo agente na aplicação, por exemplo, agentes de informação para WWW.

- categoria dos agentes híbridos, que combinam duas ou mais das outras dimensões citadas em um único agente.

$\mathrm{Na}$ vida real as pesquisas e aplicações apresentam agentes em várias dessas dimensões. Nwana cria, baseando-se em tais dimensões, sete tipos de agentes que cobrem a maioria dos tipos em investigação atualmente.

- Agentes colaboradores - envolve autonomia e cooperação com outros agentes para a realização de suas tarefas.

- Agentes de interface - envolve autonomia e aprendizagem. Uma boa materialização desse tipo é o assistente pessoal que auxilia o usuário. A intenção é atribuir tarefas aos agentes 
facilitando o trabalho de usuários novatos que ainda não têm conhecimento ou experiência suficiente para a execução do trabalho.

- Agentes móveis - são capazes de se locomoverem através das redes de computadores. Durante sua "viagem" através das redes podem interagir com processos nas diferentes máquinas que passam com o intuito de coletar informações que o auxiliem a concluir seu trabalho, quando então retornam à sua origem.

- Agentes de informação (para Internet) - trabalha com informações de diferentes fontes gerenciando-as, manipulando-as e ordenando-as. Esse tipo de agente é bastante útil com pesquisa de grandes quantidades de informação. $O$ usuário pode estipular um tópico de seu interesse e o agente se encarrega de providenciar-lhe de forma organizada uma lista de opções, podendo para isso utilizar outras tecnologias, como mecanismos de busca on-line pela WWW.

- Agentes reativos - agem através de estímulos e respostas de acordo com o estado atual do ambiente em que estão imersos. São compostos por módulos autônomos com tarefas bem específicas.

- Agentes híbridos - agentes concebidos através da integração de mais de uma filosofia existente.

- Agentes inteligentes - apresentam autonomia, aprendizagem e cooperação. Realizam suas ações atuais de acordo com o estado em que se encontram e com o que "aprenderam" em experiências passadas.

Nwana caracteriza como sistemas de agentes heterogêneos aqueles que se utilizam de mais de um desses tipos de agentes.

O interesse maior em nosso trabalho é sobre os agentes móveis, e mais adiante explicitaremos o porquê.

\subsubsection{Agentes Móveis}

No processo que os agentes móveis realizam de se transportarem entre diferentes sistemas eles carregam consigo seu estado e seu código. Seu estado pode ser determinado como o estado atual 
de execução ou como valores de atributos que indiquem um ponto de início do agente no sistema destino.

A mobilidade não é uma característica necessária ao conceito de agente, porém os agentes móveis apresentam algumas vantagens sobre os agentes estáticos, no que se refere, por exemplo, a: custos de comunicação mais reduzidos, independência da limitação imposta pelo uso de recursos locais, coordenação mais fácil, computação assincrona, ambiente de desenvolvimento natural para serviços de comércio, arquitetura flexível para computação distribuida, etc.

Existem vários trabalhos realizados para avaliar a factibilidade e as vantagens do uso de agentes móveis. Um dos trabalhos mais citados em toda a literatura é o relatório de pesquisa de Harrison, Chess e Kershenbaum (1997), posteriormente publicado também como artigo, que apresenta possíveis vantagens e desvantagens comparando o uso de agentes móveis com o uso de técnicas tradicionais de implementação de sistemas distribuídos (ex. RPC).

No trabalho de Fuggeta, Picco e Vigna (1998) diferentes aplicações são citadas como aplicações a tirarem proveito do uso de agentes móveis, como busca de informação distribuida, serviços de telecomunicação avançados, configuração e controle de dispositivos remotos, gerenciamento de fluxo de trabalho (workflow) e comércio eletrônico, entre outros. Reami (1998) descreve um sistema de defesa à intrusões em sistemas computacionais baseado em agentes.

Citaremos agora alguns conceitos dos agentes móveis (Rodrigues 1999).

- O agente possui uma autoridade que identifica o usuário ou a organização em nome da qual ele está atuando e um nome dado pela autoridade através do qual é identificado e pode ser localizado e gerenciado.

- A localização de um agente é o endereço de um "place" (lugar) dentro de um sistema de agentes, que é uma plataforma que pode criar, executar, interpretar, transferir e terminar um agente. $O$ endereço da localização de um agente possui o nome do sistema de agentes e o nome do lugar em que o agente se encontra.

- Existe uma Infra-estrutura de Comunicação (CI) através da qual são feitas as comunicações entre os sistemas de agentes. A CI fornece também o serviço de nomes e de 
segurança, e o place em que se encontra o agente pode fornecer funções tal como o controle de acesso.

\subsubsection{Segurança de Agentes}

$\mathrm{O}$ uso de agentes móveis deve estar sempre acompanhado com preocupaçōes a respeito de possibilidades de ataques, o que nos leva a considerar e procurar por segurança sobre essa tecnologia.

Dois tipos de ataques podem ocorrer com o uso de agentes móveis:

- Ataque ao host

- Ataque ao agente

Um vírus pode ser caracterizado como um agente móvel, uma vez que ambos apresentam características comuns, como as quatro primeiras características da tabela 1 . O problema de ataque ao host se dá nesse contexto quando o agente móvel é desenvolvido para realizar ataques, bem como um vírus. O agente pode atacar e afetar o host que o está "hospedando", realizando tarefas como obter informações sigilosas, alterar dados internos, etc.

Por outro lado, o ataque ao agente acontece quando um host mal intencionado resolve atacar um ou mais agentes que cheguem até ele. $\mathrm{O}$ host pode tentar alterar dados armazenados pelo agente, como rotas e escolhas. Supondo que a função do agente seja procurar melhores preços para um determinado produto, o host pode alterar suas informações de forma que a escolha do agente seja ele próprio, independente de ser a melhor opção visitada pelo agente ou não, e ainda alterar sua rota de forma que a partir de então as visitas sejam somente a hosts de pior opção ou direto de volta ao seu proprietário. Essa é uma forma de sabotar o serviço do agente. Outro tipo de ataque seria o roubo de moeda eletrônica que o agente possa estar levando consigo com o intuito de realizar compras.

A proteção do host contra agentes mal intencionados pode ser realizada através de técnicas como listas de controle de acesso e autenticação. A proteção de agentes contra hosts mal intencionados 
é mais complicada (Chess et al, 1995). A criação de ambientes de agentes que possam garantir segurança vem sendo pesquisada, porém a maior dificuldade é em relação à proteção dos agentes contra ações prejudiciais de hosts mal intencionados (Vitek \& Tschudin 1997; Sander \& Tschudin, 1998b).

Vitek, Serrano e Thanos (1997) classificam alguns problemas de segurança e sugerem soluções, tais como:

- Comunicação segura entre hosts e os ambientes computacionais (ACs) onde os agentes são executados, evitando a revelação de informações sigilosas e a comupção de dados e códigos;

- Autenticação e garantia de direitos de acesso às computações recebidas, identificando assim o autor da operação e atribuindo-lhe as devidas responsabilidades;

- Controle do acesso aos recursos locais do host;

- Proteção do AC contra computações possivelmente maliciosas, garantindo obediência às regras de segurança do sistema;

- Proteção dos sistemas de objetos móveis entre eles, impedindo que um possa interromper a computação ou conseguir informações privilegiadas de outro.

\subsubsection{Agentes Móveis na Busca de Informações}

Como pode ser notado em diferentes pontos colocados nas seções acima, o uso de agentes móveis pode oferecer grandes facilidades no sentido de busca de informações através de redes de computadores.

EV's estão constantemente utilizando a Internet para efetuarem suas comunicações e buscas por novas oportunidades e/ou novos parceiros. Já no início de todo o processo de uma EV, alguém busca por uma oportunidade de negócio em que possa trabalhar. Assim que uma oportunidade é identificada e estudada, aquele que a encontrou, seja um profissional interessado em trabalhar na área, seja um agente que procura montar negócios ou ainda uma pequena empresa, precisa encontrar parceiros que apresentem competências necessárias à realização do trabalho requeridos pela oportunidade. Uma vez encontrados os parceiros a EV pode ser montada e a oportunidade explorada. 
Tanto durante o processo de procura por oportunidades quanto durante o processo de procura por parceiros os agentes móveis podem ser de grande utilidade. (Harrison et. al. 1995) relata que já em 1995 a nova tecnologia de agentes móveis era considerada como uma facilidade para as tarefas de Comércio Eletrônico. Agentes móveis podem ser desenvolvidos e configurados para realizarem pelo usuário grandes buscas através da Internet. (Rodrigues 1999) implementa um agente móvel para recolher informação sobre produtos ou serviços num ambiente de comércio eletrônico suportado pela plataforma CORBA, fornecendo eventualmente facilidades para que $o$ cliente possa fazer uma negociação do produto procurado.

O trabalho de (Rodrigues 1999) requer que o usuário forneça ao agente informação suficiente a respeito dos itens procurados, permitindo uma certa flexibilidade quanto a variações para algumas propriedades. As informações requeridas são: tipo do produto (ex. carro, livro, casa, etc.), propriedades que identifiquem o produto (ex. marca, modelo, cor) e um intervalo para o preço desejado. $O$ agente possui um módulo específico de decisão. Esse módulo, de acordo com sua lógica interna e os dados fornecidos pelo usuário, aciona um outro módulo que se encarrega da realização de consultas em catálogos. Após tais consultas as respostas são analisadas pelo módulo de decisão que gera resultados ou ordena novas consultas.

Tais caracteristicas podem ser adaptadas para o desenvolvimento de um agente móvel que possa ser utilizado na busca de oportunidades e parceiros para possiveis EV's.

Bem como o tipo de um produto e suas propriedades, podem ser passadas a um agente características que especifiquem um tipo de oportunidade desejada (ex. assunto de interesse, tempo estimado para o projeto, remuneração oferecida, etc.) ou as competências almejadas em possíveis parceiros (ex. confecção de determinados tipos de malhas, capacidade de realizar determinada qualidade de costura, equipamento para silk, fornecimento de matéria-prima, etc.). Um agente alimentado com tais informações pode realizar buscas através da Internet e fornecer à $\mathrm{EV}$, ou àquele que pretende formá-la, uma série de opções que podem ser investigadas e organizadas segundo seus próprios critérios. 
Um agente desenvolvido para esse tipo de operação poderia ser visualizado segundo a figura 3.8 (busca por oportunidade de negócio) e figura 3.9 (busca por parceiros com competências necessárias à exploração da oportunidade), com o funcionamento de acordo com os itens enumerados a seguir:

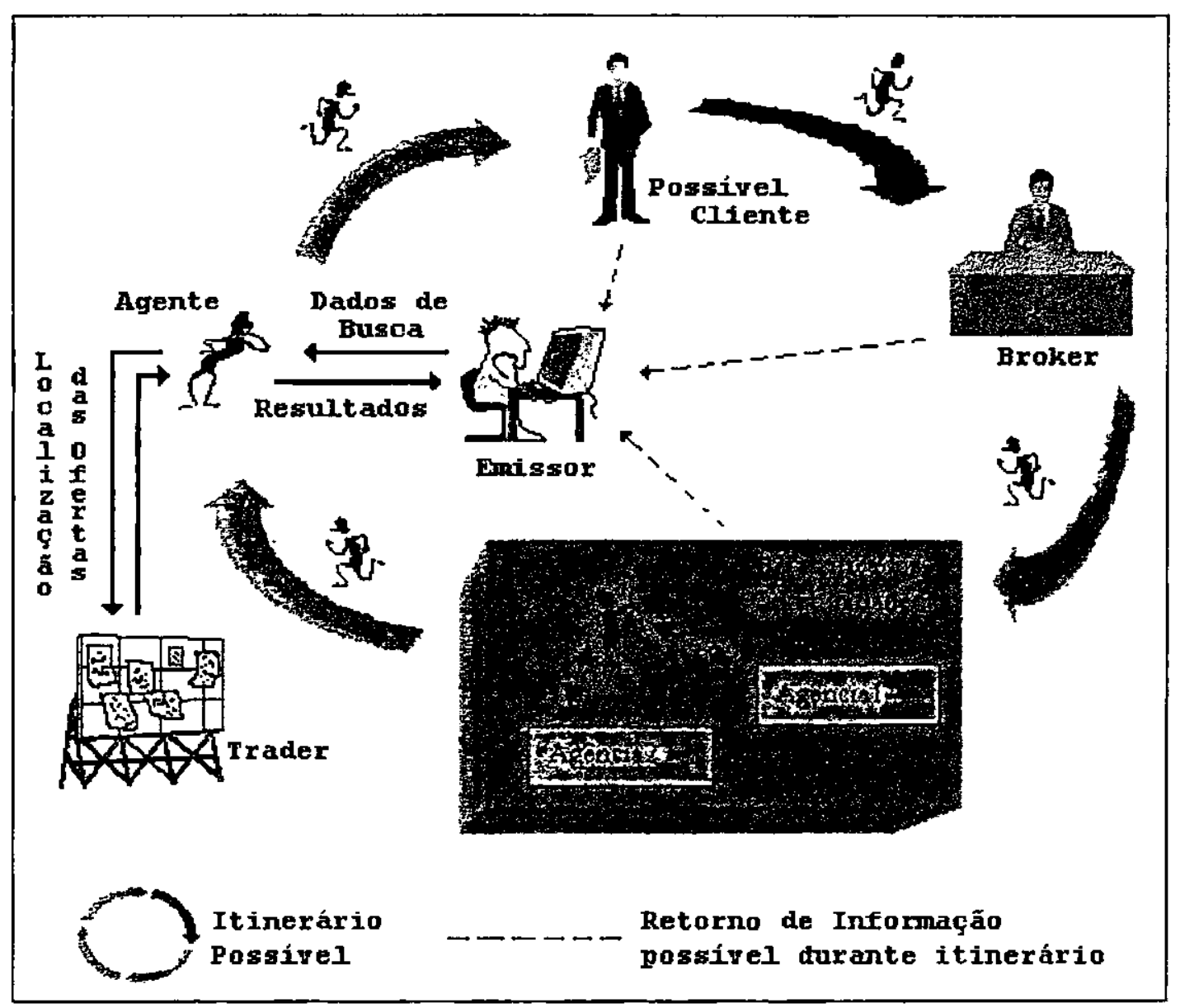

Figura 3.8. Cenário da busca por oportunidades de negócios

1. O agente é invocado pelo pretenso formador de uma EV que passa-lhe o que é desejado (tipo de oportunidade de negócio ou competências procuradas em possíveis parceiros), os requerimentos de busca e, eventualmente, algum itinerário;

2. Durante sua operação, em qualquer ponto do itinerário, o agente pode invocar um objeto Trader (objeto através do qual outros objetos podem anunciar seus serviços) para conseguir a localização de fornecedores da informação procurada (ex. classificados de oportunidades ou sites que apresentem empresas relacionadas e suas competências), o que pode causar mudanças no itinerário previsto; 
3. O agente se move para interagir com possíveis clientes, Brokers (Corretores) ou possíveis parceiros na composição da $\mathrm{EV}$, onde pode se interagir com uma ou mais agências ( possíveis empresas clientes - com oportunidades de negócio - ou parceiras na EV - com competências relevantes ao projeto);

4. Para o caso de um agente se deparar com locais sem suporte para agentes, a comunicação é realizada via rede a partir do ponto mais próximo;

5. As informações podem ser transmitidas ao emissor do agente parcialmente em qualquer ponto do itinerário ou totalmente ao final do percurso quando o agente retorna ao seu ponto de origem. 


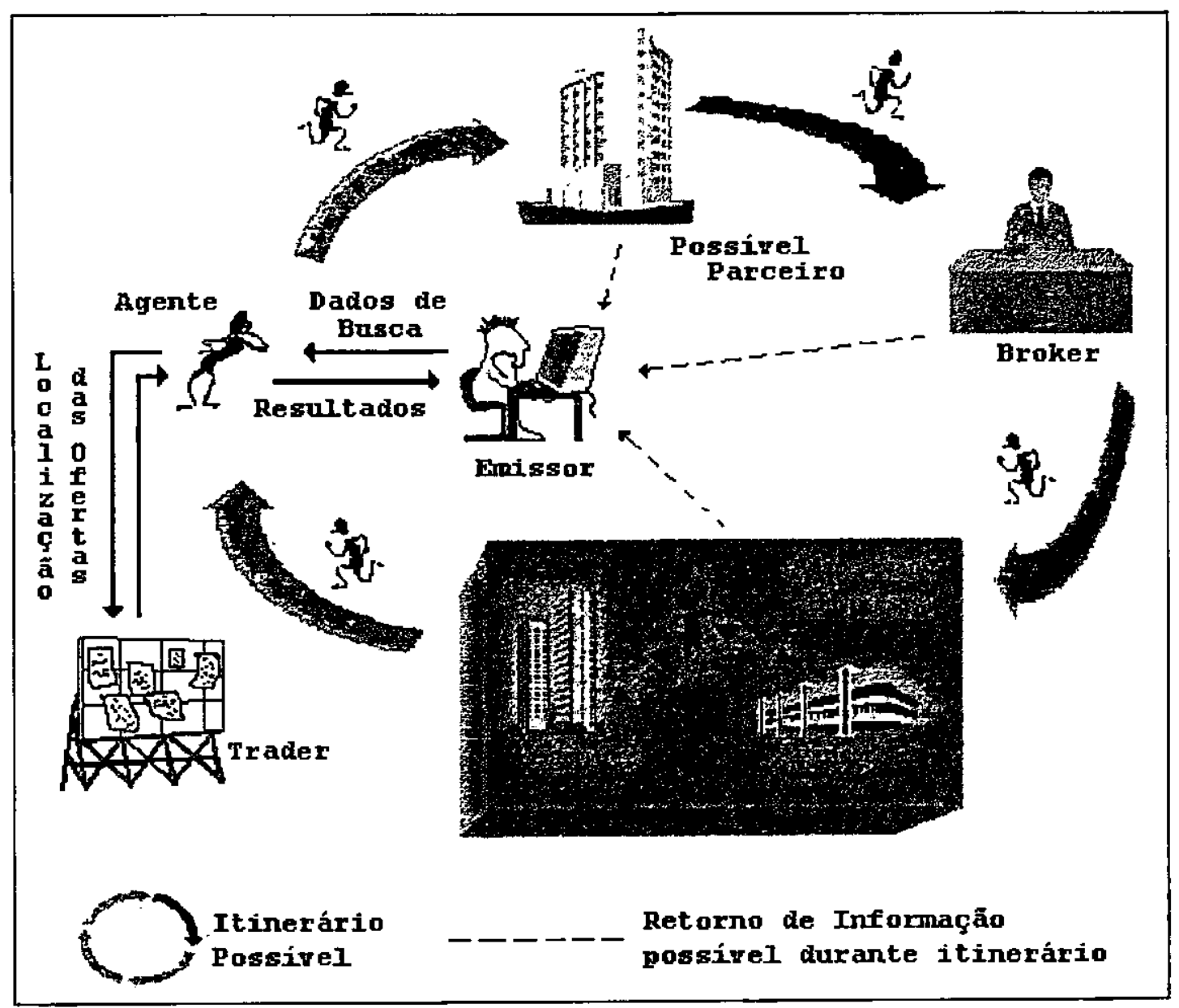

Figura 3.9. Cenário da busca por competências relevantes à exploraçăo da oportunidade na intenção de encontrar parceiros em potencial para formar uma EV

\section{Sumário}

Os Sistemas de informação tem crescido continuamente, em importância e serviços oferecidos. Os serviços operados sobre redes de computadores tem acompanhado esse crescimento, fornecendo facilidades para as empresas conseguirem realizar seus projetos com sucesso. Para que os serviços possam continuar surgindo e melhorando, a infra-estrutura de apoio precisa estar, da mesma forma, se desenvolvendo. A partir do surgimento das tecnologias em infra-estruturas os serviços são criados e disponibilizados ao mercado. Muito tem sido feito nesse sentido, e muito ainda será realizado. 
A Internet incrementou o potencial dos sistemas de informação, dando-lhes mais alcance. Dessa forma, suas capacidades aumentaram, tendo à disposição um ambiente mundialmente aberto, o que os tornou ainda mais interessantes. Por outro lado, a abertura que sua adesão à Internet lhes proporcionou tornou-os também mais vulneráveis. Não se pode dizer que os sistemas fechados estavam livres de ataques, mas esses tinham que ser realizados internamente, o que limitava o conjunto de possibilidades e de possiveis suspeitos. Tais suspeitos podiam ser listados a partir do controle das pessoas que ali estivessem. Com o uso da Internet as possibilidades de ataques crescem de forma descontrolada, podendo ser realizados a partir de inúmeros equipamentos à ela conectados, de diferentes partes do mundo. O número de possiveis suspeitos cresce com semelhante taxa, podendo ser qualquer pessoa que tenha acesso à Internet. As EV's têm na Internet um meio de comunicação barato e eficiente entre suas empresas participantes, bem como um ótimo meio de divulgação de seus serviços e busca de novas oportunidades e parceiros. Entretanto a preocupação com possiveis ataques também fazem parte do seu cotidiano. Neste trabalho tratamos os ataques como intrusões, e a seguir falamos mais a respeito dessas intrusões e algumas formas de impedir que sistemas sejam afetados por elas.

\subsection{Intrusão}

Intrusão pode ser definida como: "Um conjunto de ações que tentam comprometer a integridade, confidencialidade ou disponibilidade de recursos" (Crosbie \& Spafford 1995; Zamboni et al. 1998) e pode se caracterizar de duas formas diferentes:

- Acesso não autorizado a sites, incluindo seus sistemas e seus equipamentos;

- Interceptação de mensagens em trânsito nas redes de computadores;

Os acessos não autorizados a sites podem acontecer via RC's (com o intruso acessando o sistema a partir de um ponto possivelmente fora das instalações) ou fisicamente aos equipamentos do site (ex. o intruso entra na empresa e desliga um servidor). Gerentes de sistemas em todo o mundo trabalham constantemente para evitar que seus sites sejam invadidos. $\mathrm{Na}$ invasão do sistema pelas RC's o intruso pode conseguir, de alguma forma, acesso adquirindo privilégios de usuários 
comuns, e algumas vezes (principais tentativas), de super-usuários. A partir daí podem realizar inúmeras ações com os dados do sistema em questão. Uma maneira bastante utilizada no sentido de tentar manter um site seguro é através do uso de "firewalls" (Bonifácio 1997), cujo objetivo é barrar o intruso na "porta" do sistema antes que ele possa efetuar qualquer tipo de dano.

A interceptação de mensagens é feita através dos meios de comunicação. A mensagem é interceptada enquanto trafega de sua origem para seu destino, e uma vez de posse da informação pode-se realizar diferentes ações de acordo com a conveniência do intruso. As interceptações de mensagens podem ocorrer de duas formas distintas (Tanenbaun 1996), ilustradas na figura 4.1:

- Intrusão Passiva (aquela que apenas lê os dados, sem alterá-los);

- Intrusão Ativa (aquela que lê os dados corretos, os altera e os coloca de volta para serem propagados pela rede).

$\mathrm{Na}$ intrusão passiva não são causados danos aos dados ou às mensagens. O intruso se limita a conseguir o acesso e observar o que está acontecendo, sem lhe impor qualquer tipo de alteração. É o tipo clássico de espionagem (ex. industrial e militar, como mencionado no capitulo 2). 0 espião então invade algum sistema, ou intercepta alguma mensagem, e decide o que fazer, o que se torna perigoso e/ou inaceitável quando o segredo dos dados é fundamental. No caso de espionagem industrial, por exemplo, um empresário espião pode tomar a frente de um concorrente roubando-lhe uma idéia inovadora. Para as EV's esse aspecto pode se tornar extremamente importante aos seus interesses (ex. para que a empresa consiga terminar um projeto e lançar um produto novo no mercado. Se outras empresas obtiverem informações a respeito do projeto antes do seu lançamento, passa a existir o risco delas lançarem o produto antes daquela que teve a idéia originalmente). No caso militar pode-se descobrir um plano inimigo e obter vantagem sobre ele. 


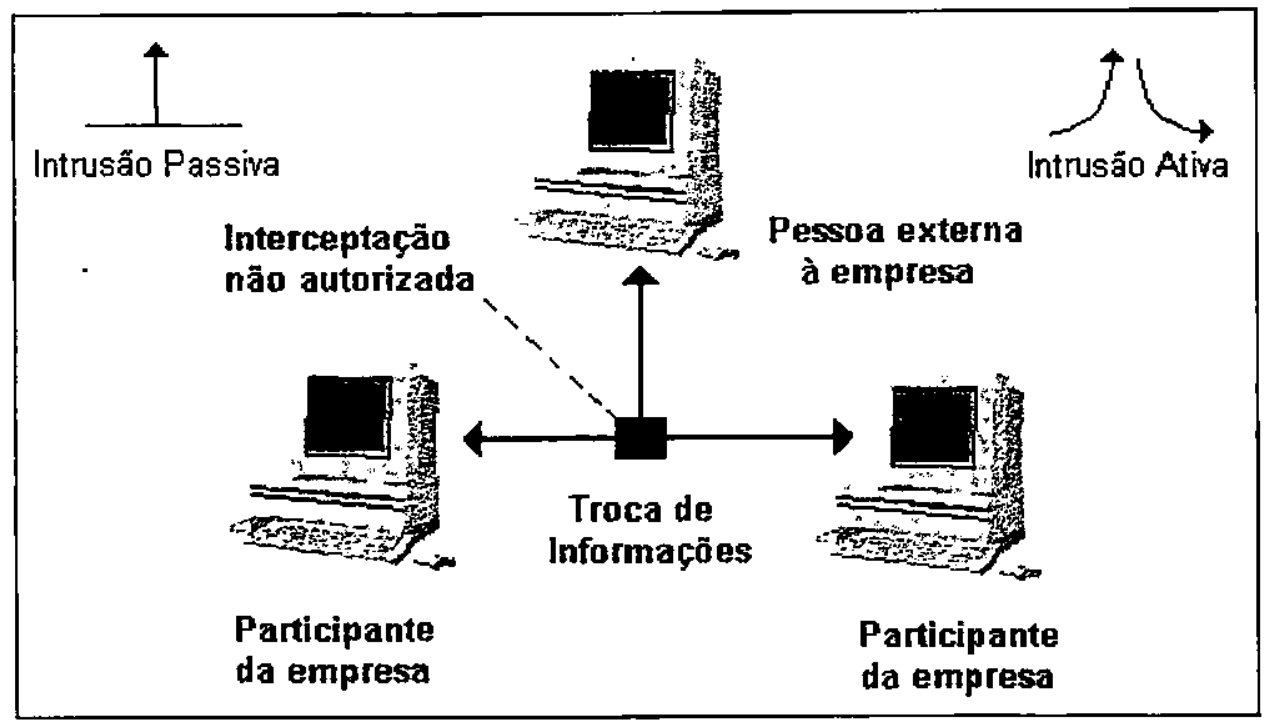

Fig. 4.1 - Intrusão em transferência de dados

$\mathrm{Na}$ intrusão ativa, por outro lado, o intruso obtém os dados e mensagens e os altera de acordo com o que lhe convém. É o tipo clássico de sabotagem - que também pode ser utilizado na disputa industrial ou militar. O objetivo é alterar os dados enviados a fim de que no destino sejam recebidos dados incorretos. Em um exemplo de sabotagem industrial podemos citar a alteração de uma mensagem enviada, de forma que a especificação para a produção de uma determinada peça chegue alterada ao destino causando produção errada. E como exemplo de sabotagem militar podemos citar a alteração de uma mensagem fazendo com que toda uma tropa se dirija ao local errado, ou ainda, invadindo o sistema inimigo, alterar os dados de estoque ou de planos.

Para controle de segurança, tanto relacionado à invasão de sistemas quanto à transferência dos dados, assumimos que a informação está segura se apresenta (Tanenbaun 1996; Bosselaers et. al. 1995):

- Confidencialidade - manter a informação fora do alcance de usuários não autorizados;

- Autenticação - determinar quem é o usuário antes de lhe disponibilizar informação;

- Não Repúdio - uso de assinatura a fim de provar que um usuário realmente enviou determinada mensagem e em um determinado tempo, não permitindo que ele negue a ação;

- Controle de Integridade - garantir que uma mensagem recebida é exatamente a mesma enviada e não uma modificação realizada por um intruso durante sua transferência. 
O uso das RC's traz à estrutura da empresa diferentes tipos de vulnerabilidades que devem ser atacadas pelo gerente do seu sistema. Essas vulnerabilidades podem abrir caminho para que o sistema da empresa seja invadido e prejudicado por usuários externos, e até mesmo por usuários internos. No item 4.2 apresentamos melhor esses aspectos.

Com a intenção de garantir a segurança desejável às transações através das RCs é cada vez mais estudado, elaborado e utilizado o método da criptografia. Existem várias formas de criptografia, ou formas de usá-la. Neste trabalho será apresentada a criptografia, com algumas formas básicas e algumas mais importantes atualmente. Dentre elas estão: Introdução à Criptografia Tradicional, criptografia por Substituição de Cifras, por Transposição de Cifras, "One-Time Pads", Princípios Fundamentais da Criptografia, algoritmos com Chave Secreta, DES, algoritmos com Chave Pública, o algoritmo RSA, etc. Também fará parte do trabalho um estudo sobre Assinaturas

Digitais (Lecture Notes 1997) incluindo assinaturas com Chave Secreta e assinaturas com Chave Privada.

Existem vários protocolos especificados e implementados para transferência de dados. Como TCP/IP, HTTP, etc. Existem também protocolos implementados com preocupação a respeito dos problemas de segurança como SSL, SHTTP, IPv6, SET, etc. Esses protocolos serão apresentados neste trabalho.

Existem também técnicas de gerenciamento que procuram otimizar a segurança no sistema, como é o caso da "Single Sign-On" que se preocupa com a quantidade de comunicações levando senhas de usuários pela rede. Esse tipo de comunicação torna maior o risco de alguém conseguir acesso a essas senhas de forma indevida, e também será apresentada neste trabalho.

\subsection{Avaliação de Vulnerabilidades em Sistemas de Informação}

Existem diferentes pontos de vulnerabilidade que podem representar prejuizos à empresa quando atacados pelos intrusos:

- protocolos

- desvio

- perda de propriedade intelectual 
- cópia ilegal

- vírus

\subsubsection{Protocolos}

Um ponto de grande vulnerabilidade nos sistema para as empresas é o protocolo de comunicação que usam para conectarem seus serviços de rede. A interceptação de mensagens ocorre nesses protocolos, responsáveis por sua transmissão. Os protocolos mais comuns e mais utilizados na Internet são:

\subsubsection{TCP/LP}

(Transfer Control Protocol/Internet Protocol) - O modelo de referência TCP/IP foi usado na predecessora de todas as redes de computadores - ARPANET - e por sua sucessora - Internet. A ARPANET era uma rede de pesquisa sem controle central, devido à Guerra Fria, para que o inimigo não pudesse inutilizar a rede bombardeando um ponto qualquer, mantida pelo DoD (US Department of Defense - Departamento de Defesa dos Estados Unidos). Centenas de universidades e instalações do governo eram conectadas através dessa rede usando lentas linhas telefônicas. Quando redes de satélite e rádio foram adicionadas, os protocolos existentes tiveram problemas em interagir com elas, tornando necessário um novo modelo de referência. A capacidade de conectar múltiplas redes foi um dos principais objetivos desde o princípio. Essa arquitetura ficou conhecida mais tarde como modelo de referência TCP/IP (Tanenbaun 1996).

A idéia do TCP é a de prover uma transmissão confiável ponto a ponto sobre uma rede não confiável. A transmissão realizada usando esse protocolo é orientada a conexão (o que não é o caso do UDP - "User Datagram Protocol" - que é não orientada a conexão). Toda máquina que suporta TCP possui uma entidade de transporte TCP que faz interface com a camada IP. Os pacotes TCP são encapsulados em pacotes IP que são transportados pela rede, e ao chegarem ao destino são desencapsulados e repassados para a camada TCP. Todo o tratamento de confiabilidade dos dados é feito em nível de TCP, e essa confiabilidade é apenas para verificação de perda de dados. No caso de algum desses pacotes se perderem, ao remontar a mensagem o TCP cuida para que o pacote perdido seja novamente enviado, garantindo o recebimento da 
mensagem sem perda. Entretanto, caso uma mensagem seja interceptada no meio de sua transmissão e trocada por outra, o receptor não tem como saber, uma vez que, a camada TCP receberá a mensagem trocada completa.

O TCP/IP foi criado em uma época e lugar em que segurança não era um conceito muito forte. A ARPANET consistia de muito poucos hosts, todos sites acadêmicos, grandes corporações ou governo. Todos conheciam a todos, e entrar na Internet não era fácil. $O$ ajuste do protocolo TCP/IP foi bom (funciona até hoje), mas não possui provisões reais para segurança (i.é. autenticação, verificação, criptografia). Fazer Spoofing de pacotes, interceptação de pacotes, leitura de dados, é mais fácil na Internet atual. O TCP/IP não provê qualquer tipo de segurança à mensagem contra intrusões, como métodos de criptografia. Assim, quem interceptar uma mensagem passada através do protocolo TCP/IP, enxergará os dados de forma clara, ou seja, não codificada, e conseguirá facilmente entender o que o autor escreveu e enviou através da rede.

Os ataques mais comuns são de negação de serviço (denial of service), seguidos por sniffing de pacotes, scanning de portas, e outras atividades relativas (Seifried, 1999).

\subsubsection{HTTP}

(HyperText Transfer Protocol) - é um protocolo em nível de aplicação para distribuição e colaboração em sistema de informação hipermídia. É um protocolo genérico orientado a objetos, que pode ser usado para muitas tarefas, incluindo servidor de nomes a sistemas de gerenciamento de objetos distribuídos, através da extensão de seus métodos de requerimento. Assim como o TCP não oferece nenhuma proteção contra intrusão, deixando fácil o entendimento dos dados transmitidos através dele. O HTTP tem estado em uso pelo sistema de informação global WWW (World Wide-Web) desde 1990.

\subsubsection{Desvio}

Uma nova forma de vulnerabilidade em crescimento atualmente na WWW é o desvio. Com isso consegue-se desviar acessos direcionados a determinados sites para sites diferentes. Assim podese enganar as pessoas que tentam o acesso prejudicando-as ou prejudicando os sites originais, 
que acabam tendo publicada uma imagem ou informações que não aquelas intencionadas por eles, além de poderem perder clientes, no caso de se tratarem de sites comerciais, por exemplo.

\subsubsection{Perda de propriedade intelectual}

É um grande problema para aqueles que criam um produto e pretendem lançá-lo no mercado. Pode acontecer que antes de conseguirem lançar o produto, algum concorrente tenha conseguido a idéia através de meios escusos e acabe lançando primeiro, ou ainda, que consiga patentear antes do criador original. Esses meios escusos podem ser através de intrusões como as citadas acima.

\subsubsection{Cópia ilegal}

A cópia ilegal também pode ser conseguida através de intrusões, como a perda de propriedade intelectual. A diferença entre as duas se consiste do fato de neste caso a propriedade intelectual já estar assegurada ao criador, porém esse perde muito com cópias feitas de seus produtos sem que lhe seja pago nada por isso. Quando alguém lança um produto no mercado a idéia é justamente receber por ele, a menos que o próprio criador tenha a intenção de distribui-lo livremente. Quando a cópia é feita ilegalmente, ou seja, sem a autorização do autor, isso acaba por prejudicá-lo.

\subsubsection{Virus}

Um grande problema atual em sistemas computacionais são os vírus. Esse problema não é simples, pois estão sempre surgindo vírus novos e quanto mais pessoas tiverem acesso ao sistema, maior a vulnerabilidade à infecção. Os vírus podem infectar o sistema através de um disquete inserido em um micro ligado a ele, ou através das redes como o acesso à Internet. Como a Internet atualmente permite acesso a uma quantidade e variedade grande de sites, e muitos deles nos oferecem aplicativos e outros tipos de arquivos, não é difícil encontrar e acessar um infectado com algum tipo de vírus. 
Atualmente os vírus não atacam somente em forma de aplicativos executáveis que podem ser muito prejudiciais ao sistema. Eles atacam também como macros que alteram documentos, e sua variedade é cada vez maior.

A realidade é que existe uma corrida em volta dos vírus. De um lado há aqueles que desenvolvem os virus, seja por diversão, por sabotagem ou por qualquer outro motivo. $E$ do outro lado há aqueles que desenvolvem os aplicativos capazes de reconhecê-los e destruí-los. Os vírus constituem um grande perigo para um sistema, uma vez que são capazes de destruí-lo ou às suas informações.

Nenhum sistema ligado hoje à Internet está totalmente livre dessas vulnerabilidades. $\mathrm{O}$ que o gerente de cada sistema deve fazer é procurar o que estiver ao seu alcance para realizar uma boa proteção do seu sistema, de acordo com suas características próprias. Essa é uma tarefa que diversos gerentes têm batalhado para realizar.

\subsection{Contra Medidas de Proteção}

As contra medidas são criadas e desenvolvidas no intuito de impedir as intrusões aos sistemas, seja pela invasão direta de seus sites ou pela interceptação de suas mensagens. Através das contra medidas pretende-se envolver e minimizar tanto quanto possível as vulnerabilidades do sistema.

A Criptografia, a Assinatura Digital e os Certificados Digitais foram desenvolvidos para evitarem intrusões, e formam uma base importante para o desenvolvimento de vários tipos de contra medidas criadas e utilizadas pelos gerentes de sistemas no intuito de mantê-los sempre seguros.

\subsubsection{Criptografia}

A definição de criptografia, segundo o dicionário da língua portuguesa é: "1.Arte de escrever em cifra ou em código; 2. Conjunto de técnicas que permitem codificar escritas" (Ferreira 1998) 
A criptografia é antiga, surgida na época de César, da Roma antiga, para enviar mensagens a suas tropas sem que o inimigo pudesse entendê-las caso a interceptassem (Tanenbaun 1996). Em 1518, Johannes Trithemius, um monge beneditino, publica a primeira obra cientifica sobre Criptografia, "é a ciência que trata do estudo de codificação informações de forma a permitir que somente pessoas autorizadas ao acesso à elas possam decodificá-las” (RSA 1998b).

A criptografia usada por César era simples, baseada no que ficou conhecido como "A Roda de César". Era composta por dois discos de tamanhos diferentes sobrepostos no mesmo centro. Em ambos os discos haviam todas as letras do alfabeto. A princípio cada letra de um disco se encontrava junto à sua mesma imagem no outro disco. Era então escolhida uma "chave" baseado na qual um disco era girado enquanto o outro permanecia fixo. Caso a chave escolhida fosse o número 3, o disco que girava o fazia por três casas, fazendo então as correspondências entre as letras (A passaria a ser representada por D, B por E, C por F e assim por diante). O general que receberia a mensagem possuía uma roda igual e deveria saber a chave para conseguir decifrar a mensagem enviada.

Atualmente existem vários tipos e algoritmos de criptografia.

\subsubsection{Introdução à Criptografia Tradicional}

Será feita uma breve introdução a respeito da criptografia tradicional. Para saber mais a respeito deixo recomendado (Kahn 1967), seguindo a recomendação de (Tanenbaun 1996).

Historicamente, grupos de pessoas como militares, diplomatas e amantes têm usado e contribuído bastante para a arte da criptografia. Dentre eles, o grupo dos militares tem sido o mais importante, devido ao grande investimento em pesquisas e tecnologias que pudessem garantir superioridade bélica e estratégica sobre $o$ inimigo em uma eventual guerra, principalmente pelas superpotências, e durante o período da "Guerra Fria". Evitar espionagem e sabotagem inimiga, e ao mesmo tempo espionar e/ou sabotar o inimigo, era um grande objetivo dentro de uma estratégia de guerra, e o sucesso desse objetivo se tornaria um grande trunfo, quando não a determinação do vencedor da guerra. 


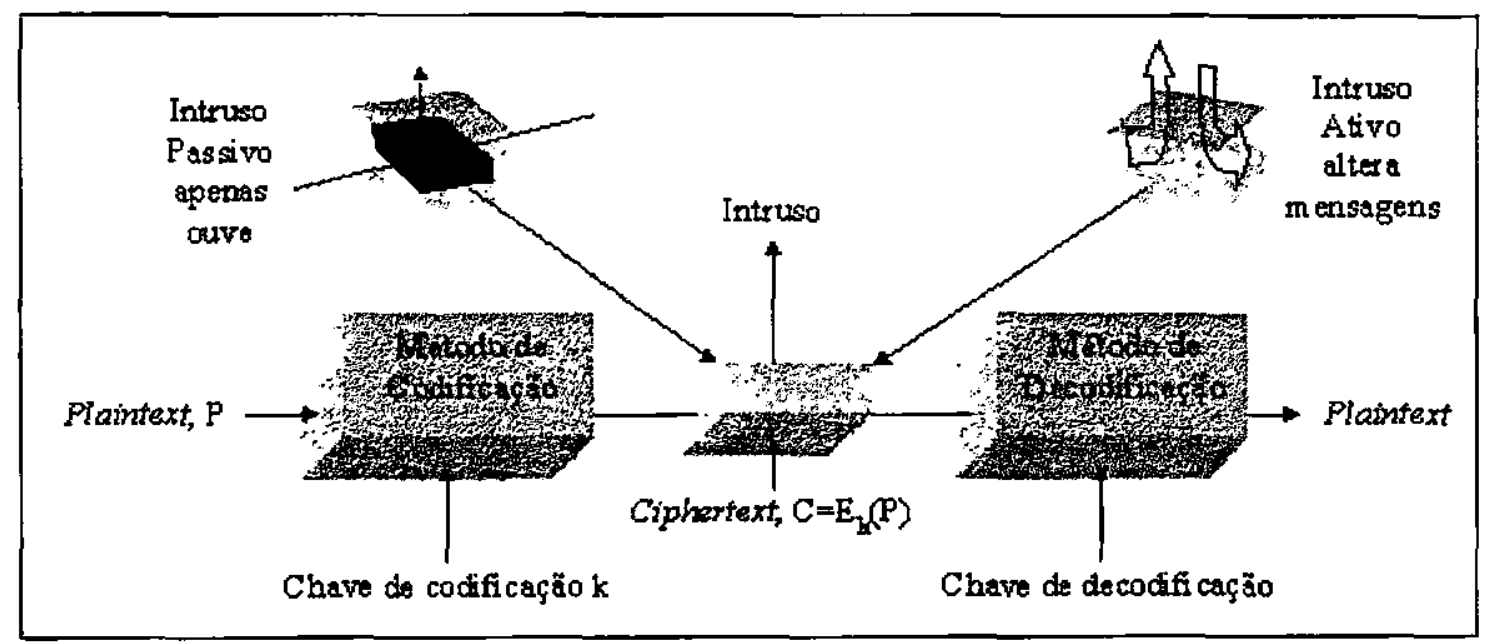

Fig. 4.2 - O modelo do Processo de Criptografia (Tanenbaun 1996)

Antes dos computadores, um dos maiores problemas era a habilidade exigida ao homem para realizar as transformações necessárias, ainda mais no campo de batalha com pouco equipamento. As mensagens a serem codificadas, conhecidas como o "plaintext", são transformadas por uma função parametrizada por uma chave. A saída do processo de criptografia, conhecida como “ciphertext" (fig. 4.2), é então transmitida. Dessa forma, mesmo que um intruso capte a mensagem, sem conhecer a chave para sua decodificação, não poderá entendê-la facilmente.

A arte de quebrar cifras, ou mensagens codificadas, é chamada de "Criptoanálise". A arte de produzir as cifras (criptografia) e de quebrá-las (criptoanálise) é coletivamente conhecida como "Criptologia".

Vamos assumir uma notação para relacionar "Plaintexts", "Ciphertexts" e chaves. Diremos que $C=E_{k}(P)$ significando que o "plaintext" $P$, usando a chave $k$ gera o "ciphertext" $C$. Analogamente, $P=D_{k}(C)$ representa a decodificação de $C$ a fim de se obter $P$ novamente. Dessa forma:

$$
D_{k}\left(E_{k}(P)\right)=P
$$

Essa notação sugere $E$ e $D$ como funções matemáticas. Essas funções são, entretanto, de dois parâmetros, um dos quais (a chave $k$ ) está mostrado de forma subscrita.

$\mathrm{Na}$ criptografia os métodos usados não costumam ser secretos. Caso a confiabilidade na criptografia dependesse da garantia de segredo do método usado, cada vez que surgissem Suspeitas de comprometimento em relação ao método em uso, esse teria que ser trocado, o que 
causaria grandes transtornos. E para o caso de se acreditar que o segredo estaria totalmente guardado e seguro não corresponder à verdade, ou seja algum intruso estar de posse desse segredo, isso poderia causar mais danos do que beneficios.

Aí está então um bom motivo para o uso das chaves. A chave geralmente consiste de uma string

(relativamente) pequena que seleciona uma entre muitas criptografias possíveis. Ao contrário do método que pode-se alterar somente em alguns anos, a chave pode ser alterada sempre que desejado. Dessa forma o método em si é público, e o que garante a confiabilidade na criptografia é uma chave secreta e que pode ser facilmente trocada.

O grande segredo na criptografia está realmente na chave, e seu tamanho é de vital importância. $\mathrm{O}$ tamanho da chave define o número de combinações possíveis para sua formação. Usando chave de dois dígitos numéricos, por exemplo, deixa 100 combinações possíveis (de 00 a 99). Com o uso de três dígitos esse número cresce para 1000 combinações. Ou seja, quanto maior o tamanho da chave, maior o trabalho que o criptoanalista terá para lidar com ela.

Os métodos de criptografia têm sido historicamente divididos em duas categorias: Substituição de Cifras e Transposição de cifras.

\subsection{Substituição de Cifras}

Nesse método cada letra ou conjunto de letras é substituído por outra letra ou outro conjunto de letras. Um grande e antigo exemplo desse método é a Roda de César (descrita acima neste capitulo). A Roda de César entretanto usava uma chave ' $k$ ', e o código relativo a uma determinada letra no "plaintext" era sempre a letra que ficava ' $k$ ' posições a frente no alfabeto da letra original.

Outra abordagem tomada na categoria de substituição de cifras foi a de mapear as letras em outras escolhidas aleatoriamente. Por exemplo:

plaintext: $\quad$ a $\begin{array}{lllllllllllll}\text { ciphertext } & \mathrm{M} & \mathrm{U} & \mathrm{X} & \mathrm{A} & \mathrm{L} & \mathrm{O} & \mathrm{D} & \mathrm{T} & \mathrm{S} & \mathrm{R} & \mathrm{B} & \ldots\end{array}$

Ex: cadeia $\rightarrow$ XMALSM

\subsection{Transposição de Cifras}


O método da substituição de cifras preserva a ordem dos símbolos do "plaintext" alterando-os. O método da transposição de cifras, por sua vez, reordena as letras sem alterá-las. Vejamos um exemplo (fig 4.3):

$\begin{array}{llllllll}\text { B } & \text { E } & \text { L } & \text { O } & \text { N } & \text { G } & \text { A } & \text { Plaintext: } \\ 2 & 3 & 5 & 7 & 6 & 4 & 1 & \text { Pequenotextoexemploparacriptografia } \\ \text { p } & \text { e } & \text { q } & \text { u } & \text { e } & \text { n } & \text { o } & \\ \text { t } & \text { e } & \text { x } & \text { t } & \text { o } & \text { e } & \text { x } & \text { Ciphertext: } \\ \text { e } & \text { m } & \text { p } & \text { l } & \text { o } & \text { p } & \text { a } & \text { OXATAPTEROEEMAGNEPPIQXPCREOOIFU } \\ \text { r } & \text { a } & \text { c } & \text { r } & \text { i } & \text { p } & \text { t } & \text { TLRA } \\ \text { o } & \text { g } & \text { r } & \text { a } & \text { f } & \text { i } & \text { a } & \end{array}$

Fig. 4.3 - Exemplo de Transposição de Cifras

O funcionamento se dá da seguinte forma:

- Escolhe-se como chave uma palavra sem letras repetidas (no nosso caso BELONGA);

- Numera-se as letras da palavra de acordo com a ordem das mesmas no alfabeto;

- Escreve-se a mensagem sob as letras da palavra chave;

- Copia-se então para o "ciphertext" as colunas de acordo com os números das letras da palavra chave.

\subsection{One-Time Pads}

Criptoanalistas analisam freqüências de letras e possíveis palavras relevantes ao assunto da mensagem a fim de quebrar os dois métodos de criptografia descritos acima. Um modo de criar a cifra inquebrável é conhecido como "One-Time Pads". Primeiro se escolhe uma cadeia de bits randômica como chave. Então converte-se o "plaintext" a uma cadeia de bits, por exemplo usando seus códigos ASCII. Por fim computa-se o "OU EXCLUSIVO" dessas duas cadeias, bit a bit. $\mathrm{O}$ "ciphertext" resultante não pode ser quebrado, porque cada "plaintext" possivel é igualmente provável candidato.

Esse método tem algumas desvantagens, como o fato de a chave não poder ser memorizada. Assim ambos (quem envia e quem recebe) deve manter uma cópia escrita consigo, o que seria muito ruim em caso de captura de um dos dois. 


\subsubsection{Dois Princípios Fundamentais da Criptografia}

Há dois princípios da criptografia que devem ser notados antes da apresentação de outros sistemas de criptografia, pois definem cuidados a serem tomados com a intenção de garantir o sucesso de qualquer um deles.

O primeiro princípio diz que todas as mensagens codificadas precisam conter alguma redundância, ou seja, informação não necessária ao entendimento da mensagem, para dificultar a decodificação por algum intruso. A redundância torna mais dificil para o criptoanalista enxergar algum sentido no código codificado.

O segundo princípio diz que algumas medidas devem ser tomadas para prevenir que intrusos ativos retornem mensagens antigas. Digamos que algum intruso ativo armazene mensagens válidas e comece a reenviá-las repetidamente. Poderia gerar, por exemplo, excesso de pedidos iguais a uma empresa de entrega. Para contornar esse problema uma solução seria anexar a cada mensagem um "timestamp" (selo de tempo) válido somente por um tempo determinado. Dessa forma, ao receber uma mensagem, essa é guardada pelo tempo de validade do selo para comparação com possíveis mensagens iguais. Depois desse tempo a mensagem é descartada, e caso alguma mensagem chegue com o selo de tempo já vencido será automaticamente desconsiderada.

\subsubsection{Algoritmos de Chave Secreta}

A criptografia moderna usa os mesmos princípios da tradicional (transposição e substituição), porém com ênfase diferente. Antigamente a idéia era usar algoritmos simples com chaves grandes. Atualmente a tendência é criar algoritmos bastante complexos para que o criptoanalista não consiga ter nenhuma noção de como o algoritmo funciona, mesmo que ele consiga vários pedaços de "ciphertext".

A fim de se criar um algoritmo mais complexo que a simples substituição e a transposição, podemos nos valer da técnica de unir essas duas abordagens. O método da transposição pode ser implementado através de um circuito simples, mostrado a seguir (figura 4.4(a)), conhecido como P-Box. No exemplo da figura 4.4, dando às linhas de entrada índices 01234567 no sentido de cima para baixo, a saída seria 46705312 . O método da substituição pode ser implementado por um circuito conhecido como S-Box (fig. 4.4(b)). No exemplo abaixo tem-se como entrada um "plaintext" de 3 bits e como saída um "ciphertext" também de 3 bits. Os 3 bits de entrada selecionam uma das 8 linhas de saida do decodificador atribuindo-lhe o valor 1 e atribuindo o 
valor 0 para as outras 7 linhas. A partir daí é usado um circuito P-Box cuja saída é novamente codificada em 3 bits. Como exemplo vamos supor a entrada dos números 01234567 nessa ordem. A saída seria 36750412 .

Essas duas abordagens apresentadas são eficientes no que diz respeito ao tempo, mas são de fácil entendimento, tornando fácil também o trabalho do criptoanalista. É possível enxergar o poder desses elementos básicos quando começamos a uni-los em cascata (fig. 4.4(c)), passando a constituir o que é conhecido como "Product cipher". Unindo esses dois elementos temos um algoritmo eficiente também quanto à complexidade. No exemplo mostrado na figura 4.4(c) temos uma entrada de 12 bits que passará por sucessivas transposições e substituições até a saida também de 12 bits. Durante as substituições, para se evitar a necessidade de um circuito capaz de mapear 12 bits (o que exigiria o uso de $2^{12}$ linhas de ligação), essa etapa foi dividida em quatro circuitos S-Boxs com cada um tratando separadamente 3 linhas. Nessa abordagem de "Product cipher" quanto mais estágios forem colocados mais complicada será a função de saída, dificultando o trabalho do criptoanalista.

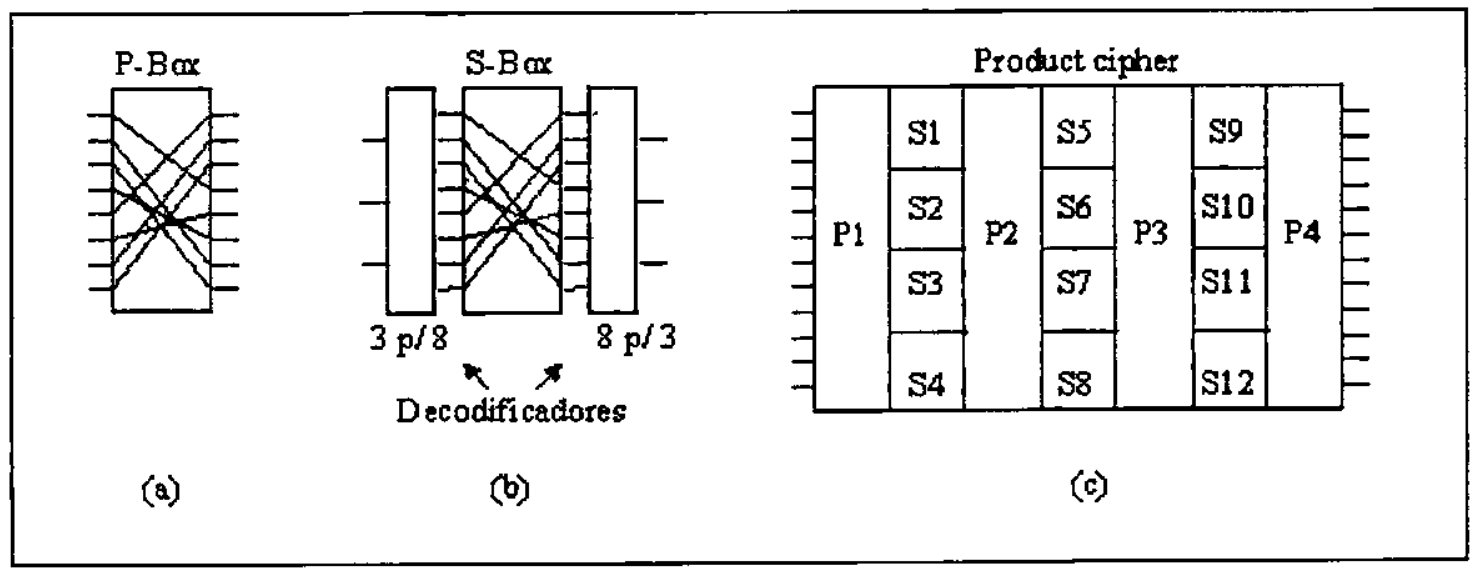

Fig. 4.4 - Elementos básicos de "Product ciphers". (a) P-Box. (b) S-Box. (c) Product (Tanenbaun 1996)

\subsection{DES}

O governo dos Estados Unidos adotou em janeiro de 1977 um "Product cipher" desenvolvido pela IBM como padrão oficial. A indústria adotou amplamente esse padrão, o DES ("Data Encryption Standard'), em produtos de segurança. Ele não é muito seguro em sua forma original (Wayner 1995), mas aceitável em uma versão modificada (Tanenbaun 1996). 
O DES usa um algoritmo de 19 estágios (figura 4.5(a)), usando chave de 56 bits, codificando o "plaintext" em blocos de 64 bits gerando um "ciphertext" também de 64 bits. Vejamos uma pequena descrição do algoritmo e seus estágios:

O primeiro estágio é uma transposição no "plaintext" independentemente da chave. O último estágio é exatamente o inverso dessa transposição. O penúltimo estágio troca os 32 bits mais a esquerda com os 32 mais a direita. Os outros 16 estágios são idênticos, porém cada qual parametrizado por funções diferentes em relação à chave. Esse é um algoritmo em que a decodificação é realizada com a mesma chave que a codificação, seguindo os passos na ordem inversa.

A figura 4.5(b) ilustra um dos 16 estágios idênticos, que possuem duas entradas de 32 bits e geram duas saídas de 32 bits. A saída da esquerda é uma simples cópia da entrada da direita, e a saída da direita é o resultado de uma operação de "OU EXCLUSIVO" da entrada da esquerda e de uma função da entrada da direita e da chave para esse estágio, $K_{i}$. A complexidade toda está na função em questão.

Uma chave diferente é usada em cada estágio. Antes do algoritmo começar uma transposição de 56 bits é realizada com a chave. Antes de cada iteração, a chave é dividida em duas unidades de 28 bits, sendo cada uma delas rotacionada para a direita por um número de bits dependente do número da iteração. $K_{i}$ é derivado do resultado dessa rotação com a chave aplicando ainda outra transposição de 56 bits a ela. Um subconjunto de 48 bits é extraído e permutado em cada etapa. 


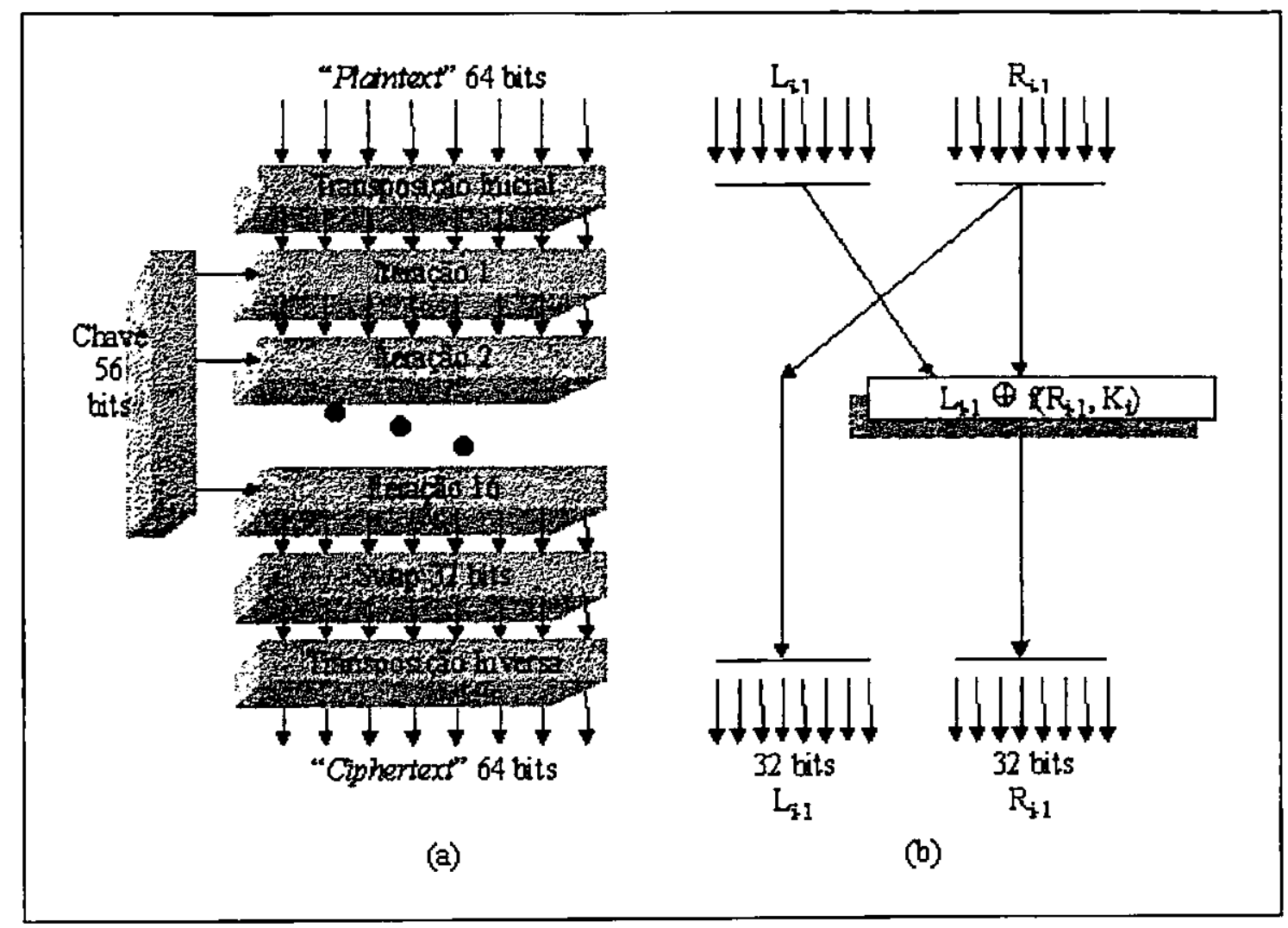

Fig. 4.5 - O padrão de criptografia de dados. (a) Linha geral. (b) Detalke de uma Iteração (Tanenbaun 1996)

A função usada em cada estágio é formada por quatro passos. Primeiro um número de 48 bits, $E$, é construído pela expansão do $R_{i-l}$ de 32 bits de acordo com uma transposição fixa e regras de duplicação. Depois, $E$ e $K$ participam de uma operação de “OU EXCLUSIVO” cuja saída é então dividida em oito grupos de 6 bits cada, sendo cada um deles passados a um S-Box diferente. Cada uma das 64 entradas possíveis em um S-Box é mapeada em uma saída de 4 bits. E, por fim, essas 8 saídas de 4 bits cada $(8 \times 4)$ são passadas por um P-Box.

Há maneiras de quebrar o DES, que não serão explicadas aqui (para saber um pouco mais ver (Tanenbaun 1996)). Vários outros algoritmos de blocos foram propostos, porém o mais interessante e importante após o DES provavelmente é o IDEA ("International Data Encryption Algorith") (Lai et. al. 1990; Lai 1992), que usa uma chave de 128 bits. Não há conhecimento de técnica e não há máquinas atualmente capazes de quebrar o IDEA.

\subsubsection{Algoritmos de Chave Pública}

Um grande problema que sempre esteve relacionado aos métodos de criptografia é o da distribuição da chave a ser usada. Essa chave deveria ser guardada em completa segurança, de 
forma que nenhum tipo de ladrão conseguisse ter acesso. Entretanto ela precisaria ser distribuida de alguma forma àqueles que fossem fazer parte da negociação.

Foi proposto então em 1976 por dois pesquisadores da "Stanford University" (Diffie et. al. 1976) uma abordagem radicalmente nova de criptografia. A proposta tinha como fundamento uma chave para criptografia diferente da chave a ser usada no processo de decodificação, sem que essa fosse resultado de qualquer tipo de derivação da primeira.

Três determinações a serem obedecidas pelo algoritmo de criptografia, $E$, e pelo algoritmo de decodificação, $D$, foram estabelecidas:

1. $D(E(P))=P$

2. É extremamente dificil deduzir $D$ a partir de $E$

3. O algoritmo $E$ não pode ser quebrado por um ataque com um "plaintext" escolhido

Vejamos agora qual é o funcionamento do algoritmo de chave pública:

Imagine uma pessoa chamada Alice querendo receber mensagens seguras, de forma que somente ela consiga ler a mensagem que alguém queira lhe enviar. Alice deve criar um algoritmo para a codificação, $E_{A}$, e um para a decodificação, $D_{A}$. O primeiro algoritmo e uma chave para ele são tornados públicos, de forma que qualquer pessoa seja capaz de saber podendo assim usá-los para enviar uma mensagem para Alice. A única forma de decodificar e entender essa mensagem é através do segundo algoritmo e da chave que somente Alice conhece. Torna-se interessante para ela publicar também o segundo algoritmo a fim de conseguir comentários sobre o mesmo de forma gratuita (fig. 4.6). A segurança é garantida pelo segredo sobre a chave desse segundo algoritmo, $D_{A}$. 


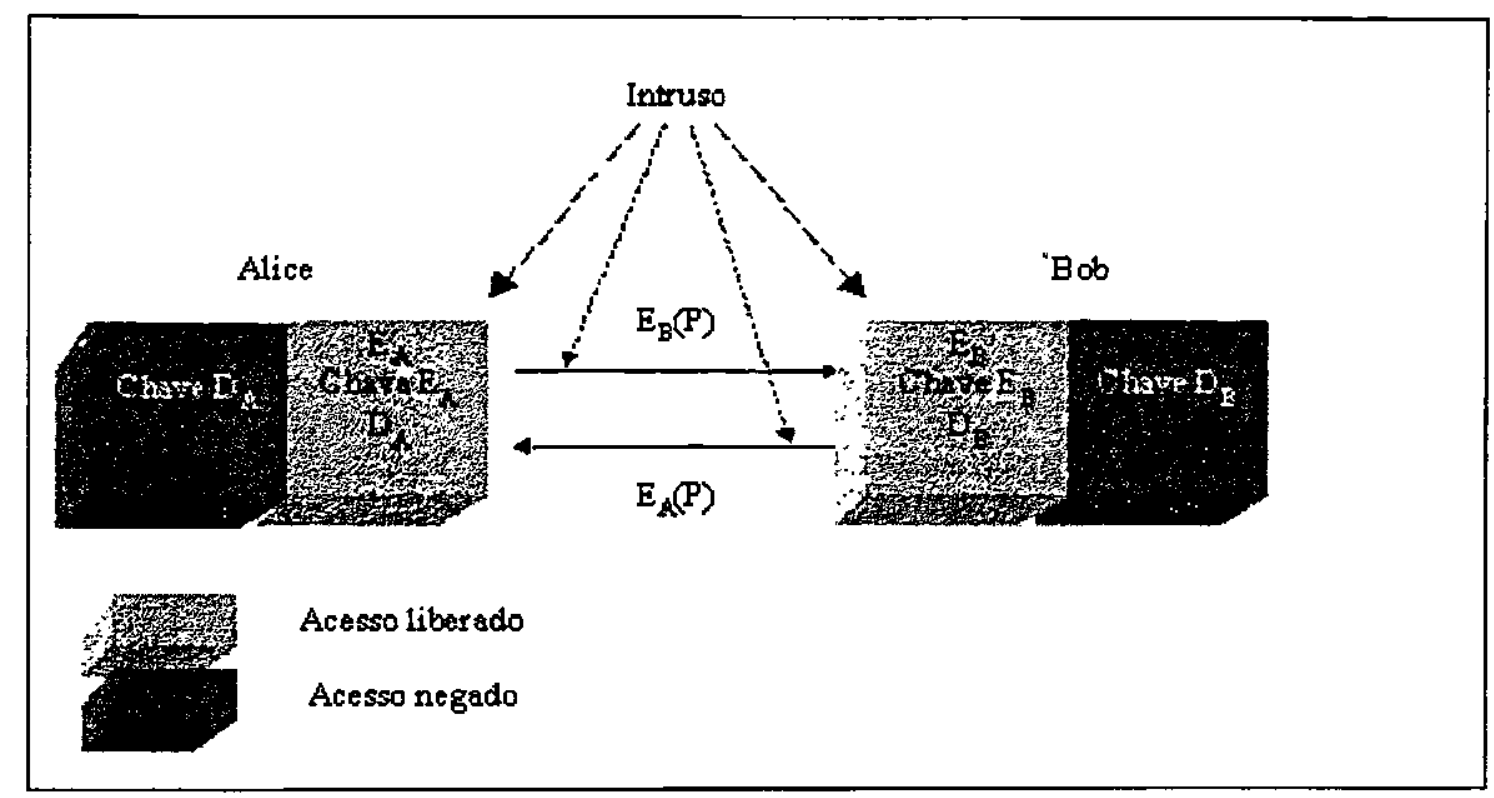

Fig. 4.6 - Modelo de Criptografia com Chave Pública

Dessa forma, todo usuário da rede deve ter uma chave pública e uma chave privada. A pública, a ser disponibilizada a quem quiser saber, de qualquer parte do mundo, a fim de que possam lhe enviar mensagens. E a chave privada, para que somente ele seja capaz de decodificar as mensagens que lhe foram enviadas. Duas pessoas que desejem criar um canal seguro de comunicação entre si, Alice e Bob, precisam apenas descobrir a chave pública um do outro, e o algoritmo escolhido, (o que é fácil, pois fica aberto a qualquer um) e usá-los na mensagem a ser enviada. Ninguém mais, além de Alice e Bob, poderá entender suas mensagens.

Veremos sempre essas chaves referenciadas por chave pública e privada, de forma a diferenciálas da chave secreta do tipo de algoritmo de chave secreta, onde a mesma chave é usada para a codificação e para a decodificação no método de criptografia convencional (conhecida também por criptografia por Chave Simétrica).

\subsection{O Algoritmo RSA}

Pesquisadores têm trabalhado então no desenvolvimento de algoritmos que satisfaçam as três determinações citadas. Em 1978 no M.I.T. três pesquisadores (Rivest, Shamir, Adleman) apresentaram um bom método que ficou conhecido pelas suas iniciais RSA (Rivest et. al. 1978).

Vejamos a seguir uma breve descrição do funcionamento do algoritmo:

1. Escolhe-se dois grandes números primos, $p$ e $q$ (tipicamente maior que $10^{100}$ )

2. Calcula-se $n=p \times q$ e $z=(p-1) \times(q-1)$ 
3. Escolhe-se um número relativamente primo a $z$ e o chama de $d$

4. Encontra-se $e$ tal que $e \times d=1 \bmod z$.

A partir daí podemos dar inicio à criptografia. Divide-se o "plaintext" em blocos, tal que cada mensagem "plaintext", $P$, caia no intervalo $0<=P<n$. Isso pode ser feito agrupando o "plaintext" em blocos de $k$ bits, onde $k$ é o maior inteiro para que $2^{k}<n$ seja verdade.

Para codificar a mensagem, $P$, faça $C=P^{e}(\bmod n)$. Para decodificar $C$, basta fazer $P=C C^{d}(\bmod$ $n)$. Dessa forma a chave pública é composta pelo par $(e, n)$ e a chave privada pelo par $(d, n)$.

A segurança do método é baseada na dificuldade de fatoração de números grandes. Matemáticos têm tentado fatorar números grandes há pelo menos 300 anos, e as evidências continuam apontando esse como um problema extremamente dificil.

Podemos ver na figura 4.7 um exemplo bastante simples ilustrando o algoritmo. Tomemos $p=3$ e $q=11$. Com esses dois números calcula-se $n=33$ e $z=20$. O valor a ser tomado para $d$ pode ser $d=7$. A partir daí $e$ é calculado como $e=3$. A função de codificação assume então a forma $C=P^{3}(\bmod 33)$ e a de decodificação assume a forma de $P=C^{7}(\bmod 33)$. O exemplo mostra a codificação do "plaintext" "SEGURANÇA".

Devido aos números primos escolhidos serem muito pequenos, $P$ precisa ser menor que 33 , fazendo com que cada bloco do "plaintext" contenha apenas um caracter. $\mathrm{O}$ código atribuído a cada caracter é sua posição relativa dentro do alfabeto.

\begin{tabular}{|c|c|c|c|c|c|c|}
\hline \multicolumn{2}{|c|}{ “Plaintext" (P) } & \multicolumn{3}{|c|}{ "Ciphertext" (C) } & \multicolumn{2}{|c|}{ Após decodificado } \\
\hline Símbolo & Código & $\underline{\mathrm{p}}^{3}$ & $\mathrm{P}^{3}(\bmod 33)$ & $\underline{C}^{7}$ & $C^{7}(\bmod 33)$ & Símbolo \\
\hline $\mathbf{S}$ & 19 & 6859 & 28 & $\overline{13492928512}$ & 19 & $\mathrm{~S}$ \\
\hline$E$ & 05 & 125 & 26 & 8031810176 & 5 & $E$ \\
\hline $\mathrm{G}$ & 07 & 343 & 13 & 62748517 & 7 & $\mathrm{G}$ \\
\hline $\mathrm{U}$ & 21 & 9261 & 21 & 1801088541 & 21 & $\mathrm{U}$ \\
\hline $\mathbf{R}$ & 18 & 5832 & 24 & 4586471424 & 18 & $\mathbf{R}$ \\
\hline $\mathbf{A}$ & 01 & 1 & 1 & 1 & 1 & $\mathbf{A}$ \\
\hline$N$ & 14 & 2744 & 5 & 78125 & 14 & $\mathrm{~N}$ \\
\hline Ç & 03 & 27 & 27 & 10460353203 & 3 & Ç \\
\hline A & 01 & 1 & 1 & 1 & 1 & A \\
\hline
\end{tabular}

Fig. 4.7 - Criptografia usando RSA 
Atualmente, entretanto, o RSA é muito lento para a criptografia de grande volume de dados. 0 que acontece então na prática é que a maioria dos sistemas baseados no RSA usam sua criptografia com chave pública para distribuir seguramente chaves secretas para uso com DES, IDEA ou algoritmos similares.

É importante ressaltar que o RSA não é o único algoritmo de chave pública que existe. Outros foram criados, porém não conseguiram o mesmo sucesso.

\subsubsection{Assinatura Digital}

Não deve ser confundida com assinatura digitalizada, pois essas seriam cópias das assinaturas feitas a mão passadas para o computador. A assinatura digital é um pequeno arquivo passado como "attachment" em um documento com a intenção de dar autenticidade ao mesmo (Giel 1997). Quando um documento é trocado por vias comuns (troca de papéis) é essencial o uso de assinaturas dos autores do documento ou daqueles envolvidos no mesmo, afim de garantir sua autenticidade. No meio eletrônico um meio de fazê-lo é usando a Assinatura Digital. Ela é enviada junto com o documento e dá ao seu recebedor a garantia de ser mesmo do remetente identificado.

A Assinatura Digital funciona baseada em algoritmos de criptografia. Ao contrário da assinatura comum, que é praticamente igual para qualquer documento que a pessoa assine, a digital é diferente para cada documento, pois se baseia em uma chave secreta do assinante e no conteúdo do documento em si. Assim, documentos diferentes implicam em assinaturas digitais diferentes, mesmo que sejam do mesmo autor.

As assinaturas digitais são códigos codificados gerados a partir do documento a ser assinado e da chave privada do assinante. A pessoa que recebe o documento pode comprovar a autenticidade da assinatura usando a chave pública do assinante. $O$ sucesso na operação de verificação acontecerá somente se o documento original não tiver sofrido nenhuma alteração.

Assinatura Digital tem a mesma função para mensagens digitais que assinaturas tradicionais (escritas à mão) têm para documentos em papel no caso ideal: prover autenticação de mensagens. São exemplos de áreas de uso de assinatura digital esquemas de pagamento digital, o uso de serviços de rede que não são livres, compra de informação de bases de dados comerciais, comércio eletrônico, etc. (Pfitzmann 1996)

A assinatura digital deve fornecer meios de (Tanenbaun 1996) 
1. recebedor poder comprovar a identidade do emitente;

2. emitente não poder negar o conteúdo da mensagem;

3. recebedor não poder alterar a mensagem recebida.

\subsubsection{Assinaturas com Chave Secreta}

Uma abordagem para assinaturas digitais é através do chamado "Big Brother" (BB). O BB é um tipo de autoridade central em quem todos confiam. Sendo assim, cada pessoa tem uma chave secreta que é confiada ao BB. Ou seja, somente o próprio usuário e o BB conhecem sua chave secreta.

Com essa abordagem, caso um usuário, Alice, queira enviar uma mensagem a outro, Bob, o procedimento seria (figura 4.8):

1. Alice envia uma mensagem endereçada a Bob para o BB, codificada com sua chave secreta;

2. BB decodifica a mensagem que chegou de Alice com a chave secreta dela, que é conhecida apenas pelos dois;

3. BB descobre que a mensagem é para Bob;

4. BB usa a chave secreta de Bob (conhecida somente pelos dois) para lhe enviar a mensagem de Alice codificada, contendo a mensagem original mais a assinatura do BB.

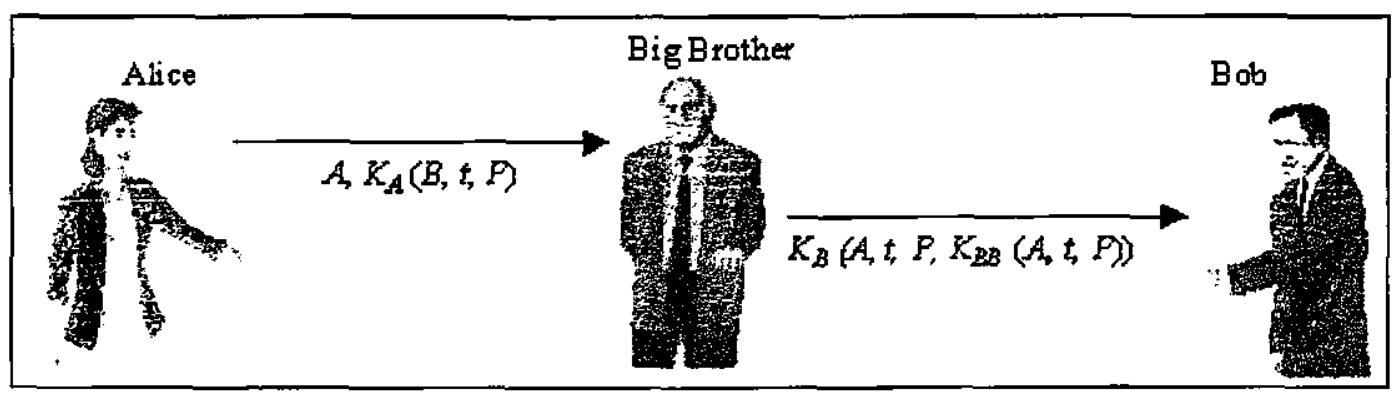

Fig. 4.8 - Assinatura Digital com Chave Secreta (Tanenbaun 1996)

No caso de Alice resolver negar o envio da mensagem, Bob pode apresentar a assinatura do BB provando o envio da mensagem por Alice. Mas quem realmente confirma se Alice enviou ou não a mensagem é o $\mathrm{BB}$, em quem todos confiam.

A confiança que todos devem ter no BB, podendo esse ter acesso a todas as mensagens, não é uma idéia muito bem vinda para as pessoas. Muito melhor seria, se possivel, uma abordagem de assinatura sem a necessidade de tamanha confiança em quem quer que seja. 


\subsubsection{Assinatura com Chave Pública}

A assinatura com Chave Pública contribui bastante para a privacidade total da mensagem, sem que qualquer pessoa, senão o emitente e o recebedor, tenham acesso à ela.

Assumindo que os algoritmos de codificação e decodificação possuam a propriedade $E(D(P))=P$ (como é o caso do RSA), além da básica $D(E(P))=P$, Alice pode gerar $E_{B}\left(D_{A}(P)\right.$ ) para enviar uma mensagem para Bob (figura 4.9).

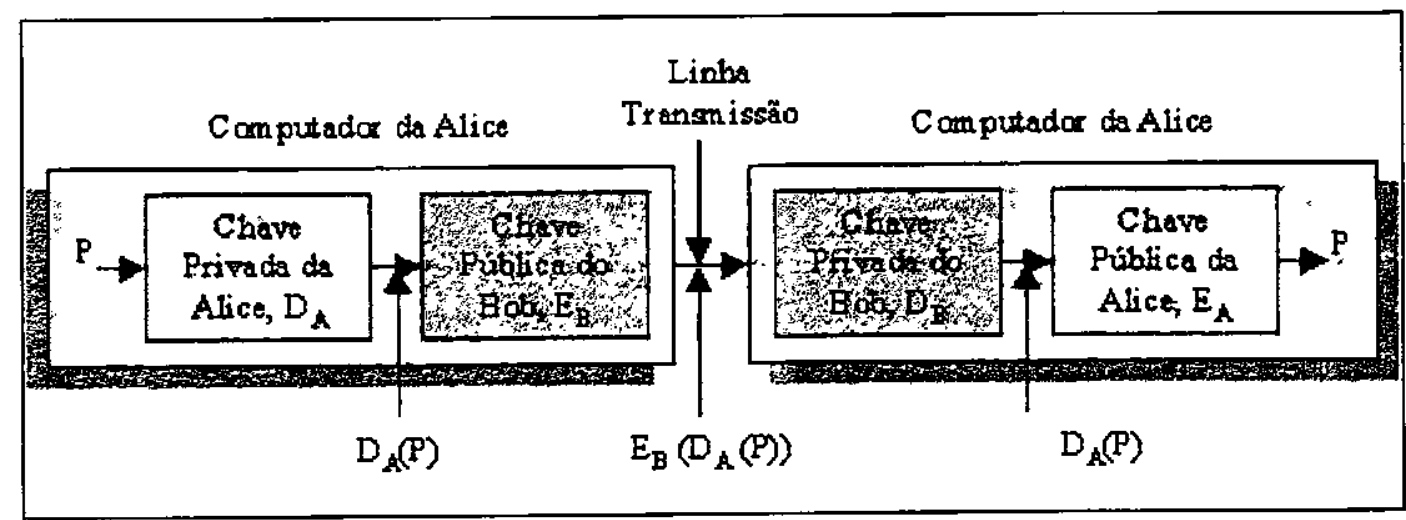

Fig. 4.9 - Assinatura Digital usando Criptografia de Chave Pública (Tanenbaun 1996)

Nota-se que somente Bob poderá abrir essa mensagem com sua chave privada a fim de obter $D_{A}$ $(P)$, após o que ele pode usar a chave pública de Alice para obter a mensagem original.

Nesse caso, se por ventura Alice quiser negar o envio da mensagem, Bob pode apresentar como prova a mensagem $P$ e também $D_{A}(P)$, que é facilmente verificado como sendo gerada pela chave privada de Alice bastando aplicar sua chave pública para decodificar. O resultado da decodificação de $D_{A}(P)$ com a chave pública de Alice será igual a $P$, e como somente Alice conhece sua própria chave privada, fica provado que foi ela quem enviou a mensagem. Essa forma de provar que Alice enviou a mensagem não funciona se mais alguém conhecer sua chave privada, ou ainda se Alice trocar sua chave, sem deixar qualquer registro sobre as chaves já utilizadas.

\subsubsection{Certificado Digital}

É um documento eletrônico usado para identificar uma pessoa, uma companhia ou outra entidade qualquer (Netscape 1997c). As Autoridades de Certificados (AC's) são entidades que validam 
identidades e emitem certificados que as garantam. Os métodos usados para validar uma identidade varia de acordo com a política de cada AC. O pedido de certificação é recebido, e então elas fazem uma investigação sobre a entidade requisitante para garantir que são verdadeiras e fazem o que se propõem a fazer. Se uma empresa apresenta um certificado de uma entidade emitente confiável, então ela se torna confiável. O processo, e a confiança depositada sobre essa empresa, em muito dependem da confiabilidade que é depositada na entidade emitente de certificados.

Um certificado prova a identidade do portador, assim como qualquer outra identificação pessoal. Ele inclui uma chave pública, o nome da entidade que ele identifica, uma data de expiração, o nome da $\mathrm{AC}$ que o emitiu um número de série e outras informações, além de, principalmente, a assinatura digital da AC emitente. Essa assinatura digital atribui ao certificado o valor de uma "carta de apresentação" para usuários que conheçam e confiem na $\mathrm{AC}$, mas não conhecem a entidade identificada pelo certificado.

\subsubsection{Tipos de Certificados}

O Netscape Communicator reconhece cinco tipos de certificados:

- Certificados de Cliente com SSL: usados para identificar clientes para servidores via SSL.

- Certificados de Servidores com SSL: usados para identificar servidores para clientes via SSL.

- Certificados S/MIME: usados para assinar e codificar email.

- Certificados de Assinatura de Objetos: usados para identificar assinantes de código Java, scripts de JovaScript, ou outros arquivos assinados.

- Certificados de AC: usados para identificar Acs.

Todo certificado inclui:

- Informação sobre a chave pública do usuário, incluindo o algoritmo usado e a representação da própria chave.

- número de série do certificado.

- periodo de validade do certificado

- Uma representação para o nome da entidade representada pelo certificado.

- Uma representação para o AC que emitiu o certificado 
- algoritmo usado pela AC para criar sua própria assinatura digital.

- A assinatura digital da AC, obtida através do "hashing" de todo dado no certificado e codificado com a chave privada da AC.

Pode conter ainda extensões não apresentadas aqui, a fim de prover dados adicionais usados pelo cliente ou pelo servidor. Na figura 4.10 é apresentado um acesso ao servidor usando certificado do cliente (Autenticação Forte).

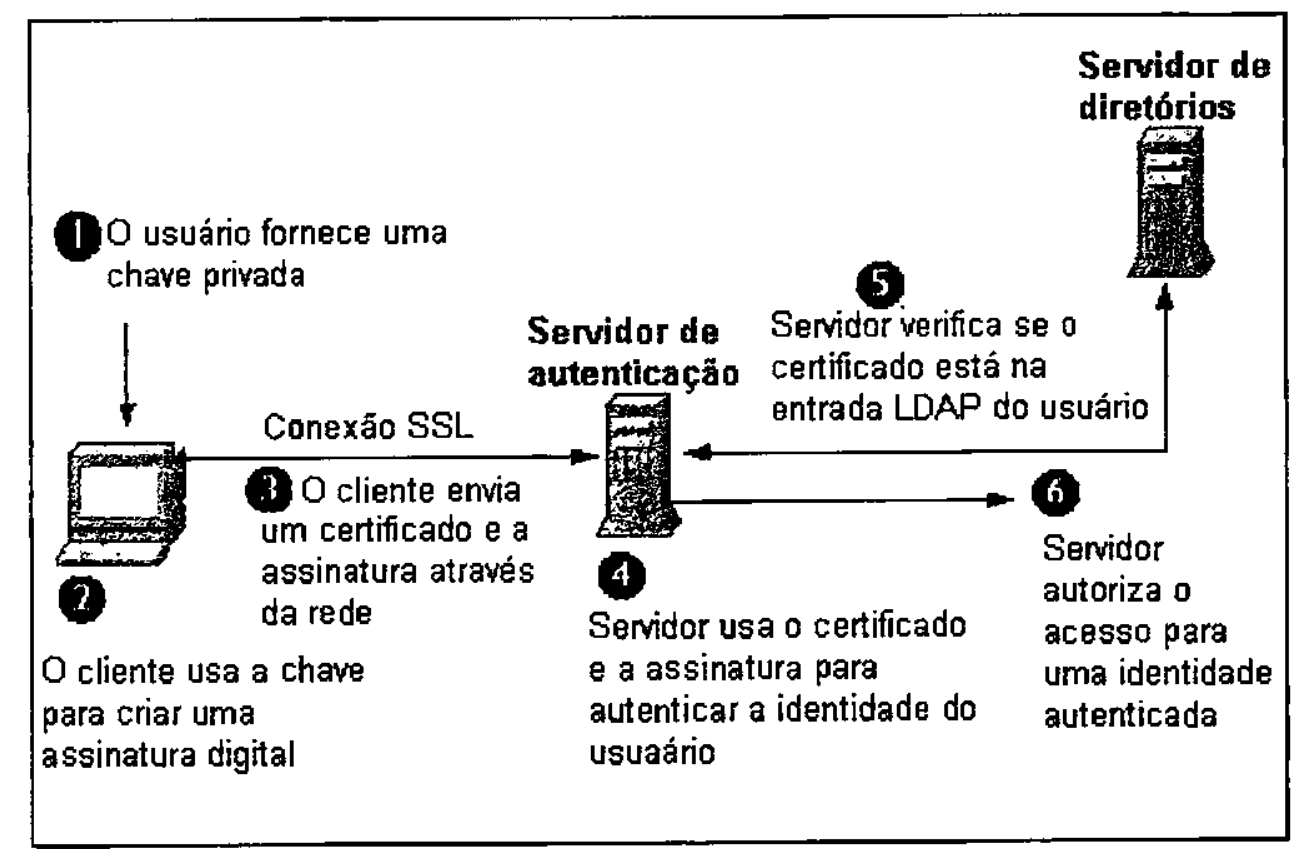

Fig. 4.10 - Autenticação Forte (Netscape 1997b)

Considerando que os protocolos de comunicação são grandes responsáveis por intrusões, alguns deles foram implementados já com medidas de proteção para as mensagens a serem transmitidas. Dentre eles estão:

\subsubsection{SSL}

(Secure Socket Layer) - (Netscape 1997a) A Netscape projetou e especificou um protocolo para prover camada de segurança de dados entre protocolos de aplicação (como HTTP, Telnet, NNTP, ou FTP) e o TCP/IP. Esse protocolo de segurança provê criptografia de dados, 
autenticação de servidor, integridade de mensagem, e autenticação de cliente opcional para uma conexão de TCP/IP.

Com ajuda de consultores independentes e muitos contribuintes externos, a Netscape desenvolveu o protocolo SSL para prover um alto nível de segurança à comunicações na Internet. Muitos vendedores de software na comunidade Internet já aceitaram o SSL como padrão, e também foi submetido à Internet Engineering Task Force (IETF) para validação como o padrão de Internet oficial para Segurança na Camada de Transporte (TLS). A Netscape trabalha com o IETF e outros consórcios de indústria e grupos de trabalho para assegurar que padrões de segurança abertos e interoperáveis existam agora e no futuro.

SSL é um protocolo não proprietário aberto. Foi submetido ao Consórcio W3 (W3C grupo de trabalho em segurança) por ser considerado um modo de segurança padrão para browsers da WWW (World Wide Web) e servidores na Internet. A Netscape está trabalhando com o W3C no sentido de desenvolver e padronizar mecanismos de segurança robustos e protocolos para a Internet.

\subsubsection{SHTTP}

( Secure HTTP )- Surgiu a fim de prover maior segurança aos dados que seguem o protocolo HTTP, adicionando à ele serviços de segurança utilizando-se do SSL. Esses serviços incluem Confidencialidade, Integridade, Autenticação de usuário e Certificação de servidores/serviços, que podem ser fornecidos de forma independente um dos outros. Requerimentos secundários incluem facilidade de integração e suporte de mecanismos para prover esses serviços.

O uso do HTTP para prover serviços especializados ou comerciais, e dados pessoais ou privados, necessita do desenvolvimento de versões seguras que incluam serviços de autenticação e privacidade. Tais serviços podem ser providenciados através de extensões do HTTP ou como um protocolo de segurança encapsulado.

A segurança na camada do SHTTP é independente dos serviços de segurança providos nas camadas de rede inferiores. Isso significa que o SHTTP pode coexistir em uma transação com 
tais mecanismos, cada um provendo serviços de segurança no nível apropriado, com, em algumas hipóteses, alguma redundância de serviço.

\subsubsection{Confidencialidade}

O SHTTP precisa prover confidencialidade às transações HTTP, via codificação das mensagens. A transação HTTP completa precisa ser considerada privada. Assim, os cabeçalhos e objetos de dados da requisição do cliente e da resposta do servidor precisam ser confidenciais.

\subsubsection{Autenticação de Serviços}

O SHTTP precisa suportar a autenticação do servidor HTTP para o cliente.

Para permitir privacidade ao usuário, o SHTTP deve suportar autenticação de serviço sem a autenticação do usuário.

Devido à identidade do objeto sendo requerido ser potencialmente sensível, autenticação de serviços deve acontecer antes de ser passado qualquer parte da requisição. Em casos onde o processo de autenticação dependa de algum dado de cabeçalho da requisição, o mínimo de informação necessária para a identificação da entidade a ser autenticada deve ser passado.

\subsubsection{Autenticação de Usuário}

O SHTTP deve suportar a autenticação do usuário para o servidor e a autenticação do cliente ao servidor HTTP, não importando os servidores "proxy" intermediários.

\subsubsection{Integridade}

O SHTTP deve prover garantia da integridade da transação HTTP, incluindo os cabeçalhos HTTP e os objetos de dados, tanto das requisições do cliente quanto das respostas do servidor.

\subsubsection{Integração}

A fim de suportar integração com versões atuais e futuras do HTTP, e de prover extensibilidade e independência de desenvolvimento, os serviços seguros providos pelo SHTTP precisam ser independentes de outros serviços providos pelo HTTP.

De acordo com o modelo de camadas dos protocolos de rede, o SHTTP deve ser:

- Independente do contexto ou da natureza dos objetos de dados sendo transportados 
- Ter implementação possível sobre uma variedade de esquemas de conexão e protocolos de transporte inferiores

\subsubsection{Mecanismos Múltiplos}

O SHTTP deve ser compativel com mecanismos múltiplos para autenticação e criptografia. Suporte para mecanismos múltiplos é requerido por razões como:

- Acomodação de variações em policiamento de sites, incluindo aquelas relacionadas a restriçōes externas na disponibilidade de tecnologias criptográficas.

- Suporte para uma variedade de aplicações.

- Suporte para implementações paralelas dentro de domínios administrativos e entre eles.

4.3.6. IPv6 - (ou IPNG - IP New Generation) (Hinden 1998; Tanenbaun 1996; Hinden 1995)

A IETF começou, èm 1990, a trabalhar uma nova versão do IP que "nunca" esgotaria seus endereços, resolvesse uma variedade de outros problemas e se tornasse mais flexivel, eficiente e seguro. Para encontrar um protocolo que satisfizesse os principais objetivos definidos, a IETF lançou um chamado por propostas e discussões no RFC 1550. Vinte e uma respostas foram recebidas. Em dezembro de 1992, sete propostas mais sérias estavam sob estudo. Três das melhores propostas foram publicadas na IEEE Network. Depois de muita discussão e revisão, uma versão combinada entre duas delas, e modificada, atualmente conhecida como SIPP (Simple Internet Protocol Plus) foi selecionada e lhe foi dada a designação de IPv6 (IPv5 já estava em uso para um protocolo de tempo real experimental) (Tanenbaun 1996; NWF 1998).

A Internet possui problemas de segurança e carece de mecanismos efetivos de privacidade e autenticação abaixo da camada de aplicação. O IPng supre essa deficiência tendo duas opções integradas que provêm serviços de segurança (Atkinson 1995a). Essas opçōes podem trabalhar separadamente ou unidas para prover diferentes niveis de segurança. $O$ primeiro mecanismo, chamado "Cabeçalho de Autenticação IPng", é um cabeçalho de extensão que provê autenticação e integridade (sem confidencialidade) a datagramas IPng (Atkinson 1995b). O segundo cabeçalho de extensão de segurança do IPng é o "Cabeçalho de Segurança de Encapsulamento 
IPng" (Atkinson 1995c). Esse mecanismo provê integridade e confidencialidade aos datagramas IPng.

Em geral IPv6 não é compatível com IPv4, mas é compativel com os outros protocolos da Internet, incluindo TCP, UDP, ICMP, IGMP, OSPF, BGP e DNS, algumas vezes com algumas pequenas modificações sendo necessárias (a maioria para a negociação com endereços maiores). Mais informação a respeito pode ser encontrada nos RFC 1883 ao RFC 1887.

\subsubsection{SET}

(Secure Eletronic Transactions) - (RSA 1998a) A Internet oferece grande oportunidade de anúncio de produtos online por todo o mundo. Entretanto as transações a serem efetuadas no sentido de consolidação de negócios pela Internet não têm apresentado o grau de segurança necessário. Para que transações de cartões de crédito e pagamento sejam confiáveis pela rede, elas precisam oferecer a mesma proteção contra fraude que as tradicionais transações face a face, ordem de pagamento ou ordem por telefone.

SET é um padrão de comunicação em redes desenvolvido pela RSA em conjunto com MasterCard, VISA International e um consórcio de outras empresas para transmissão de informações pessoais e financeiras sensiveis, como pagamento por cartões de crédito, através de redes públicas.

SET aceita o padrão de criptografia com chave pública e certificados digitais RSA. Usa criptografia e tecnologia relacionada para:

- Prover confiabilidade de informação sobre dados financeiros

- Garantir a integridade do pagamento

- Autenticar vendedores, bancos e consumidores durante a transação

Uma transação SET envolve quatro entidades principais definidas no protocolo SET:

- consumidor

- vendedor

- coletor ("acquirer")

- A autoridade em certificados 
As entidades comunicam entre si através de um protocolo de mensagens SET bem definido, e usam uma combinação de DES e Sistema de Criptografia de Chave Pública RSA para codificar a informação do cartão de pagamento.

A transação segue segundo os passos mostrados na figura 4.11:

1. consumidor faz o requerimento da compra ao vendedor

2. vendedor verifica com o coletor se o consumidor tem fundos

3. coletor autoriza a compra e verifica o certificado do vendedor

4. A ordem da compra é confirmada ao consumidor

5. vendedor faz o requerimento do pagamento ao coletor

6. coletor faz a transferência necessária do pagamento do banco do consumidor para o banco do vendedor.

A confidencialidade é atribuída à criptografia da informação de pagamento, que usa uma combinação de algoritmos de chave pública e de chave privada. Em geral, algoritmos de chave pública e secreta são usados juntos para codificar o conteúdo da mensagem com uma chave secreta pequena, que é distribuída de forma segura através de um par de chaves pública e privada. 


\section{O Processo de pagamento do SET}

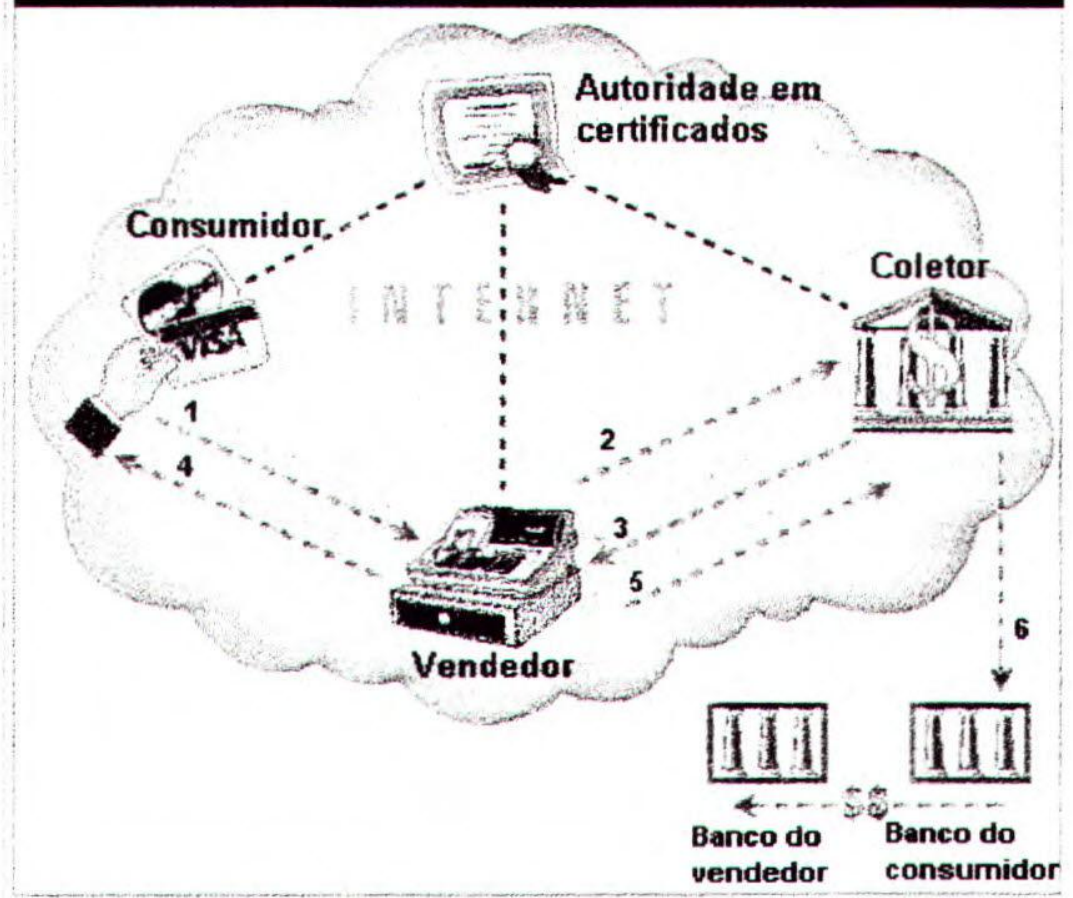

Fig. 4.11 - Processo de Pagamento do SET (RSA 1998a)

\subsubsection{Algoritmos no SET}

Em um primeiro passo as mensagens são codificadas com chaves DES de 56 bits, a serem transmitidas entre duas partes usando um "envelope" de chave pública RSA de 1024 bits. A chave DES de 56 bits é codificada com a chave pública do recebedor e adicionada à mensagem codificada (figura 4.12). O recebedor usa sua chave privada para decodificar a chave DES e poder usá-la para completar a decodificação do conteúdo principal da mensagem.

Essa abordagem usada pelo SET torna extremamente dificil o trabalho de um criptoanalista. Suponhamos então que um criminoso não pretenda decodificar a mensagem, e sim alterá-la mexendo nos bits codificados durante a transmissão. SET possui um mecanismo para verificar a integridade da mensagem, garantindo que a mensagem recebida é exatamente a mesma que foi enviada, sem qualquer tipo de alteração, e para prover autenticação da origem da mensagem. Isso é feito através de Assinaturas Digitais.

As assinaturas digitais no protocolo SET são realizadas através do uso combinado da criptografia RSA e outra técnica criptográfica conhecida como "Message Digests". Uma "digest" é criada quando uma função hash é usada para processar a mensagem, gerando um valor numérico único 
para aquela mensagem. Mudando um único bit na mensagem mudará aproximadamente metade dos bits na "message digest". A probabilidade de duas mensagens terem a mesma "digest" é de 1 em 1048. O uso de funções hash torna impraticável a recriação da mensagem a partir de sua "digest". Essas características virtualmente eliminam a possibilidade de modificar um par mensagem/"message digest" sem ser percebido.

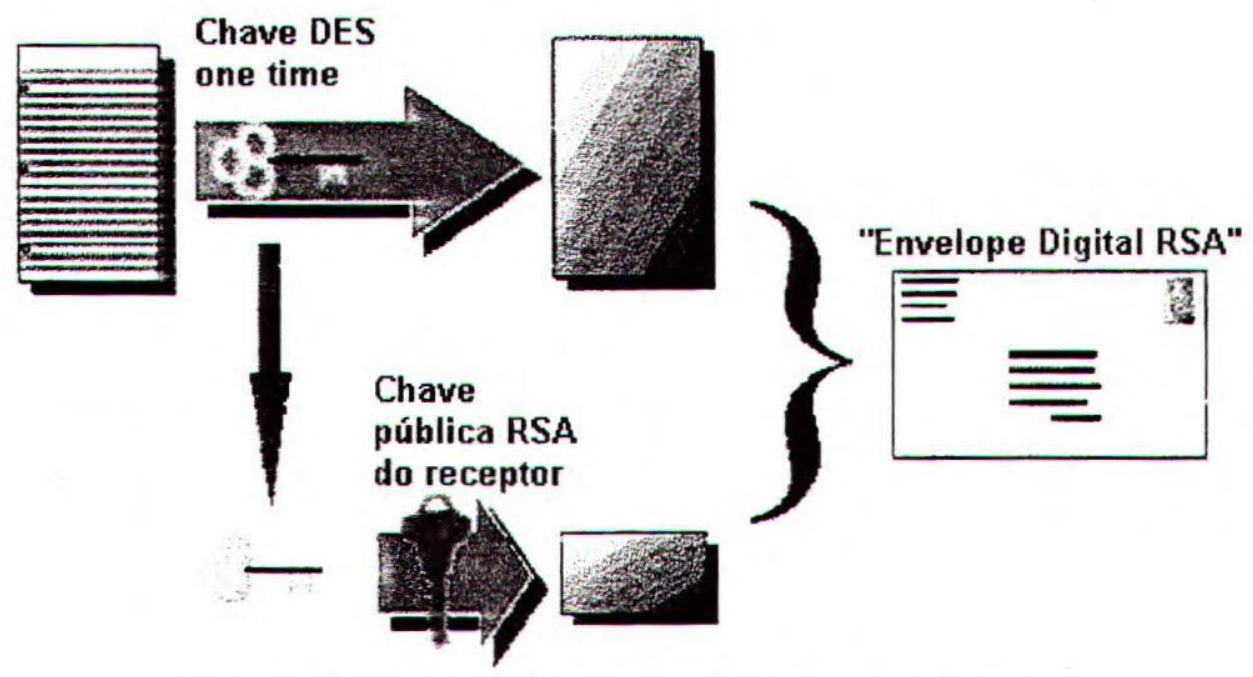

Fig. 4.12 - Criptografia de chave com DES e RSA (RSA 1997)

Quando combinadas com o Sistema de Criptografia de Chave Pública RSA no protocolo SET, as "message digests" podem ser usadas para assinar digitalmente uma mensagem de pagamento. Como pode ser visto na figura 4.13, uma "message digest" gerada pelo remetente é codificada com a chave privada dele. O recebedor da mensagem pode verificar a assinatura primeiro calculando sua própria "digest" da mensagem recebida, então decodificar a "digest" original com a chave pública do remetente e comparar as duas. Se forem iguais estão caracterizadas as autenticações do remetente e da mensagem simultaneamente. 


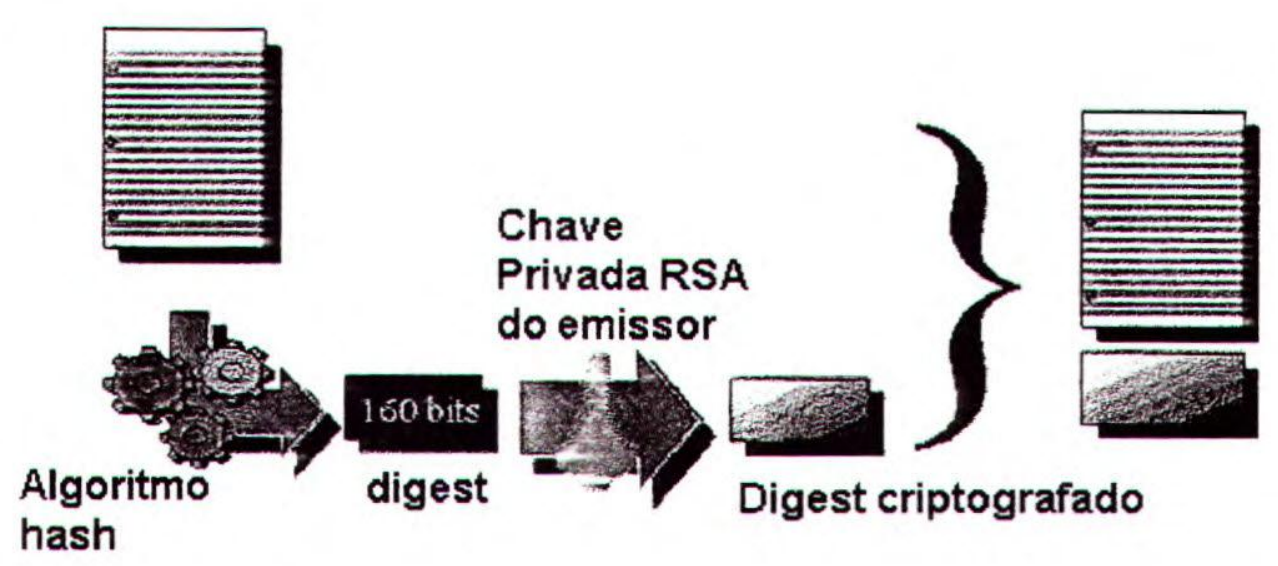

Fig. 4.13 - Autenticação com "Message Digest" (RSA 1997)

A autenticação das partes envolvidas em uma transação SET é fortificada através do uso de certificados. Uma Autoridade de Certificados confiável e segura distribui certificados assinados digitalmente para cada participante da transação, assegurando a autenticidade de suas chaves públicas. O consumidor pode se valer do uso das Autoridades de Certificados e do protocolo SET para se assegurar da identidade do vendedor com quem está tratando e não se preocupar quanto à segurança das informações de seu cartão de crédito.

A preocupação com a vulnerabilidade dos protocolos levou também à criação de uma política de gerência de sistemas com o objetivo de reduzir o risco de interceptação de dados importantes na rede (ex. senhas) diminuindo o tráfego desse tipo de informação pelas redes do sistema

\subsubsection{SSO}

Existe a preocupação com a necessidade, em vários sistemas, de um mesmo usuário possuir diversas senhas para diferentes servidores em diferentes áreas do sistema (XOC 1996a; Trickey 1997). Esse tipo de abordagem traz a preocupação relativa à segurança em cada vez que o usuário precise passar seu "username" e sua senha pela rede a fim de conseguir acesso a uma área diferente do sistema. A solução para esse problema é fazer com que o usuário, ao se "logar" uma vez com uma única senha (OPE 1998; XOC 1996b; Softools 1998) tenha acesso a todos os servidores aos quais ele é autorizado, sem necessidade de transmissão de senhas pela rede. Essa é a idéia do "Single Sign-On" (figura 4.14). 
O SSO provê uma única e segura autenticação do usuário (NIT 1998) e uma "capability" de identificação para aplicações variadas rodando sobre múltiplas plataformas, incluindo Windows NT, UNIX, Novell, e ambientes mainframe. O SSO eliminará a necessidade do usuário prover diferentes pares (nome, senha) para diferentes aplicações e plataformas. Resolverá também o problema de "overhead" de senhas na rede eliminando a necessidade de transmissões de senhas. A abordagem "Single Sign-On" da Netscape (Netscape 1997b) envolve o uso de certificados digitais para realizar a autenticação de usuários aos servidores. Para os produtos da Netscape se trata de um mecanismo de autenticação que substitui muitas autenticações do tipo múltipla-senha sem afetar mecanismos de controle de acesso existentes.

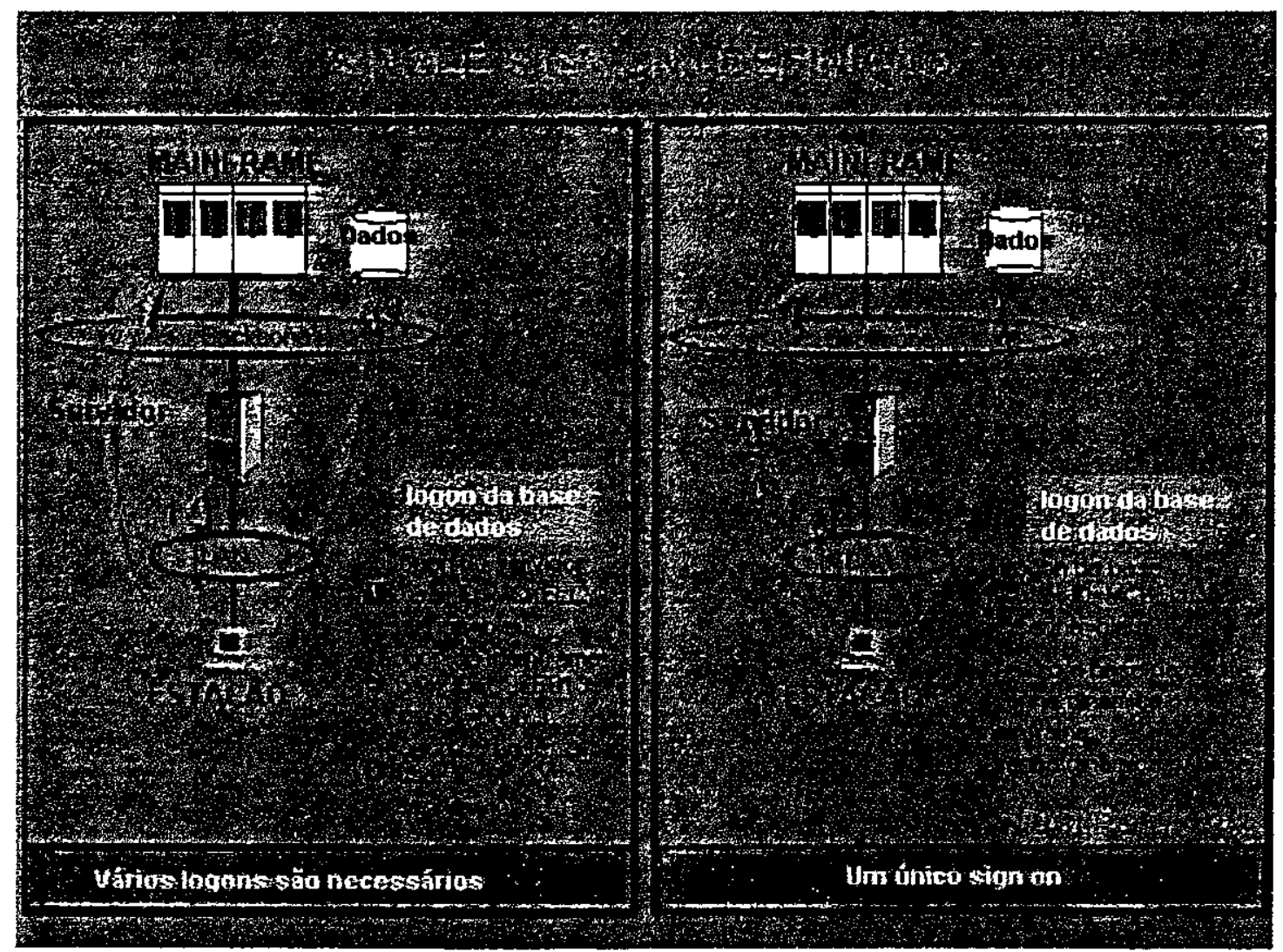

Fig. 4.14 - Modelo de autenticação (a) múltiplas senhas. (b) "Single Sign-On" (Softools 1998)

Ao se "logar" no servidor o usuário entra na Lista de Controle de Acesso (LCA) desse servidor. Se é importante a identificação do usuário o servidor solicita sua autenticação em forma de nome e senha ou de um certificado digital. Uma vez identificado o usuário seus acessos às partes do sistema são permitidos ou negados de acordo com seus privilégios, sem a necessidade de novas autenticações. 
A abordagem da Netscape para o SSO faz a autenticação baseada em certificados passados usando SSL, e não baseada em tráfego de senhas pela rede (figura 4.15). Essa abordagem permite:

- Facilidade de uso - O usuário "loga" uma vez e acessa tudo o que the é permitido, sem ser freqüentemente interrompido com pedidos de senhas.

- Gerenciamento Simplificado - O administrador pode controlar as permissões de acesso controlando a lista de autoridades de certificados. Essa é uma lista menor que a lista de nomes e senhas e não costuma mudar muito.

- Controle de Acesso Não Afetado - O SSO envolve mecanismos de autenticação de clientes, e não mecanismos de controle de acesso. Isso é, Não é necessário que o administrador mude a LCA originalmente construída para trabalhar com a autenticação por senhas.

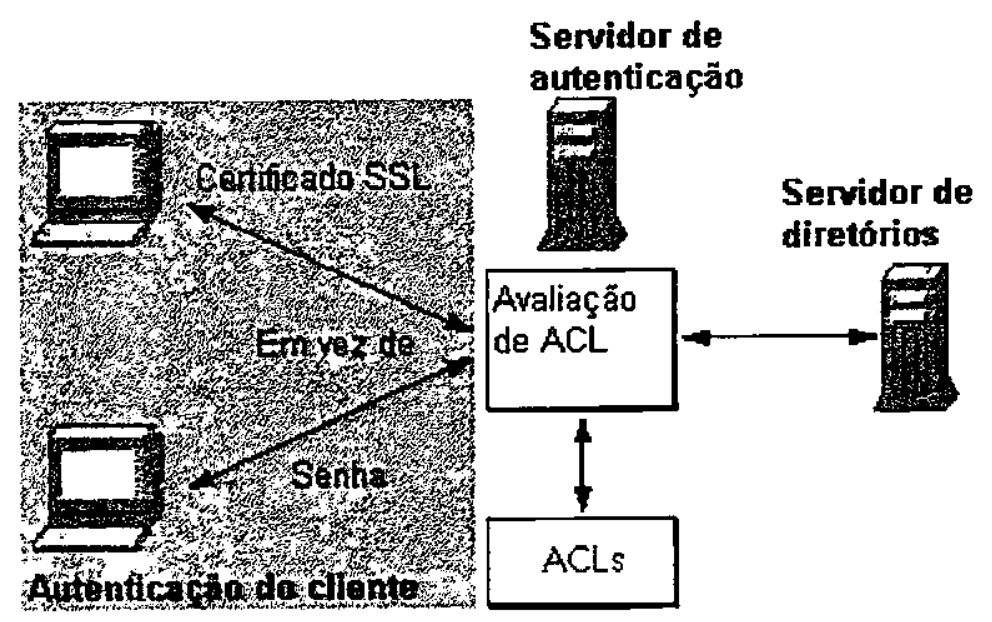

Fig. 4.15 - Abordagem SSO da Netscape (Netscape 1997b)

A autenticação de clientes baseada em nomes e senhas é conhecida como "Autenticação Básica", e a autenticação baseada no uso de certificados é algumas vezes chamada de "Autenticação Forte".

\subsubsection{A Autenticação de Clientes e o "Single Sign-On"}

Informação enviada de um computador a outro através de uma rede TCP/IP pode passar através de vários outros computadores pelo caminho, tornando possivel a perda ou a substituição da informação enviada. Além disso um usuário não tem qualquer garantia de que o site que ele está 
visitando na web é o que diz ser, e os administradores não sabem quem são os usuários que visitam seus sites.

Embora vários riscos de segurança não tenham tanta importância em usos casuais da Internet, eles são inaceitáveis em uma intranet ou extranet de uma empresa. Para evitá-los o administrador precisa obter a autenticação do usuário. Nomes e senhas são usados para autenticar sua identidade, confirmando se ele é mesmo quem diz ser.

SSL auxilia a autenticação provendo privacidade e integridade. Com esse protocolo é possivel o servidor se autenticar ao cliente e o cliente se autenticar ao servidor, estabelecendo assim uma conexão segura por criptografia entre as duas máquinas.

Uma conexão com um servidor autenticado com SSL toma extremamente dificil a perda ou modificação de dados enviados sem deteç̧ão, ou ainda dúvidas sobre a identidade do servidor. Entretanto, se o cliente também não for autenticado, qualquer usuário pode conectar e ter acesso aos recursos gerenciados pelo servidor.

A autenticação do cliente é essencial para a segurança da rede na maioria das "intranets" e "extranets". Para isso pode ser usada uma das duas formas de autenticação de clientes citadas: Autenticação básica (com nome e senha) ou autenticação forte (com certificados).

Tirando proveito dos itens citados acima (criptografia, assinatura digital, certificado digital, protocolos seguros), diferentes serviços de proteção foram desenvolvidos para serem incorporados aos sistemas. Dentre eles estão:

- firewalls

- sistema de detecção de intrusão

- proteção de arquivos (criptografia)

- proteção contra vírus

- proteção contra applets java e activeX

- monitoramento

- VPN

E podernos caracterizá-los da seguinte forma: 


\subsubsection{Firewalls}

Os firewalls funcionam como uma barreira na "porta" da rede, com o intuito de permitir apenas entradas e saidas autorizadas, controlando assim o acesso ao sistema. São usados para filtrar tráfego TCP-IP, tipicamente onde uma rede se conecta com outra, que pode ser confiável ou não, prevenindo e bloqueando ataques (Seifried, 1999). Dependendo do firewall usado pode-se conseguir caracteristicas como:

- Bloqueio/permissão de passagem de dados baseado em $\mathrm{P} /$ porta/interface origem/destino;

- Mascaramento (masquerading) de conexões, baseado em IP/porta/interface origem/destino;

- Port forwarding;

- Criação de cadeias, para regras e condições mais intrínsecas, mais fácil de manter;

- Qualidade de serviço (QOS - quality of service) em roteamento, útil em conexões de baixa velocidade, ou conexões saturadas;

- Especificação de $\mathrm{P} /$ porta/interface, bem como especificação inversa (usando o !).

- Log de conexס̃es;

- alertas;

- autenticação;

- NAT (Network Address Translation);

- NAT dinâmico;

- etc.

Ao escolher usar um firewall deve-se tomar algumas medidas para garantir sua eficiência, dentre as quais:

- Definir o firewall a ser usado de acordo com capacidades que atendam as necessidades;

- Preferencialmente usar uma máquina exclusivamente como firewall, não dando a ela nenhuma outra função;

- Estabelecer segurança fisica para a máquina, permitindo acesso apenas ao administrador da rede;

- Definir normas de uso de serviços disponiveis na rede, onde pode-se estabelecer os serviços permitidos controlados pelo firewall;

- Definir como realizar a instalação e configuração da máquina do firewall. 
A primeira decisão a tomar é o que fazer com a permissão default e com a negação default, seguido por quais serviços, servidores e hosts pretende-se dar permissão ou bloquear. Com essas determinações pode-se estabelecer as regras de funcionamento do firewall. Cada regra constitui uma diretriz de ação a ser efetuada quando um pacote tenta entrar ou sair da rede. Se as características do pacote o incluírem em uma classe permitida, esse poderá então ter sua passagem liberada, mas se o pacote pertencer a alguma classe não permitida, sua passagem será barrada.

Há duas formas diferentes de se estabelecerem as regras:

- O que não é permitido especificamente, é negado (negar tudo, aplicando exceções a serem permitidas);

- O que não é negado especificamente, é permitido (permitir tudo, aplicando exceções a serem negadas).

No primeiro caso as regras devem ser dispostas de forma que primeiramente apareçam as exceções com as permissões desejadas e ao final é colocada uma regra que nega toda e qualquer situação. Assim, ao chegar um pacote no firewall, suas características são verificadas a partir da primeira regra. Se existir uma regra que lhe garanta permissão, ela será cumprida e o pacote terá o caminho liberado. Se nenhuma lhe classificar como autorizado até chegar à última regra, essa será cumprida e o pacote terá passagem negada. $O$ segundo caso é análogo, colocando primeiro as exceções que negam a passagem e por fim a regra que dá permissão total. Se alguma regra explicitar a negação de um pacote, ele é então negado. Se o processo chegar até a última regra o pacote tem sua passagem automaticamente liberada.

\subsubsection{Sistemas de detecção de intrusão}

Os Sistemas de Deteç̧ão de Intrusão (SDI's) têm como objetivo detectar as invasões ocorrentes em uma rede. Muitas vezes esse tipo de intrusão apresenta determinados comportamentos característicos. Há muitos invasores que usam a mesma linha de ação para penetrar em um sistema sem autorização. $O$ que o sistema de deteç̧ão de intrusão faz é observar e analisar as ações realizadas no sistema e, no caso de identificar características de uma intrusão, alertar o 
sistema e/ou seu gerente, que deve tomar as providências necessárias a uma boa proteção contra a invasão, e talvez até contra-atacar.

\subsubsection{Proteção de arquivos (criptografia)}

Os arquivos podem ser alcançados através da rede, uma vez que a máquina que os guarda esteja conectada. Uma forma de proteger as informações contidas nesses arquivos, e inibir o ataque aos mesmos, é codificar essas informações. A criptografia é antiga, e ao longo de sua existência tem se desenvolvido bastante. Existem diferentes tipos de criptografia, podendo ser melhores ou piores conforme a situação.

Apesar de poder ser considerado eficiente, não é uma abordagem muito utilizada por se tornar bastante "pesada" no que diz respeito a armazenar e recuperar os arquivos. Isso porque a criptografia segura não é um processo muito rápido, e como os arquivos são armazenados e recuperados freqüentemente, afetaria de forma considerável o desempenho do sistema.

\subsubsection{Proteção contra applets Java e ActiveX nocivos}

Da mesma forma que os vírus podem prejudicar o sistema, applets Java e ActiveX podem atrapalhar bastante caso tenham sido desenvolvidos para isso, bastando o acesso às páginas que os contém. Eles podem prejudicar o browser, roubar informações e enviá-las através da rede, ou ainda executar ações danosas ao sistema. Os applets Java e ActiveX são programas desenvolvidos e disponibilizados em diversos sites e são executados na máquina que os visita. Portanto, assim como dẹve-se tomar cuidado como vírus em acessos a sites, também o deve tomar com relação a esses programas.

\subsubsection{Proteção contra vírus}

Outra grande preocupação dos gerentes de sistemas são os víns de computador que se proliferam através da rede. Com acessos freqüentes a sites não confiáveis e downloads desses sites, muitas vezes podem ser trazidos ao sistema arquivos infectados, de propósito ou não, que 
acabam por infectar todo o sistema. Por isso é muito importante ter cuidado por onde "navegar" e o que trazer ao sistema.

Existem aplicativos desenvolvidos com a tarefa de detectar e evitar a entrada de vírus no sistema, seja ela através de mails ou de downloads.

\subsubsection{Monitoramento}

Várias ações hostis podem ser realizadas em um sistema, consciente ou inconscientemente, ou seja, algum usuário pode estar propositadamente tentando atacar o sistema, ou pode simplesmente ter efetuado alguma operação de forma errada causando assim tal ação. A função do monitoramento é verificar as operações realizadas no sistema e estar atento para ações hostis que podem surgir a partir dessas operações. Para o serviço de monitoramento não importa se o usuário que originou a ação hostil teve ou não esse propósito. Sua função é detectar tais ações e comunicar ao funcionário, ou ao subsistema, encarregado para que as devidas providências sejam tomadas em prol da segurança do sistema.

O serviço de monitoramento pode trabalhar de duas formas:

$>$ Detectando a ação hostil depois de iniciada

$>$ Antevendo a ação hostil

No primeiro caso a ação somente é percebida depois de já ter sido iniciada. A partir daí deve ser notificado ao responsável de forma que esse (seja ele um funcionário ou um subsistema) possa agir contra tal ação, proteger o sistema e reparar eventuais danos causados.

Existem e são conhecidos diversos padrões de comportamento de ataque que levam a uma ação hostil ao sistema. No segundo caso o serviço de monitoramento observa as operações dos usuários e as avalia em virtude dos padrões conhecidos. Se essas operações seguem algum tipo de padrão que o serviço julgue apresentar alta probabilidade de caracterizar um ataque, a notificação ao responsável pode ser feita antes que a ação hostil seja iniciada, permitindo assim que esse tome suas providências de modo que o sistema não sofra tal ataque. Esse serviço apresenta semelhanças ao serviço de detecção de intrusão. 


\subsubsection{VPN}

A tecnologia VPN (Virtual Private Network) vem em auxílio às redes de computadores distribuidas fisicamente em diferentes localidades. Uma VPN é basicamente uma rede privada segura funcionando sobre uma infra-estrutura de rede vulnerável como a Internet. Dessa forma pode-se estabelecer contato confiável com escritórios regionais, funcionários móveis, parceiros de negócios, fornecedores ou clientes (King, Christopher M. 1999; Check Point 1998a; Check Point 1998b). Algumas vezes um canal VPN é chamado de túnel seguro de comunicação, dentro do qual passam informações que ninguém, externo à comunicação, consegue compreender.

As conexões em uma VPN podem ser feitas entre sites de empresas (site a site) ou entre um usuário e um site (acesso remoto). Entretanto há obstáculos a serem superados, tais como instalação na rede, provisão de software para o usuário remoto, tolerância a falhas e infraestrutura de chaves públicas. Esses obstáculos devem ser estudados juntamente com a decisão da implantação de uma VPN. Ainda assim as vantagens são grandes, telacionadas com a segurança conseguida e com o baixo custo, principalmente se comparada com o uso de linhas dedicadas usadas pelas empresas para conseguirem comunicação segura ou chamadas telefônicas de longa distância. Isso acontece porque ao decidir usar uma VPN o custo da ligação passa a ser o de uma ligação local até o provedor Internet, que em geral se situa na mesma cidade do usuário. A partir do acesso à Internet a VPN entra em ação para assegurar a privacidade das transmissões e recepções de informações. $O$ custo expressivamente menor do uso da estrutura que compõe a Internet para realizar as transferências de informações é um fator que leva muitas empresas a considerarem a VPN e optarem por adotá-la. As razões mais comuns que levam uma companhia a usar uma VPN são (King, Christopher M. 1999):

1. Baixar custo de telecomunicação usando a Internet ao invés de chamadas telefônicas de longa distância;

2. Baixar custo de telecomunicação reduzindo o número de linhas de acesso ao site da empresa; e

3. Baixar custos operacionais delegando o gerenciamento dos equipamentos de acesso remoto a um provedor de serviços. 
Segundo uma análise da Forrester Research Inc, ao comparar o custo de um Servidor de Acesso Remoto (SAR) tradicional com uma VPN nos Estados Unidos, as diferenças para cada 1000 usuários, que seguem a tabela 1 (Check Point 1998a), são:

\begin{tabular}{|c|c|c|}
\hline 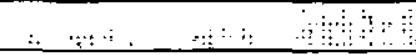 & SAR:Tradicional & $\because \quad \therefore \quad \ldots$ \\
\hline Telefone/Tarifas ISP* & $\$ 1.08 \mathrm{M}$ & $\$ 0.54 \mathrm{M}$ \\
\hline Suporte a usuário & $\$ 0.30 \mathrm{M}$ & $\begin{array}{c}\text { \$0.00M (incluído em custos } \\
\text { de acesso do usuário) }\end{array}$ \\
\hline Gastos Básicos & $\$ 0.10 \mathrm{M}$ & $\$ 0.02 \mathrm{M}$ \\
\hline Linhas T1 & $\$ 0.02 \mathrm{M}$ & $\$ 0.03 \mathrm{M}$ \\
\hline Total & \$1.50M & \$0.59M \\
\hline
\end{tabular}

Tabela 4.1. Comparação de gastos entre SAR e VPN

${ }^{*}$ ISP - Internet Service Provider

As VPN's funcionam entre as camadas de transporte e enlace do modelo ISO (figura 4.16) e são completamente transparentes à todas as aplicações de usuários. Softwares de segurança que rodam sobre a camada de transporte são considerados segurança de canal (ex. SSL ou Socks), e não são transparentes às aplicações de plataformas (King, Christopher M. 1999).

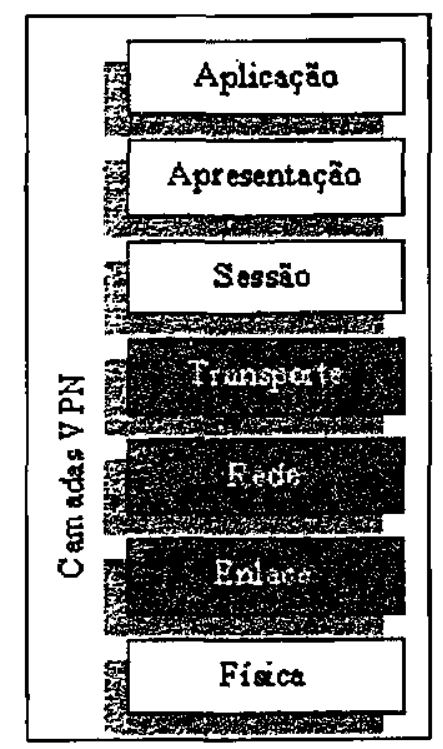

Figura 4.16. O lugar da VPN no modelo ISO

A implementação de uma VPN pode ocorrer de três formas (King, Christopher M. 1999): 
- Através de um dispositivo de propósito especial constituído de duas ou mais interfaces de rede, um sistema operacional de tempo real e um suporte à criptografia baseado em hardware.

- Uma solução completamente baseada em software que roda sobre a camada de transporte.

- Uma solução híbrida onde uma aplicação VPN roda em uma plataforma de computador padrão que utiliza um processador especial para criptografia que realiza as funções da VPN.

As entradas e saídas dos dados de uma VPN se dão através de um gateway VPN (dispositivo de rede responsável em prover serviços de criptografia e autenticação às máquinas - ou hosts servidos e protegidos por ele). A conexão VPN é transparente aos usuários. A interface do lado público (não confiável) do gateway é tipicamente chamada de "lado negro" (black side) e a interface voltada à rede interna (confiável) é chamada de "lado vermelho" (red side). No gateway os pacotes são tratados (pacotes de saída são codificados e enviados, e os de entrada bloqueados ou decodificados e transmitidos para a máquina destino dentro da rede interna). Pacotes não codificados não devem ser permitidos no lado negro de um gateway VPN e pacotes codificados da rede externa não devem ser permitidos no lado vermelho.

Quando falamos de um cliente VPN nos referimos a um dispositivo de rede individual, como um PC em casa, no qual altera-se o software de transporte na rede para permitir codificação e autenticação entre gateways VPN e/ou outros clientes VPN. Para que uma VPN possa ser bem sucedida é necessário que ela possa lidar com os seguintes componentes (Check Point 1998b):

- Segurança: para se manter a segurança de uma VPN são necessários controle de acesso, criptografia e autenticação. $O$ controle de acesso protege as conexões de rede, permitindo somente usuários autorizados e limitando seus acessos a apenas aqueles recursos a eles estabelecidos. A criptografia protege a privacidade de dados contra intrusos. E a autenticação funciona de forma a verificar as identidades dos usuários e a integridade de dados recebidos.

- Controle de Tráfego: tem como objetivo garantir confiabilidade, qualidade de serviço e performance de alta velocidade. Considerando-se que a comunicação pela Internet pode se congestionar, aplicações críticas de negócios podem se tornar inviáveis se não tiverem suas mensagens despachadas de modo confiável. Para isso o tráfego pode se tornar prioridade. 
- Gerenciamento de Empresa: garante uma boa integração da VPN com a política de segurança global da empresa. Dessa forma pode-se obter um gerenciamento centralizado, de forma local ou remota, da segurança e escalabilidade da solução adotada.

\subsubsection{Segurança em VPN's}

A segurança em uma VPN não se constitui apenas de autenticação e criptografia (Check Point 1998a), que garantem a privacidade durante as transferências de dados. Para se manter a segurança de uma VPN é necessário também o controle de acesso.

Controle de Acesso determina quanta liberdade um usuário VPN tem, controlando o acesso de parceiros, empregados e outros usuários externos a aplicações e diferentes partes da rede. Uma VPN sem o controle de acesso protege apenas as transmissões de dados, deixando a empresa vulnerável a invasões em seus sistemas.

Autenticação em VPN's é dividida em dois tipos: autenticação de usuários e autenticação de dados. A autenticação de usuários trata da verificação e confirmação da identidade do usuário, ou seja, certificar-se de que um usuário é realmente quem afirma ser. A autenticação de dados tem como objetivo verificar se a mensagem recebida é exatamente igual àquela que foi enviada pelo usuário com quem está se tratando. $O$ ideal é ter a possibilidade de realizar os dois tipos.

Criptografia é usada para proteger mensagens enviadas por usuários devidamente autenticados através da rede. As chaves da criptografia servem para a codificação e autenticação dos dados, e após serem escolhidas (definidas e implementadas) devem ser protegidas através de um sistema de gerenciamento de chaves.

\subsubsection{Controle de Tráfego}

Sendo a VPN uma extensão da rede da empresa é natural que ela aumente o tráfego da rede, arriscando assim afetar sua performance. É importante que a VPN escolhida e implementada na rede tenha o menor impacto possível no modo como os usuários acessam os recursos da rede.

\subsubsection{Gerenciamento de Empresa}

É importante que a VPN faça parte da estrutura da empresa sendo controlada juntamente com o resto dos seus elementos de segurança, não precisando assim de uma política de segurança separada, o que complicaria o trabalho de seu gerenciamento e o gerenciamento do resto da segurança. 
Podemos agrupar as configurações de VPN's em três categorias primárias (Check Point 1998a; King, Christopher M. 1999):

- VPN Intranet: provê comunicações seguras entre os departamentos de uma empresa e seus escritórios separados fisicamente (figura 4.17). Requer codificação (criptografia) forte e rápida, confiabilidade e fácil administração. A velocidade da codificação é requerida no sentido de acomodar-se aos links de alta velocidade das LAN's. A confiabilidade é necessária para garantir prioridades a aplicações criticas como sistemas financeiros, gerenciamento de bases de dados de vendedores e clientes, e troca de documentos. E sua administração deve lidar facilmente com mudanças como inclusão de novos usuários, novos escritórios e novos aplicativos.

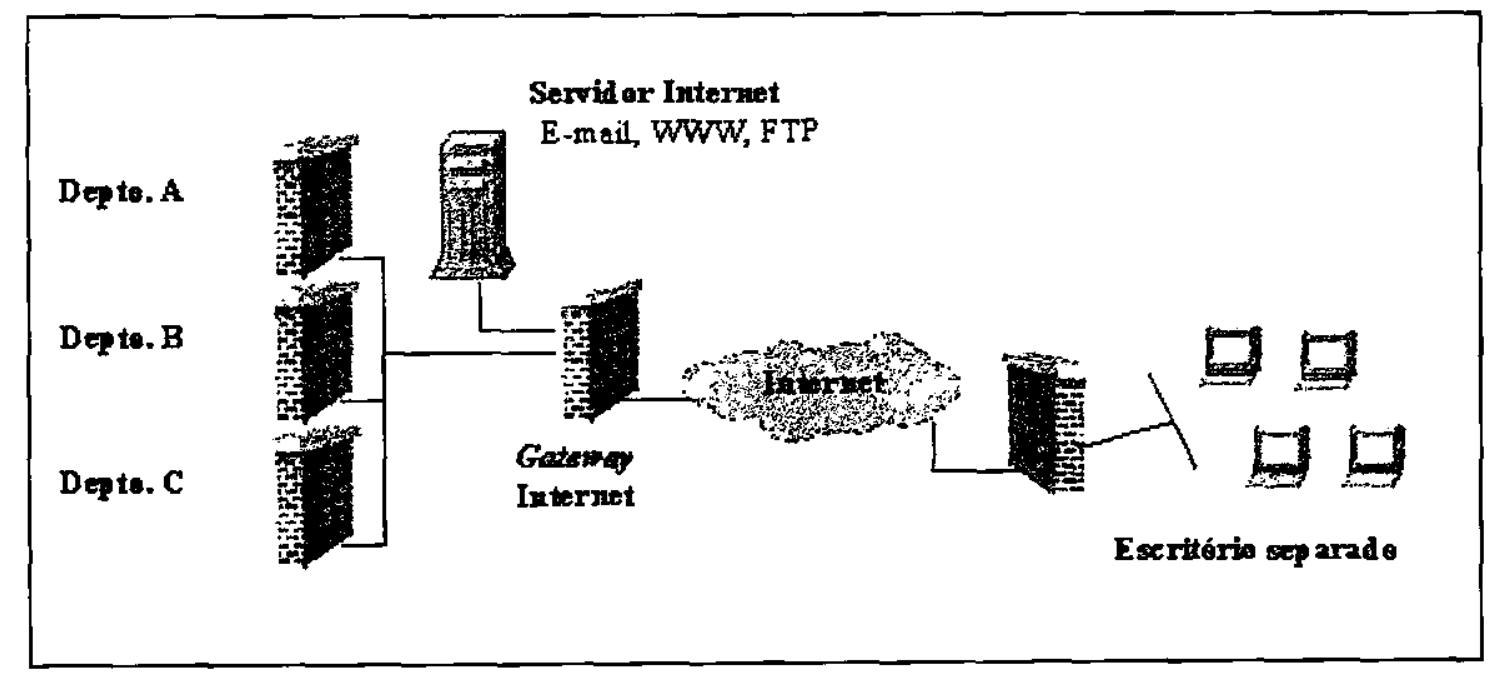

Figura 4.17. VPN Intranet

- VPN Acesso Remoto: implementa uma VPN entre a empresa e seus empregados móveis (figura 4.18). Requer confiabilidade, qualidade de serviço, autenticação forte, gerenciamento centralizado e alto grau de escalabilidade. A confiabilidade e a qualidade de serviço se fazem necessárias devido aos acessos serem tipicamente limitados à baixa velocidade dos modems. A autenticação forte é importante para que se possa verificar a identidade do usuário remoto. E o gerenciamento centralizado e a escalabilidade devem lidar com os links da VPN e o grande número de usuários que a acessam. Requer também que o software de cliente VPN seja instalado na máquina do usuário. 


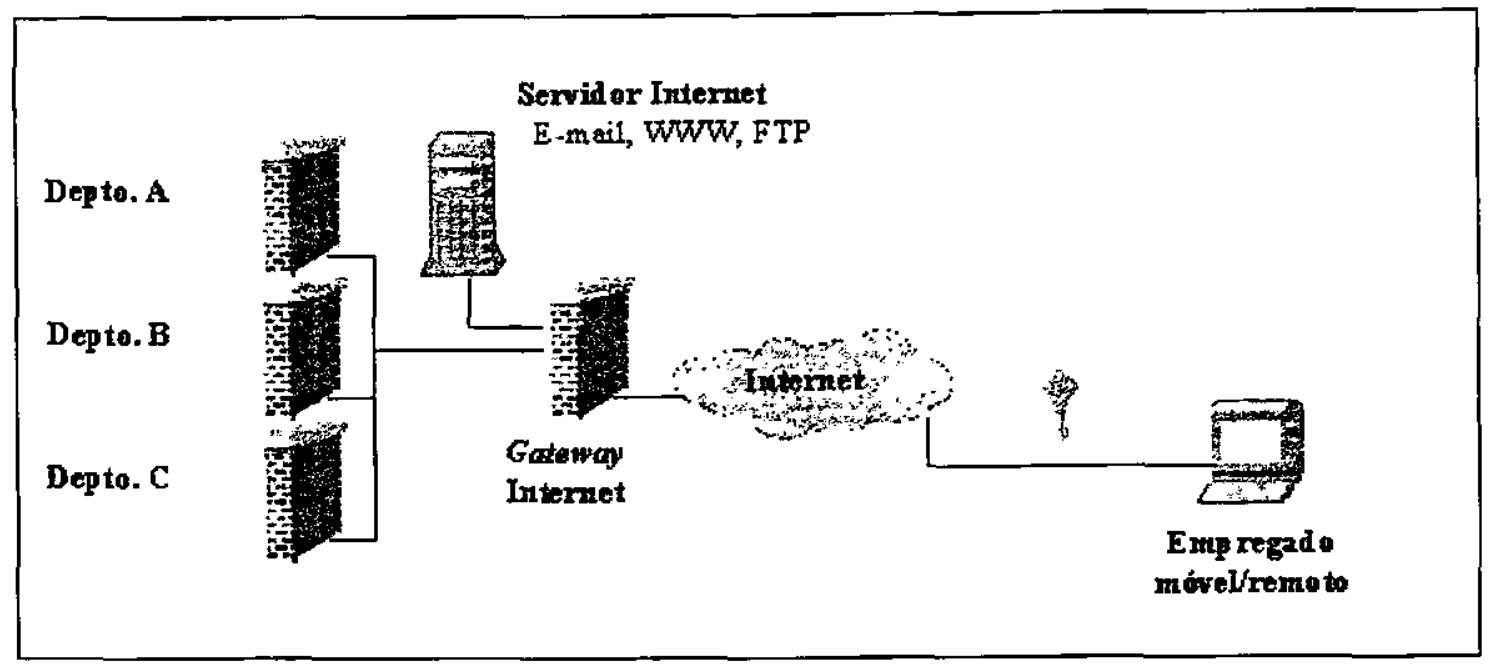

Figura 4.18. VPN Acesso Remoto

- VPN Extranet: é uma forma de se estabelecer a comunicação, de modo seguro, com parceiros estratégicos, clientes e fornecedores (figura 4.19). Requer uma solução aberta e baseada em padrões e controle de tráfego. Os padrões adotados e a abertura da solução implementada se dão para garantir a interoperabilidade com os diferentes tipos de soluções que cada parceiro implementa em sua própria empresa. $O$ controle de tráfego é importante para eliminar gargalos nos pontos de acesso à rede e garantir despacho e resposta rápidos para dados críticos. Há dois tipos de VPN's extranet: "um-para-muitos" e "muitos-paramuitos". Uma extranet um-para-muitos ligando muitas empresas a um recurso é mais comum atualmente (e. g., home banking). Devido às grandes diferenças entre diversas intranets entre as empresas, e às dificuldades que sua união apresenta, atualmente extranets muitos-paramuitos são menos comuns.

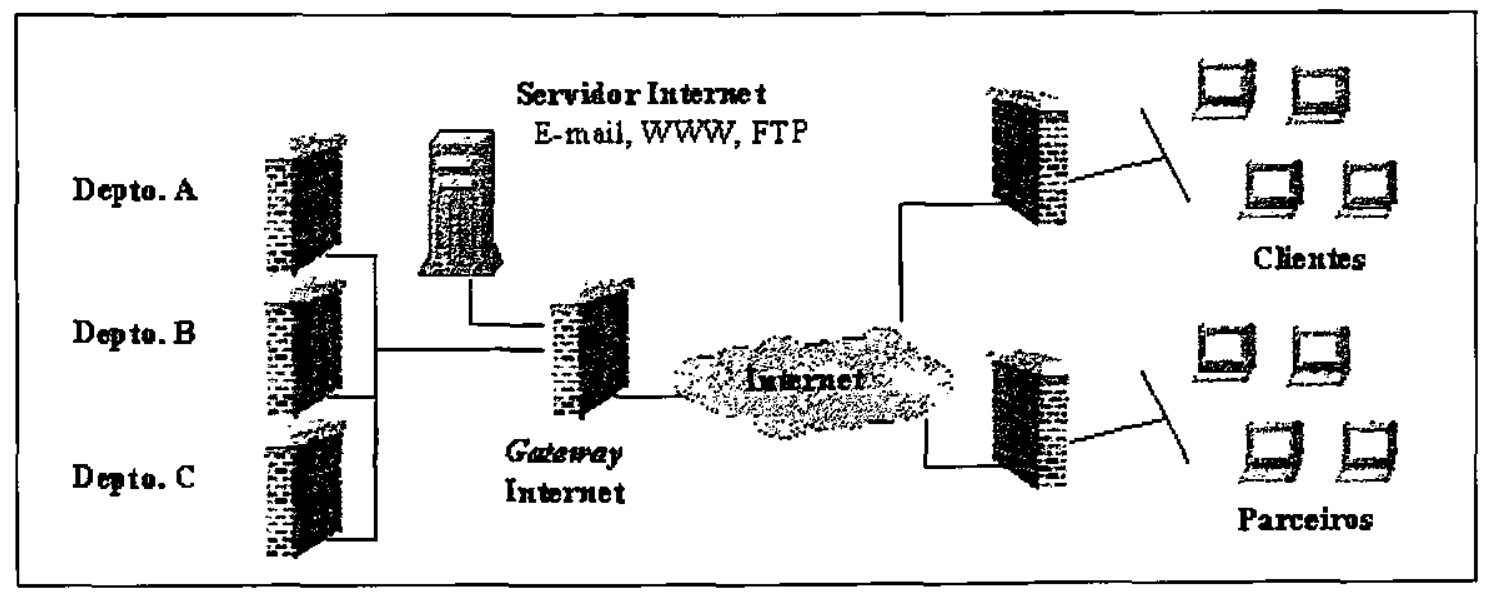

Figura 4.19. VPN Extranet 
O ideal é que uma empresa que decida adotar uma VPN como solução para seus negócios possa englobar esses três tipos, conseguindo com isso realizar seguramente, e a baixo custo, a conexão entre seus escritórios, o acesso de seus funcionários móveis e a aproximação com seus clientes e parceiros (figura 4.20).

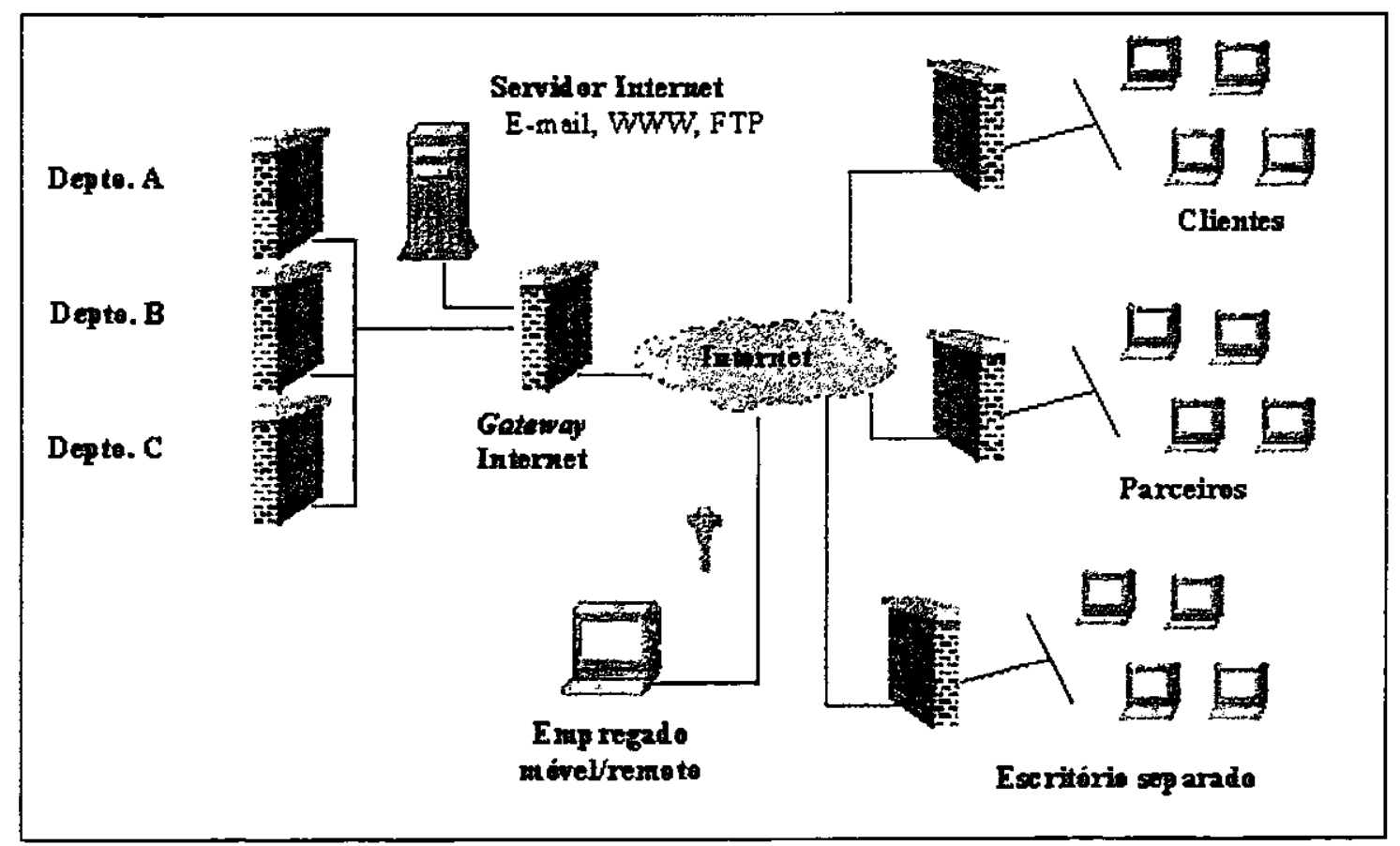

Figura 4.20. Implementaçāo englobando os três tipos de VPN: Intranet, Acesso Remoto e Extranet

Alguns obstáculos surgem com a decisão da adoção de uma VPN e aqui vamos citar alguns deles (King, Christopher M. 1999):

- Autenticação/Gerenciamento de chaves

Antes da negociação em si através da VPN as partes envolvidas têm de estabelecer a forma de segurança de dados que satisfaça a ambos, e para que isso seja possível suas identidades devem ser verificadas através da autenticação, que pode ser realizada de diferentes formas, de acordo com cada produto VPN disponivel. Dentre as alternativas de autenticação estão senhas compartilhadas e certificados digitais, suportadas pelos dispositivos VPN com conformidade ao 
padrão IPSec. De acordo com (King, Christopher M. 1999) autenticação baseada em certificados digitais são mais seguras, pois reduz a complexidade da distribuição de chaves.

\section{- Tolerância a falhas}

Disponibilidade dos recursos é de grande importância em uma empresa. Deve-se manter os serviços funcionando de forma contínua evitando que representem problema à transação em execução quando requisitados. Há diferentes maneiras de tratar a questão como com redundância de hardware, redundância de componentes, balanceamento dinâmico, etc. $\mathrm{O}$ objetivo é conseguir prover uma sessão ativa de modo que a VPN não sinta uma eventual falha do outro lado do túnel. É importante que isso exista entre todos os dispositivos VPN (gateways e clientes). No caso de um cliente detectar que um gateway não está respondendo a uma conexão ponto-a-ponto requisitada um gateway secundário deve poder ser definido.

\section{- Performance}

Um fator significante para a performance de uma VPN é a criptografia dos dados. O processamento requerido para uma boa criptografia pode se mostrar computacionalmente pesado. Se esse fator não for bem tratado a adoção da VPN pode comprometer toda a eficiência da rede de uma empresa. Uma alternativa a ser adotada é definir um servidor forte em processamento como responsável único pela criptografia e envio dos dados. Com essa abordagem os dados são enviados sem serem codificados para o servidor de criptografia, não sobrecarregando assim a máquina de origem da mensagem. O servidor então codifica os dados e os enviam para seu destino fora da empresa. Outro fator, que combinado a esse, se torna responsável por alterações na performance da VPN é a ocorrência de conexões simultâneas. Isso dificulta o trabalho de controle da segurança dos dispositivos de rede, pois uma boa VPN deve controlar também os acessos à rede da empresa.

- Transporte confiável

Apesar das VPN's serem independentes da subcamada de transporte de rede, caso haja um gargalo em algum ponto da rede entre os nós da VPN sua comunicação será afetada. A 
bancwidth de passagem das mensagens é importante no desempenho da VPN, e a Internet muitas vezes não consegue prover uma bandwidth adequada.

- Localização na rede

A localização da VPN na rede pode variar, no entanto deve seguir as seguintes regras:

- Não comprometer a política de segurança geral da rede;

- O gateway VPN não deve estar localizado em um ponto de falha único;

- O gateway VPN somente deve aceitar tráfego codificado pelo lado negro (não confiável) da rede;

- O gateway VPN deve aceitar tráfego codificado e não codificado no lado vermelho (confiável) da rede;

- O gateway VPN deve se defender de ameaças que possam vir da Internet;

- A arquitetura global do sistema deve filtrar o tráfego após a decodificação da VPN.

Algumas opções quanto à localização do gateway VPN são:

- Na frente de um firewall: com uma única conexão para a rede externa forma um ponto de falha único. Nesse caso o gateway VPN teria que aceitar dados codificados e não codificados, uma vez que é o único ponto ligado à rede externa.

- Atrás de um firewall: a segurança seria feita pelo firewall que teria que deixar passar alguns tipos de pacotes como cabeçalhos de autenticação para que pudesse chegar até o gateway VPN. Assim como no item anterior forma um ponto de falha único.

- Em um firewall: é uma boa idéia, consolidando a administração e gerenciamento dos componentes de rede. Entretanto atualmente não é uma solução viável devido às limitações quanto a habilidade de roteamento, performance em criptografia com chaves públicas e coordenação entre sessões codificadas durante execução de controle de acesso e logging.

- Paralelo a um firewall: de forma que haja duas conexões com a rede externa, uma para o firewall e uma para o gateway VPN, onde o segundo aceita apenas tráfego codificado. Nesta configuração o dispositivo VPN deve se defender contra ameaças externas, o que segundo King é perigoso, já que esses dispositivos não têm se mostrado muito robustos quando conectados diretamente à Internet. 
- Ao lado de um firewall: (em uma interface de firewall dedicada) dessa forma o dispositivo VPN é protegido contra as ameaças provenientes da Internet durante a filtragem do tráfego não codificado, enquanto o outro lado da interface do gateway VPN deve ser configurado para aceitar somente pacotes codificados. Todos os pacotes que entram pela interface interna devem ser codificados para serem enviados à Internet.

\section{- Endereçamento/Roteamento}

Antes de unir duas ou mais redes deve-se prestar atenção ao endereçamento delas. Se acontecer uma sobreposição de seus espaços de endereços particulares o trabalho de roteamento se torna um grande desafio. Um cliente VPN deve estabelecer uma conexão TCP/IP com a empresa através de um provedor Internet, formando então um túnel seguro de comunicação com o gateway da empresa. Após o túnel ser estabelecido com a empresa é importante que o cliente não permita tráfego fora do túnel, principalmente de forma não codificada, o que caracterizaria um "split tunneling" (túnel com brecha). O problema com esse tipo de situação é que um cracker que tenha comprometido a máquina do cliente possa usar essa "brecha" para lançar um ataque à intranet da empresa.

- Administração/Gerenciamento

Alguns produtos VPN, no intuito de controlar sua administração, dão suporte a diferentes niveis de privilégios dentro da VPN (ex. privilégios como "somente leitura" ou "escrita" a determinados grupos de dispositivos ou administradores). O gerenciamento da VPN deve ser realizado através de um canal seguro, o que não impede que o administrador esteja do lado negro da rede, usando um software cliente VPN. Uma questão importante é a provisão do cliente VPN, que pode ser feita de três formas básicas de distribuição: 1) envio de um disco pré-configurado ao usuário final, 2) realização de um download de um cliente genérico, ou 3) submissão de um formulário Web. Em qualquer abordagem tomada a meta é manter a configuração necessária como mínima possivel, deixando o máximo de informação de configuração possível no gateway da empresa.

- Interoperabilidade 
Uma vez que a criptografia é um fator fundamental e determinante em uma VPN, a interoperabilidade entre os diferentes vendedores deve ser um tópico de grande importância. Pensando nisso a IETF (Internet Engeneering Task Force), grupo diretor de engenharia da Internet, lançou o padrão IPSec (Internet Protocol Security), que codifica e encapsula os pacotes enviados através de uma rede baseada no protocolo IP (Lan Times 1998). Os produtos de diferentes vendedores devem estar de acordo com esse padrão para que possa haver interoperabilidade entre eles.

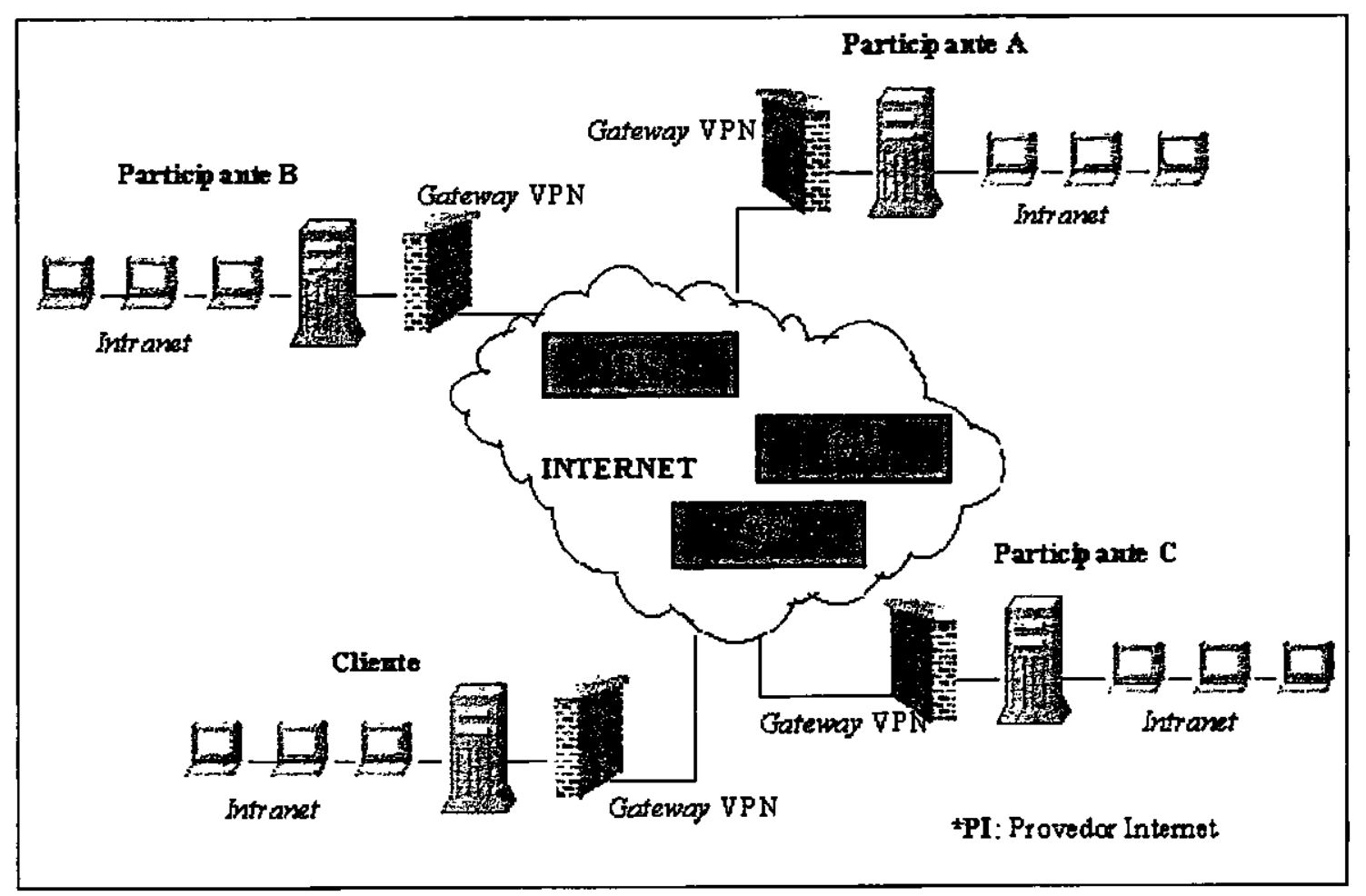

Figura 4.21. Visão de implementação de uma VPN para uma Empresa Virtual

Como o interesse deste trabalho visa a aplicação prática dos métodos de segurança de redes no auxílio à estrutura de EV's, vemos a VPN como uma tecnologia de grande ajuda, e o modelo VPN extranet é o que apresenta a estrutura que melhor se adapta a uma EV, permitindo estabelecer comunicação segura entre os seus participantes e seu cliente, cada qual mantendo sua própria estrutura de rede interna (figura 4.21). 
O gerente de um sistema computacional deve estudar suas características e escolher da forma mais adequada as opções de proteção a usar. Esse estudo sempre leva em consideração as características mais importantes na segurança do sistema, pois fica impraticável tentar usar todas as opções.

\section{Sumário}

Sistemas de Informação foram desenvolvidos para auxiliar o trabalho em uma organização. Com a criação e popularização da Internet esses sistemas adquiriram maior alcance, expandindo seus serviços para dentro e fora da empresa. Com eles ficou possível agilizar os processos, tanto os internos (ex. ordens, comunicados, transferência de dados, etc.) quanto os externos (ex. pesquisas, divulgação de produtos, etc.), e as vantagens que eles oferecem vem crescendo, tornando-os ainda mais interessantes.

Entretanto, os sistemas de informação têm se tornado vulneráveis a ataques indesejáveis. Enquanto em ambientes fechados as possibilidades de ataques eram limitadas, uma vez que esses sistemas estão se conectando aos ambientes abertos, as possibilidades de ataques crescem de forma descontrolada. Se um sistema tem ligação com a Internet ele torna-se sujeito a tentativas de ataques daqueles que ali se conectam, através de diferentes formas de vulnerabilidade que passam a apresentar. Dessa forma o risco de ataque aumenta, e com ele o interesse em conseguir manter a segurança dos sistemas.

Algumas contra-medidas foram desenvolvidas para impedir a execução de ataques, frustrando-os ou simplesmente inibindo-os. Alguns serviços de proteção visam a segurança dos sistemas em suas bases - evitar que invadam o sistema dentro da corporação - enquanto outros visam a segurança durante as transferências de dados pela rede - evitando espionagem e sabotagem através da troca de mensagens. Esses dois tipos de segurança são importantes para uma empresa, tornando necessário um estudo sobre suas prioridades para que seja tomada a melhor decisão no momento da escolha dos seus serviços de proteção. 
- 
Empresas Virtuais têm necessidade de manter seguras suas informações internas e suas comunicações. Para tanto, é interessante que se tome medidas visando a proteção de sites e de transmissão de dados que evitem a ação de intrusos. Uma tecnologia bastante difundida para a proteção de sites é o uso de firewalls, e para a proteção de transmissão usa-se criptografia. Unindo-se os dois conseguimos uma arma poderosa para as EV's, chamada VPN.

Entretanto, toda a tecnologia disponivel para se trabalhar e conseguir a segurança desejada, efetivamente pouco resolve se não for estabelecida uma boa política de segurança, tornando explícito o que é permitido ou não, o que deve, e como deve ser feito dentro da organização em termos de uso dos sistemas computacionais. Sem uma política de segurança abrangente e respeitada, os próprios usuários da empresa (funcionários, sócios, clientes, etc.) podem, intencionalmente ou não, realizar ações que acarretem prejuízos.

Neste capítulo apresentaremos uma proposta para que EV's possam usar os recursos de redes disponiveis, incluindo o uso da Internet, de forma segura. Nos apêndices A, B e C apresentamos exemplos de políticas de segurança existentes e vigentes respectivamente no ICMC-USP, na UNESP e na UNICAMP.

Como "nenhuma corrente é mais forte do que o seu elo mais fraco" e as EV's são formadas pela união de diferentes empresas em prol de um mesmo objetivo, é importante que cada empresa participante respeite a política de segurança estabelecida. Isso se faz necessário devido ao risco de que, se uma participante do grupo estiver com sua segurança fraca e for invadida, dará margem a ataques aos recursos da EV sob seu controle, bem como à toda a estrutura da EV a partir dela. Baseado nessa possibilidade, ao se formar uma EV deve existir uma política de segurança bastante abrangente, cujo cumprimento deve ser exigido àquelas empresas que pretendem se unir.

O uso de VPN's é bastante coerente quanto a prevenção contra os ataques externos (invasão ao site da empresa ou interceptação de mensagens trocadas entre os parceiros), combatendo os dois tipos de intrusão. Deve-se então obter informações a respeito do que pode ser usado, e como 
deve ser usado, para que seja conseguido um bom nivel de segurança juntamente com a funcionalidade dos recursos da rede.

\subsection{Prevenção contra Intrusão}

Para a proposta que estamos tratando neste trabalho a segurança desejada pelas EV's reflete sobre problemas de segurança na Web, o que representa tópicos diferentes para pessoas diferentes. Para alguns representa a habilidade de navegar na Web em paz. Para outros, é a habilidade de conduzir transações financeiras e comerciais de forma segura. Para os operadores de sites significa a confiança de que seus sites não serão vandalizados ou usados como portais para entrar em sua rede interna (Stein, 1998). Embora servidores Web não sejam a única porta de entrada para a rede interna de uma empresa, é uma entrada bastante visada e deve ser considerada. Em um ambiente de EV há grandes possibilidades de aproveitamento da Web. Muitos recursos podem ser usados através dela.

A fim de conseguir boa segurança deve-se tratar não somente partes isoladas, sendo preciso análise para estabelecer ações a serem realizadas cobrindo todos os pontos vulneráveis. Uma forma eficiente de se conseguir segurança é permitir o uso apenas do que constatado estritamente necessário para o bom funcionamento da rede, proporcionando acessibilidade dos usuários aos seus recursos. No caso específico de EV's, os recursos de sistemas de informação podem ser de grande utilidade, tornando sua disponibilidade bastante interessante. Para que possamos garantir essa disponibilidade é importante que protejamos bem a rede, pois quanto maior a flexibilidade e a acessibilidade de uma rede, maiores os riscos de quebra da segurança.

Precisamos saber como podemos manter os serviços, e ainda assim estabelecer boa segurança para a EV. Os serviços disponíveis para utilização através da rede podem afetar a segurança de uma empresa de duas formas distintas:

- Permitindo tais serviços pode-se deixar abertas portas por onde intrusos consigam invadir a rede interna de uma das participantes da EV, colocando em risco a EV como um todo;

- Ao ter serviços utilizados remotamente e troca de mensagens concede-se a oportunidade para interceptação de dados, que podem acarretar em perda de segredo, sabotagem ou aquisição de informação que possa levar ao acesso à rede interna de uma das participantes. 


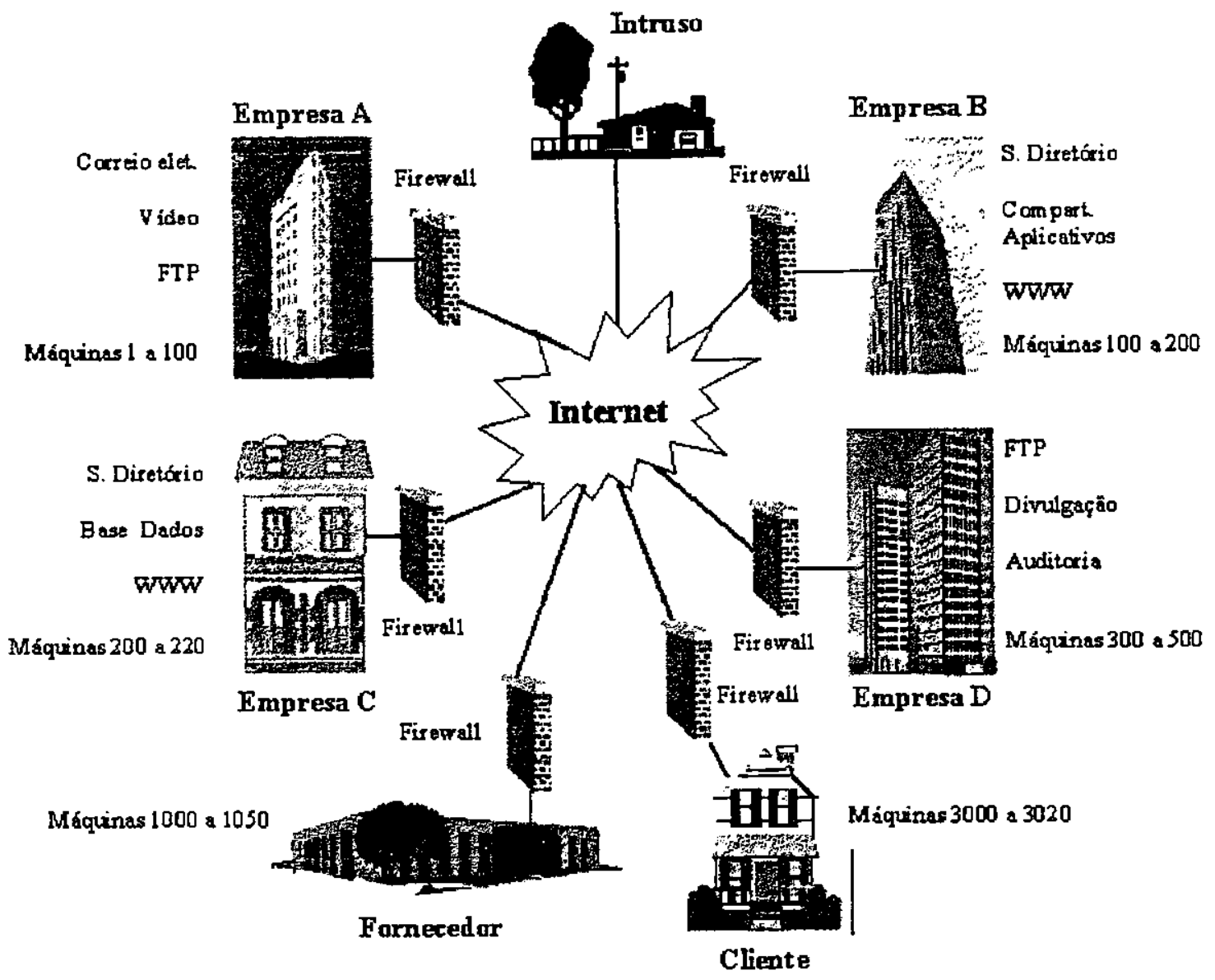

Figura 5.1. Disposição das empresas participantes da EV com proteção e alguns serviços úteis

\subsubsection{Proteção dos sites}

Vamos começar tratando da segurança dos sites das empresas participantes da EV. Aqui o principal objetivo é impedir invasões às redes dessas empresas. Uma forte arma para conseguir alcançar esse objetivo é o uso de firewalls, que filtram pacotes IP, de forma a controlar o que entra e sai da rede. Com os firewalls pode-se especificar permissões e negações de acessos de acordo com a máquina de origem, a máquina de destino e o tipo de serviço. Assim podemos escolher dar permissão de acesso apenas a máquinas confiáveis, definindo ainda que serviços essas máquinas podem acessar. Como exemplo podemos citar que uma idéia interessante é fechar a porta dos serviços de finger e telnet em todas as máquinas e fechar o serviço de FTP em algumas máquinas. 
Os serviços interessantes para as EV's são:

- correio eletrônico

- acesso a base de dados

- serviço de diretório

- seção remota

- acesso a WWW

- videoconferência

- foneconferência

- vídeo sob demanda

- compartilhamento de aplicativos

- troca de documentos

- divulgação/marketing

- auditoria

- busca na Internet

Para possibilitar o uso desses serviços é necessário que se tenha rodando servidores específicos, e que o firewall permita acesso a esses servidores. Em um ambiente de EV, não é necessário que todas as empresas participantes possuam servidores de todos os serviços. Entretanto, nada impede que duas ou mais delas tenham o mesmo tipo de servidor. Como mostrado na figura 5.1, esses servidores podem estar distribuídos entre elas. Dessa forma, cada serviço, quando utilizado, é gerenciado por uma participante. No exemplo da figura 5.1 a empresa A possui um servidor de vídeo, gerenciando seções de videoconferência e vídeo-sob-demanda. A empresa $B$, por sua vez, possui o servidor WWW, gerenciando, por exemplo, as páginas da EV.

No caso de correio eletrônico, para enviar mensagens é preciso o sendmail ou o smail, e para ler mensagens recebidas remotamente deve ser especificado a forma como deve ser feito, com pop3 ou imap. O firewall deve ser configurado de acordo com o que estiver sendo usado. Há também como filtrar os mails, evitando infortúnios como solicitações comerciais, conteúdo ofensivo, mail de pessoas indesejáveis e até risco de contaminação por vírus (NAI 1998). Existem programas que escutam a porta SMTP e, trabalhando como substituto do MTA (Mail Transport 
Agent), podem decidir repassar, descartar ou redirecionar para outro diretório, onde um humano poderia posteriormente analisar e tomar a decisão do que fazer (FSC 1999).

Para que seja possível realizar o acesso à base de dados da empresa, um usuário interno pode, através da própria rede interna, obter informações da parte que the é permitida na base. Para um usuário externo (ex. funcionário em viagem, cliente, fornecedor, funcionário de outra empresa participante da EV, etc.) entretanto, é preciso que o firewall permita o acesso pretendido. Para tanto pode ser verificado de onde vem a requisição de acesso (se é a partir de uma máquina confiável ou não), a que máquina o acesso está sendo dirigido (se é uma máquina permitida ou não) e que tipo de acesso é (ftp, telnet, www, etc.). Se estiver tudo de acordo com as regras estabelecidas no firewall, o acesso é permitido. Quando uma EV é formada, as participantes devem adaptar as regras de seus firewalls de acordo com as necessidades surgidas.

O serviço de diretório trata-se da organização e gerência de diferentes tipos de dados. O LDAP (protocolo para esse tipo de serviço) usa a porta 636, e o firewall pode controlar seu acesso, definindo permissões a máquinas especificas.

Para a disponibilização do serviço de videoconferência, bem como o de vídeo-sob-demanda, pode-se escolher entre duas formas de implementação. Uma forma é o uso de aplicativos próprios que acessam o(s) servidor(es) através de uma porta definida para esse fim. Uma vez que a escolha tenha sido feita nesse sentido, o firewall pode controlar o acesso à porta definindo o conjunto de máquinas com permissão para usar o serviço. Outra forma de implementação do serviço é através da WWW. Se essa for a forma escolhida, então a porta relativa a conexões WWW (porta 80) deve estar aberta. Uma vez que essa porta foi aberta, porém, o firewall define que máquinas podem usá-la, mas não filtram o que está passando por ela. Com isso, qualquer máquina com permissão de uso da porta WWW pode requerer o serviço de vídeo. Entretanto, ao fazer o requerimento o usuário inicia um processo responsável pelo serviço, que fará a conexão para transmissão através de outra porta que pode ser controlada pelo firewall, desde que o aplicativo seja desenvolvido para usar sempre a mesma porta. É importante dizer que outros serviços também podem ser solicitados e controlados dessa forma. 
Para o caso do serviço de foneconferência ofirewall não é aplicado. Isso deve-se ao fato da não necessidade do uso da rede pública (Internet), pois a troca de informação se dá por linha telefônica. Não quer dizer que o serviço seja isento de riscos. Grampos telefônicos podem ser feitos, acabando com o segredo da transação. Existem aparelhos que detectam a presença de grampos em uma linha, e dependendo da importância que o segredo tem para a empresa, sua aquisição pode ser relevante. Telefones sem fio são fáceis de serem "escutados" sem deteç̧ão, bastando para tanto que sua freqüência seja selecionada em radioamadores, por exemplo, o que os torna ainda menos seguros.

Para o compartilhamento de aplicações entre as empresas, cada aplicação deve ter uma porta específica a ser usada para seu contato. Assim como no caso do processo do servidor de vídeo, se as portas forem definidas fixas, é possível configurar o firewall para que essas portas dêem acesso de forma protegida. Dessa forma cada máquina poderá utilizar determinadas aplicações através das portas destinadas a elas, evitando acessos a partir de máquinas diferentes.

A troca de documentos pode ser realizada com o protocolo FTP, sobre o qual os firewalls têm controle na porta, especificando que máquinas podem requerer e que máquinas podem oferecer esse serviço. Além disso podemos definir ainda entre aquelas que podem requerer o serviço, a quais máquinas específicas pode ser requerido.

A parte de divulgação e marketing pode ser feita com diferentes meios de comunicação, como rádio, TV e Internet. Através de um site na Internet a empresa pode divulgar suas idéias, seus serviços, suas vantagens, etc. Para tanto é importante que a empresa tenha um servidor Web interno, ao qual pessoas externas possam ter acesso, ou que a empresa possua um site externamente à estrutura da empresa (ex. em um provedor independente).

Para a realização de auditoria na $\mathrm{EV}$ é interessante a aquisição de um aplicativo que consiga recolher informações a partir dos diferentes pontos relevantes do processo que está sendo desenvolvido pela EV. Esse aplicativo, entretanto, deve poder ser controlado, pois não é qualquer usuário que pode executá-lo ou ver seus resultados. Da mesma forma é interessante definir a máquina a partir da qual pode ser rodado, e conseqüentemente para onde podem ser 
enviados os dados relevantes. Uma vez definindo uma porta específica para o acesso do aplicativo às informações, ofirewall pode controlar esse acesso.

A busca na Internet é feita através do acesso à WWW, e pode ser feita pessoalmente por um usuário, ou com a ajuda de agentes móveis. O que o firewall pode controlar é que máquina pode usar a porta 80 para obter informações fora da rede, controlando assim grupos de usuários com tal acesso, uma vez que as máquinas estejam divididas por grupos de usuários. Os agentes móveis podem oferecer facilidades, mas também representar riscos. Para que possam ser usados é necessário ter rodando um servidor de agentes que permita sua entrada por uma porta determinada. O firewall pode controlar essa porta decidindo de onde podem vir os agentes, mas não tem como controlar as ações que vão executar quando tiverem entrado. Apesar de definir de onde podem vir os agentes (ex. especificando que se aceite apenas a partir de maquinas das empresas participantes da EV), uma vez que um agente externo consiga entrar em uma dessas empresas, ele pode repassar para outras. Para evitar isso, existe um método de identificação de agentes, onde as máquinas que os enviam incluem uma assinatura. Dessa forma o ambiente hospedeiro pode decidir por aceitar somente agentes que apresentem assinaturas de máquinas específicas. Além disso há como controlar as açð̃es de um agente dentro do ambiente. Qualquer agente tentando realizar ações não permitidas terá a operação barrada. Pode-se ainda estabelecer grupos de agentes com permissões definidas.

$\mathrm{O}$ acesso à WWW pode trazer para dentro da rede applets Java e ActiveX. Uma vez que vem junto com o acesso WWW o firewall não controla o que passa. Um applet Java, por exemplo, pode se aproveitar da máquina do visitante para processar dados e devolvê-los sem o consentimento do visitante. Applets podem causar craches de sistemas, browsers defeituosos, apagar dados vitais, roubar dados pessoais, etc. Pode-se evitar acessos a sites WWW não confiáveis, verificar os mails na chegada, excluindo vírus transportados juntos, desativar applets Java e ActiveX hoștis, permitindo o funcionamento dos úteis (NAI 1998), etc.

Além da preocupação em barrar invasões na porta de entrada da rede, pode-se usar a criptografia para a proteção dos dados armazenados nos servidores das empresas participantes da EV. Os dados podem ser armazenados codificados. Dessa forma, mesmo que algum intruso vença a 
barreira dos firewalls nas entradas das redes, se sua intenção era a de ler os dados da empresa, o trabalho terá sido em vão, uma vez que não compreenderá o que encontrar.

\subsubsection{Proteção das comunicações}

Uma vez que falamos sobre a proteção das redes usando firewalls, é importante falar também sobre a proteção das transmissões de dados usando a criptografia. Com ela os serviços se tornam mais seguros, pois mesmo que qualquer transação pela Internet seja interceptada, seu conteúdo não estará compreensível ao intruso, o que torna a interceptação inútil e os segredos salvos. No exemplo da figura 5.1, se a empresa D precisar realizar uma seção de video-sob-demanda (cujo servidor está na empresa A), a transmissão pode ser feita totalmente codificada mantendo a confidencialidade da informação que constitui o vídeo.

$\mathrm{Na}$ utilização do correio eletrônico pode-se passar desde algumas mensagens simples e sem muito segredo (ex. anúncio de uma viagem de visita, pedido de envio de documentos, questionamento sobre horários de plantões dos funcionários, etc.) a outras de extrema importância para o sucesso da EV, e altamente secretas (ex. fórmula do produto, nome e data de lançamento do produto, estratégia de mercado, etc.). Esse tipo de informação não deve ser do conhecimento dos concorrentes, e para garantir que eles não as tenham enquanto as mensagens são trocadas, usa-se a criptografia, codificando-as na origem e decodificando-as no destino (Queen 1999).

Assim como as mensagens do correio eletrônico, podemos proteger seções de videoconferência e video-sob-demanda, codificando os quadros transmitidos pela rede. A videoconferência pode representar na verdade uma reunião de diretoria, com segredos e estratégias sendo trocados durante toda a seção. Se algum intruso conseguir capturar, compreender esses quadros e apresentá-los a um concorrente, pode significar a ruína de todo o projeto, e talvez da própria EV.

$O$ acesso à base de dados pode transmitir também informações confidenciais (ex. um diretor consultando o lucro da empresa no último período de produção), o que justifica o uso da criptografia. Os documentos trocados entre as empresas (ex. contrato de parceria, pedido de produção de peças, acordo de aumento de salários, etc.) devem ser também protegidos, contra 
espionagem e sabotagem. A auditoria não é diferente. Esse serviço depende de dados sigilosos e precisos. Se um intruso conseguir interceptar e entender os dados necessários a essa tarefa, a empresa pode ter sua credibilidade ou sua popularidade afetadas, o que acaba por prejudicar a possibilidade de novos negócios. Pior do que isso pode acontecer se 0 intruso conseguir modificar esses dados, prejudicando o próprio serviço, o que pode levar a empresa a acreditar em uma realidade falsa, e a ações incoerentes. Tais ações podem prejudicar bastante uma empresa. $\mathrm{O}$ serviço de fone conferência não se encaixa no uso de criptografia por não fazer uso da Internet. A divulgação e o marketing não encontram o mesmo sentido em usar criptografia que os serviços citados, uma vez que a idéia referente a esse serviço é justamente alcançar o máximo de pessoas possivel, transmitindo informação, e não escondendo-a.

O processo de codificação por criptografia toma tempo, o que torna a operação mais lenta. Porém, de acordo com a importância da informação e do seu grau de segredo, esse atraso pode se tornar um preço que a EV se disponha a pagar. Pode-se amenizar esse impacto com atitudes como:

- Instituir uma máquina com processamento poderoso como servidor de criptografia - todo dado a ser transmitido pela Internet gerado pelos serviços é enviado para o servidor que faz a codificação e o libera para transmissão;

- Nos casos específicos de videoconferência e vídeo-sob-demanda, transmitir um número de quadros que se adeqüe melhor. Transmitindo um número menor de quadros codificados fica mais rápido que muitos quadros, podendo estabelecer uma velocidade mais aproximada da transmissão total sem criptografia, embora com qualidade de imagem inferior;

\subsubsection{Proteção para ambas as partes}

Além do uso de firewalls e criptografia pura nas transmissões e no armazenamento dos dados, outro fator pode aumentar o grau de segurança desse ambiente contra intrusões. Esse fator é a autenticação de usuários para a utilização dos serviços, seja por senha, assinatura digital e/ou certificação digital. Assim, ainda que um intruso consiga acesso a uma máquina considerada confiável (conseguindo dessa forma driblar a segurança do firewall e da criptografia, pois a máquina tem permissão para fazer requerimentos de serviços que passem pelo firewall e seus 
aplicativos conseguem decodificar a criptografia), ele não poderá executar qualquer serviço, não conseguindo então a informação desejada, pois sua pessoa não será autenticada. A assinatura digital tem ainda uma função de fundamental importância no que se refere ao serviço de troca de documentos, confirmando-lhes a autenticidade.

O conceito de VPN, apresentado em 4.3.15, engloba o uso de firewalls juntamente com criptografia. A idéia é unir as potencialidades dos dois para a proteção de um ambiente como o citado neste capitulo. Os firewalls protegem as redes particulares de cada empresa participante da EV, evitando a entrada de intrusos, e a troca de qualquer tipo de mensagem entre essas empresas é codificada usando criptografia na saida do firewall da rede da máquina de origem, e decodificadas no firewall da rede onde está a máquina de destino.

\subsection{Possiveis pontos de quebra de segurança}

A quebra de segurança dá-se devido a uma ou mais das três seguintes partes:

- Software;

- Administrador;

- Usuário.

Softwares mal projetados, ou mal instalados, podem deixar aberturas a serem exploradas por pessoas externas. Um software mal projetado pode deixar essas passagens, ainda que 0 administrador faça sua instalação da forma correta. Muitas aberturas são reportadas através da Internet, e "patches" de segurança são lançados a fim de corrigi-las.

Um software bem projetado também pode deixar aberturas caso não seja instalado e configurado corretamente pelo administrador. Para evitar isso, o administrador deve certificar-se da forma correta de instalação e configuração, além de instalar posteriormente as patches lançadas para aquele software, visando sempre manter a boa segurança da rede. Esse profissional deve também estar sempre verificando, com o uso de ferramentas de scan, se não houve alterações nas configurações ou instalações de novos softwares que possam deixar portas abertas. Optando por uma política de privilégios mínimos, as chances de estrago são reduzidas, além de se tornarem 
menores as implicações dos estragos que os usuários causarem. Deve-se também fazer backup constantemente.

Por último, o usuário deve ser bem treinado para utilizar os recursos da rede de forma correta, e prezar pelo bom funcionamento da mesma, além das prevenções contra quebra de segurança, como:

- Cuidado com ações durante navegação pela Internet, principalmente com passagem de informação;

- Cuidado com a engenharia social (trapaça, conto do vigário, enganação).

\subsection{Política de segurança}

A política ajuda a definir o que é considerado valioso, e especifica os passos para conservar sua atividade (Spafford 1996). Pode ser formulada de diferentes formas. Pode-se escrever uma política geral, simples, de poucas páginas que cubra a maioria das possibilidades. Pode-se quebrar uma política por diferentes conjuntos de atividades. Pode-se ter uma política simples e pequena com padrões e diretrizes para um comportamento apropriado. A política de segurança não deve listar tarefas, máquinas ou indivíduos específicos pelo nome. Deve ser genérica e mudar pouco no decorrer do tempo.

É através dela que definem-se normas a serem seguidas por aqueles que têm acesso aos recursos da rede. Assim, podemos tentar evitar que usuários internos, de alguma forma (consciente ou não), abram caminho para invasões externas, ou ainda que eles mesmos realizem algum procedimento indevido. Falaremos agora sobre uma politica para empresas (que pode ser estabelecida internamente às participantes de uma EV) e mais abaixo alguns tópicos relativos à estrutura especifica de EV's.

Para estabelecer uma boa política de segurança podemos dividi-la em alguns tópicos como:

- Deixar claro o que está sendo protegido e especificar a responsabilidade pela proteção;

- Estipular segurança fisica dos equipamentos pertencentes à empresa;

- Definir serviços oferecidos e permitidos aos usuários da rede;

- Estabelecer ações permitidas sobre os equipamentos da rede; 
- Definir punições cabiveis;

\subsubsection{Deixar claro o que está sendo protegido e especificar a responsabilidade pela proteção}

Apresentando o que está sendo protegido, e especificando a responsabilidade dessa proteção, pode-se facilitar a compreensão e o cumprimento da política. Exemplo:

- Os equipamentos da empresa e as informações neles contidos representam um recurso crítico para a Jbe Corporation. Os equipamentos e as informações devem ter proteção correspondente aos seus valores para a Jbe, e consistente com as leis cabiveis. Todos os empregados compartilham a responsabilidade pela proteção e supervisão dos equipamentos $\mathrm{e}$ das informações produzidas, manipuladas, recebidas ou transmitidas em seus departamentos. Todos os empregados igualmente compartilham a responsabilidade pela manutenção, operação apropriada, e proteção de toda informação usando recursos da Jbe.

\subsubsection{Segurança fisica dos equipamentos pertencentes à rede}

A primeira decisão importante é referente a segurança fisica dos equipamentos da rede. Dentro desse tema deve-se definir:

- Local fisico para os equipamentos: evitar que pessoas estranhas consigam entrar em contato com os equipamentos;

" onde serão instalados?

- o local é seguro contra invasão fisica?

- haverá divisões, ou todos os equipamentos estarão em um mesmo local, como mesma sala ou mesmo prédio?

- Acesso fisico ao local: quem pode chegar até os equipamentos;

- como serão atribuídas e verificadas as autorizações para entrar no estabelecimento (reconhecimento pessoal, cartão magnético, dispositivo com senha, crachá, etc.)?

- somente funcionários podem ter acesso à rede, ou haverá outro tipo de usuário (cliente, fornecedor, parentes, etc.)?

- haverá distinção entre grupos diferentes de usuários relativa a acesso a grupos diferentes de equipamentos, ou todo usuário poderá acessar qualquer equipamento? 
- Inspeção do local: vigilância ;

- será instalado algum dispositivo de auxílio à segurança (sistema interno de câmeras de vídeo, alarmes em portas e janelas, alarmes com laser, para o horário em que não deve haver ninguém no local, etc.)?

- haverá contratação de uma companhia de segurança, ou de um segurança humano para vistoriar e proteger o local?

- Proteção contra desastres como fogo, terremoto, maremoto e tempestades.

Uma boa segurança fisica para os equipamentos deve prever:

- Divisão física para equipamentos, determinando grupos de usuários a equipamentos específicos, de acordo com as necessidades de cada grupo;

- aqui é importante que apenas o(s) administrador(es) tenha(m) acesso fisico aos servidores, roteadores, e à máquina que desempenhará o papel de firewall do sistema, estando esses em local separado.

- Somente os funcionários devem ter acesso aos equipamentos da rede. A intenção é evitar manipulação dos mesmos por pessoas estranhas à empresa, que podem ter motivos desconhecidos para prejudicar os equipamentos, ou ainda falta de conhecimento de como manipulá-los, podendo causar danos, mesmo não intencionalmente;

- É sempre bom possuir mecanismos de segurança que possam ajudar a evitar e/ou identificar uma invasão;

- para o caso de um estabelecimento em que sempre há movimento de pessoas trabalhando, o uso de alarmes em portas, janelas ou mesmo laser, se torna inviável. O sistema interno de vídeo continua sendo uma boa opção, permitindo inspeção constante do local.

- Um segurança humano pode ajudar a barrar um invasor ou detê-lo se a invasão já tiver sido efetuada.

- serviço de vídeo pode ser ineficiente se não houver ninguém inspecionando-o e o invasor entrar disfarçado, por exemplo, com uma máscara evitando sua identificação.

- As proteções contra desastres podem garantir a integridade dos recursos da empresa;

- Paredes contra fogo podem salvar os recursos em uma situação de incêndio, seja ele acidental ou não. Essa possibilidade pode não ser muito remota, principalmente em locais propensos a conflitos como guerras e/ou rebeliões; 
- Boas fundações e instalações firmes podem proteger os equipamentos contra possíveis quedas ou contatos com fragmentos danosos em uma situação de terremoto;

- Conforme proximidade com mares e oceanos (ou até sendo no meio desses), pode ser interessante que se tome cuidados contra maremotos. Esses cuidados podem incluir uma boa vedação das instalações, ou mesmo a escolha de outro ponto mais afastado para essas instalações;

- Tempestades acontecem com uma freqüência maior entre os desastres citados aqui, e exige também certos cuidados.

$>$ Uma boa vedação do local é importante para que a água não entre e danifique os equipamentos;

$>$ Uma boa estabilização da rede elétrica pode proteger os equipamentos contra variações de tensões que ocorrem devido às descargas elétricas da tempestade.

\subsubsection{Serviços oferecidos e permitidos aos usuários da rede}

Deve-se estabelecer quais serviços serão oferecidos àqueles que utilizam a rede e coibir o uso de outros. Isso se dá devido às possibilidades de exploração de aberturas na segurança crescerem conforme o crescimento do número de serviços. Além disso, um número maior de serviços abre espaço para que usuários internos tentem usufruir de um serviço sem conhecimento suficiente, podendo causar problemas. Uma boa opção então é manter apenas o necessário, e treinar os usuários para que os utilizem da forma correta.

A fim de decidir que serviços estarão presentes, deve-se levar em conta que tipo de trabalho é realizado por cada grupo de usuários, e que tipo de acesso esses trabalhos requerem (acesso interno à parte do grupo na rede, acesso à toda a rede interna, acesso à rede externa, acesso externo à rede interna total ou parcial). Com esses dados em mãos pode-se definir que restrições devem ser estipuladas às diferentes partes da rede.

Para exemplificar podemos usar o modelo de uma indústria com linha de montagem. $O$ gerente da indústria pode ter acesso a toda a rede interna da empresa, com o intuito de verificar como vai o andamento da mesma nos diferentes setores, e à rede externa para comunicação com outras filiais, com a matriz, com fornecedores, etc. $O$ gerente da linha de montagem, por sua vez, 
precisa de acesso apenas à sua parte da indústria, podendo verificar horário de chegada dos seus subordinados, velocidade da montagem, acidentes de trabalho, etc. e acesso externo à sua divisão apenas para se comunicar com o gerente geral. Assim podemos restringir o acesso do gerente da linha de montagem, de forma que ele não possa se envolver com setores diferentes, como o financeiro, o de pessoal, ou o de marketing.

O acesso aos serviços da rede deve ser restrito aos funcionários (assim como o acesso físico aos equipamentos). Pode-se restringir o acesso com autenticação do usuário. Uma forma bastante difundida para esse fim é o uso de senhas, podendo também ser realizado através de cartões eletrônicos, reconhecimento de voz, assinatura digital, etc. Com a autenticação do usuário consegue-se permitir e controlar acessos não somente internos, mas também externos, por exemplo, através da Internet. É importante ressaltar também que, embora os usuários possam acessar os servidores através da rede, somente o(s) administrador(es) deve(m) poder alterar suas configurações e ter acesso ao firewall, mesmo que remotamente.

\subsubsection{Ações sobre os equipamentos da rede}

Outro fator a ser determinado é o que os usuários será ou não permitido sobre os equipamentos da rede, como por exemplo:

- Será permitido que algum funcionário leve algum equipamento para casa?

- O funcionário terá permissão para desmontar algum equipamento?

- Poderá haver troca de peças de equipamentos pelos funcionários?

- O funcionário poderá trazer equipamento de casa para usar junto à rede?

Uma boa resposta para essas perguntas é "não".

1. Podendo levar equipamento para casa o usuário pode expô-lo a fatores prejudiciais como:

- Transporte indevido, causando danos físicos;

- Uso por pessoas sem o devido conhecimento (filhos, cônjuge, amigos, etc.), podendo danificar o funcionamento, mesmo não intencionalmente (ex. retirando ou instalando programas com vírus em um computador);

- Maior risco de roubo, uma vez que a segurança do local tende a ser menor; 
- Uso por pessoas maliciosas, que não conseguiriam entrar na empresa, podendo obter informações sigilosas, ou danificar o próprio equipamento;

- Por fim, o próprio usuário pode ter intenção de roubar o equipamento, ou facilitar seu acesso a terceiros.

2. Podendo desmontar equipamento o usuário pode causar problemas como:

- Danos fisicos ao equipamento ou seus componentes;

- Perda de peças;

- Não conseguir remontar adequadamente, prejudicando seu funcionamento.

3. Podendo fazer troca de peças nos equipamentos o usuário pode causar:

- Danos físicos às peças, seja na retirada de um equipamento, na colocação em outro, ou no transporte entre um e outro;

- Instalação de peças não compatíveis;

- Perda de peças;

- Referências erradas sobre a localização das peças;

4. Trazendo equipamento próprio para usar junto à rede o usuário pode expor a rede a:

- Contaminação (ex. por vírus, a partir de softwares instalados em um computador pessoal que o usuário tem em casa e trouxe para dentro da rede)

- Troca de peças com equipamentos da rede, melhorando o equipamento pessoal, mas deteriorando os da empresa.

- Invasões externas via rede, uma vez que o equipamento particular do usuário não necessariamente terá instalado os mecanismos de segurança presentes nos equipamentos da empresa, aumentando as possibilidades de furo de segurança.

O ideal é que apenas o administrador e/ou um técnico da empresa (dependendo da necessidade) possam desmontar ou trocar peças dos equipamentos. Porém, nem mesmo esses devem poder levar equipamento para fora da empresa, ou trazer equipamento particular para uso junto à rede.

\subsubsection{Punições}


Quase nunca basta a divulgação de normas que definam o que pode ser prejudicial, pois nem sempre todos os usuários prezam pelo bom funcionamento da empresa, ou ainda, por manter seus segredos. Além de divulgar o que é permitido ou não, deve-se também estabelecer punições relativas ao não cumprimento das regras, visando com isso fazer com que todos cumpram o determinado, sob pena de ações previstas.

As punições, a serem aplicadas àqueles que desrespeitarem as regras, devem ser muito bem estudadas, caso a caso. Para cada tipo de desobediência deve-se encaixar um tipo de punição, fazendo com que os usuários se sintam desencorajados a praticarem tal ato. Essas punições podem, e costumam, variar entre:

- Advertência verbal;

- Advertência escrita e registrada;

- Multa;

- Suspensão temporária;

- Rebaixamento de cargo na empresa;

- Demissão;

- Processo judicial.

Em alguns casos especificos previstos e estipulados pode-se conceber a adaptação de partes da política de segurança para a situação em questão. Como exemplo podemos citar que um determinado projeto requeira a apresentação de resultados parciais aos diretores da empresa cliente, que não possui os recursos necessários. Nessa situação é preciso a retirada de equipamento próprio da empresa por um funcionário a fazer a apresentação. Essa ocorrência deve ser coberta por regras explícitas que a permita, bem como estipula os procedimentos de verificação a serem realizados quando da voita do equipamento, fiscalizando sua integridade $e$ bom funcionamento. Além disso deve existir a autorização de um responsável (ex. gerente de projeto, chefe do almoxarifado, etc.).

Para o âmbito de EV's existem mais algumas características. Além dos itens mencionados para tratar da segurança de uma empresa, podemos ainda contar com normas relativas a:

- Será permitida a locomoção de equipamentos entre as participantes? 
- Algum equipamento de uma participante poderá ser retirado de suas instalações para fins da EV?

- Funcionários de uma das participantes poderão ter acesso físico às instalações de outras?

- Funcionários de uma das participantes poderão ter acesso a serviços ou informações de outras?

- Qual o requisito mínimo de segurança a ser cumprido pelas participantes?

O sucesso na execução do projeto pode requerer algumas concessões especiais por parte das participantes (concessões que normalmente a empresa não permitiria). Para tanto é necessário que estejam previstas e explícitas à todas as participantes no ato da formação da EV.

- A locomoção de equipamentos pode ser vantajosa em determinadas situações;

- Por exemplo: parte do projeto pode requerer alto poder de processamento. Algumas máquinas da empresa participante $A$ podem então ser transportadas e somadas temporariamente à estrutura da empresa participante $B$ a fim de cumprir essa etapa.

- Além da locomoção de equipamentos entre as participantes, pode se tornar necessária a retirada de algum equipamento para locais alheios aos ambientes das participantes;

- Pode ser interessante a promoção das atividades da EV em congressos e simpósios, exigindo equipamentos de demonstração ou de testes no local. Alguma participante deverá liberar, por exemplo, um computador, um projetor, alguns cartazes, modelos de projetos, etc.

- Muitas podem ser as situações em que um funcionário de uma das participantes precise entrar em outra(s);

- Consultorias podem ser dadas;

- Reparos podem ser executados;

- Reuniões podem ser realizadas;

- etc.

- O acesso a serviços e informações de uma participante por funcionários de outra(s) deve ser realizado única e exclusivamente para propósito do projeto e apenas às partes previamente acertadas e permitidas; 
- Um requisito minimo de segurança deve ser estipulado e exigido como condição a ser cumprida para a aceitação de participantes, evitando que alguma delas funcione como elo fraco da corrente.

- Aqui, por exemplo, pode-se exigir que toda empresa a participar possua um firewall, evitando invasões e acesso aos dados da EV, ou mecanismos contra o $\mathrm{Y} 2 \mathrm{~K}$ (o bug do milênio), evitando falhas durante o processo.

\section{Sumário}

Se as empresas que decidirem se organizar como EV se conscientizarem de que o aspecto "segurança" é de grande importância para seu sucesso, um grande passo já foi dado para que seus processos sejam seguro. A partir dessa convicção, mostramos um ambiente com serviços úteis à EV, e uma forma de deixar esses serviços funcionais e seguros. Somando aos cuidados necessários para que não ocorram acidentes ou intrusões no ambiente de empresas, virtuais ou não, são descritos aspectos de política de segurança, que de diferentes formas contribui para a segurança total da corporação. 
As Empresas Virtuais estão despontando como alternativa interessante para que Pequenas e Médias Empresas alcancem um mercado antes inacessível. Através da união entre empresas parceiras, consegue-se constituir capacidades fortes e oferecer competitividade no mercado até então pertencente a grandes empresas.

A união entre empresas diferentes demanda serviços de um bom Sistema de Informação, que possa auxiliar o desenvolvimento desse processo. Faz-se necessário um bom gerenciamento de recursos incluindo equipamentos, dados, informaçōes, comunicações, etc. Tal necessidade requer uma infra-estrutura de suporte aos serviços. Os serviços, por sua vez, demandam segurança que garanta a confidencialidade, integridade e disponibilidade dos recursos da EV (incluindo suas informações).

Garantir a segurança em um âmbito de EV's implica, antes de tudo, na visualização do sistema de informação e seus serviços, entendendo seus pontos úteis e seus pontos de risco. A estrutura da EV apresenta peculiaridades que exigem estudo detalhado. Uma das dificuldades enfrentadas neste trabalho foi encontrar a compreensão da estrutura de EV's, entender seu processo e mapear os serviços úteis a diferentes pontos desse processo.

Com este trabalho tentamos mostrar as possibilidades do uso de serviços computacionais em Empresas Virtuais, alertar para pontos de vulnerabilidades que podem permitir danos às suas atividades e/ou à sua estrutura, e apresentar opções que garantam uma estrutura segura para o desenvolvimento de seus projetos com sucesso.

Em se tratando de ambientes computacionais, não se alcança $100 \%$ de segurança. $O$ que podemos fazer é nos adaptarmos à situações, realizando esforços para disponibilizar recursos evitando que isso crie possibilidades de prejuízos.

"Segurança não é uma solução, é um meio de vida!" (Kurt Seifried) 
(Arellano 1998) Arellano, Kevin : "CORBA 10I" http://holly.colostate.edu/ kpa/corba/corba.html - October 9, 1998

(Atkinson 1995a) Atkinson, R.: "IPv6 Security Architecture" - Internet Draft, March 1995.

(Atkinson 1995d) R. Atkinson: "IP Authentication Header" - Internet Draft, March 1995.

(Atkinson 1995c)

R. Atkinson: "IPng Encapsulating Security Payload (ESP)" Internet Draft, March 1995.

(Beck 1997) Beck, R.: "Mime Format" - The Newsletter of the Greater Victoria PC Users' Association - Web Edition - Volume 15, Number 4, May 1997 http://www.islandnet.com/ bigblue/may $97 \mathrm{ml} / \mathrm{mime}$. htm

(Bonifácio 1997) Bonifácio Jr., J. M. — "Sistema de Segurança Distribuido: Integração de Firewalls a Sistemas de Detecção de Intrusão" Projeto de Dissertação de Mestrado ICMSC/USP - São Carlos 1997

(Bonifácio et. al. 1998a)

Bonifácio Jr, J. M.; Cansian, A.; Carvalho, A. C. P. L.F de; Moreira, E. S.: "An Adaptive Intrusion Detection System Using Neural Networks" - Submetido ao IEEE Infocom'98, 17 $7^{\text {th }}$ Annual Joint Conference of the IEEE Computer and Communications Societies, São Francisco, EUA, April, 1998.

(Bonifácio et. al. 1998b)

(Bosselaers 1995) Bonifácio Jr, J. M.; Cansian, A.; Carvalho, A. C. P. L.F de; Moreira, E. S.: "Neural Networks Applied in Intrusion Detection Systems" - Submetido ao IJCNN '98 International Joint Conference on Neural Networks, Anchorage, Alaska, May, 1998.

Bosselaers, A.; Preneel, B.: "Integrity Concepts" - Lectures Notes in Computer Science 1007 - Integrity Primitivies for Secure Information Systems - Part II - pp 9-22 - Ed. Springer - 1995

(Borenstein 1992) Borenstein, N. S.: "Internet Multimedia Mail with MIME: Emerging Standards for Interoperability" http://www.pha.jhu.edu/ nils/Other/MIME-overview.txt - May, 1992

(Borenstein et. al. Borenstein, N; Thyberg, C. "Power, Ease of Use, and Cooperative 1991)

(Bradshaw 1997) Work in a Practical Multimedia Message System", International Journal of Man-Machine Studies, April, 1991.

(Bremer 1997)

Bradshaw, J. M.: "Software Agents" - MIT Press - 1997

Bremer, C. F.: "Gestão de Produção de Empresas Virtuais (PREVIRT)" - Projeto integrado de pesquisa CNPq -

Universidade de São Paulo / Escola de Engenharia de São Carlos / Departamento de Engenharia Mecânica / Área de Engenharia de Prođução - 1997

(Bremer et. al. 1998) Bremer, C. F., Eversheim, W., Waltz, M., Gutierrez, A. M. "Global Virtual Business - A Systematic Approach for Exploiting Business Opportunities in Dynamic Markets" - 1998 
(Cansian 1997) Cansian, A. M.: "Um Sistema Adaptativo de Deteç̧ão de Intrusão em Redes de Computadores" - Projeto de Tese de Doutorado IFSC/USP - São Carlos - 1997

(Cansian et. al. Cansian, A. M.; Moreira, E. S.; Carvalho, A. C. P. L. O. de; 1997a) Bonifácio Jr., J. M.: "Network Intrusion Detection Using Neural Networks" - In Proc. Of International Conference on Computational Inteligence and Multimedia Applications, ICCIMA'97, Gold Coast, Australia, pp 276-280, Feb. 1997.

(Cansian et. al. Cansian, A. M.; Moreira, E. S.; Mouro, R.; Morishita, F. T.; 1997b) Carvalho A C. P. L. O. de: "An Adaptative System for Detecting Intrusion in Networks" - In Proceedings of the III International Congress on Information Engineering, Buenos Aires, Argentina, pp 96-105, April 1997.

(Cansian et. al. Cansian, A. M.; Moreira, E. S.; Bonifácio Jr., J. M.; Carvalho, A. C. 1997c) P. L. O. de : "Modelo Adaptativo para Deteç̧ão de Comportamento Suspeito em Redes de Computadores". - In the Proc. Of the XV Brazilian Symposium on Computer Networks, SBRC'97, pp 51-60, São Carlos, SP, May 1997.

(Check Point 1998a) Check Point Software Technologies Ltd. 1998 - "Redefining the Virtual Private Network" - A Technical White Paper P/N 31400000100 - March 4, 1998 - http://www.checkpoint.com

(Check Point 1998b) Check Point Software Technologies Ltd. 1998 - "Virtual Private Network Security Components" - A Technical White Paper P/N 3140000200 - March 23, 1998 - http://www.checkpoint.com

(Chess et al. 1995)

Chess, D.; Grosof, B.; Harrison, C.; Levine, D.; Parris, C.: "Itinerant Agents for Mobile Computing" - IBM, Março 1995. (Relatório Técnico RC20010).

(Crosbie \& Spafford Crosbie, M.; Sppafford, E. H.: "Defending a Computer System using 1995)

(Curtis 1997)

(Data Connection 1999)

(Diffie et. al. 1976)

(Ferreira 1988)

(Forsdick et. al. 1984)

(Frawley 1992) Autonomous Agents" - Department of Computer Sciences, Purdue University, 1995 (Relatório Técnico CSD-TR-95-022; Coast TR 95-02) http://www.cs.purdue.edu/homes/spaf/tech-reps/9522.ps. Curtis, D. - "Java, RMI and CORBA" - 1997 http://object.des.fmph.uniba.sk/ODMG/java_rmi_and_corba/wpj ava.htm

Data Connection: "Directory Services - The role of $L D A P$ and X.500" - http://www.datcon.co.uk/press/mdwhitel.htm

Diffie, W.; Hellman, M.E. : "New Directions in Criptography" "IEEE Trans. On Information Theory", vol. IT-22, pp 644-654 Nov. 1976

Ferreira, A. B. de H.; "Dicionário Aurélio Básico da Lingua Portuguesa" - Editora Nova Fronteira S/A, 1988

Forsdick, H.C.; Thomas, R.H.; Robertson, G. G.; Travers, V. M.: "Initial Experience with Multimedia Documents in Diamond", Computer Message Service, Proceedings IFIP 6.5 Working Conference, IFIP, 1984.

Frawley, W.; Piatetsky, G.; Matheus, C.: "Knowledge Discovery in Databases: An Overview" - AI Magazine, Fall 1992, pgs 213- 
(FSC 1999)

(Fuggeta, Picco \& Vigna 1998)

(Garon et. al. 1997)

(Giel 1997)

(Harrison et. al. 1995)

(Harrison, Chess \& Kershenbaum 1997)

(Hinden 1998)

(Hinden 1995)

(Horstmann et. al. 1997)

(Intermec 1999)

(ISO 1997)

?.

(ISO 1997a)

(Kahn 1967)

(kay 1984)

(King, Christopher

M. 1999)

(Lai 1990)
228.

Firewall Security Corporation: "What is Ironhand?" - 1999 http://www.ironhand.net/is_it.html

Fuggeta, A.; Picco, G. P.; Vigna, G: "Understanding Code Mobility" - In: IEEE Transactions on Software Engineering, vol. 24, no. 5, p.342-361. Maio 1998.

Garon, J.; Herscher, S: "Embedded CORBA" - 1997 http://www.expersoft.com/Resources/WPapers/embed_corba.htm Giel, W.: "A JavaTM implementation of the Digital Signature Standard" - KC Multimedia and Design Group, Inc.- 1997 http://www.digitalkey.com/

Harrison C. G.; Chess D. A.; Kershenbaum, A.: "Mobile Agents: Are they a good idea?" - Research Report - IBM T.J. Watson Research Center - Março 1995 http://www.research..ibm.com/massive/mobag.ps

Harrison, C. G.; Chess, D. M.; Kershenbaun, A.: "Mobile Agents: Are they a good idea?" In: Mobile Object Systems: Towards the Programmable Internet. (ed) Vitek, J.; Tschudin, C. Lecture Notes in Computer Sciences, vol. 1222. p.25-47. Springer Verlag. 1997. Disponível também como Relatório Técnico da IBM. WWW: http://www.research.ibm.com/iagents/paps/mobile_idea.ps.

Hinden, R.: "IP Next Generation (Ipng)" - 1998 http://playground.sun.com/pub/ipng/html/ipng-main.html

Hinden, R.: "IP Next Generation Overview" - 1995 http://playground.sun.com/pub/ipng/html/INET-IPngPaper.html\#CH10

Horstmann, M.; Kirtland, M.: “DCOM Architecture” - July 23, 1997 http://msdn.microsoft.com/library/backgmd/html/msdn_dcomarc h.htm

Intermec Technologies Corporation - "SNMP (Simple Network Management Protocol)" http://www.intermec.com/datactr/snmp.htm

ISO/IEC JTCI/SC29/WG11 N1909 - "Overview of the MPEG-4 Version I Standard' - 1997 http://drogo.cselt.stet.it/mpeg/public/w1909.htm

ISO/IEC JTC1/SC29/WG1 1 N1921 - "Third Draft of MPEG-7 Requirements" - 1997 http://drogo.cselt.stet.it/mpeg/public/w1921.htm

Kahn, D.: "Cryptology Goes Public" - IEEE Commun. Magazine, vol. 18, pp. 19-28, March 1980

Kay, A: "Computer Software" - Scientific American 251(3):53-59 $-1984$

King, C. M.: "The 8 Hurdles to VPN Deployment" - In: Information Security - A world of information for the security concious 1994 - http://www.infosecuritymag.com/mar99/cover.htm

Lai, X.; Massey, J.: "A proposal for a New Block Encription Standard" - "Advances in Cryptology-Eurocrypt '90 
(Lai 1992)

(Lan Times 1998)

(Macquarie 1995)

(Marque 1997)

(Mensaging Direct 1999)

(Microsoft 1996)

(Microsoft 1998

(Microsoft 1998b)

(Mowbray 1998)

(Mshug 1998)

(Netscape 1997a)

(Netscape 1997b)

(Netscape 1997c)

(NIT 1998)

(Nwana \&

Wooldridge 1996)
Proceedings" - New York: Springer Verlag - pp 389-404, 1990

Lai, X.: "On the Design and Security of Block Ciphers" - Konstans Germany: Hartung -Gorre, 1992

LANTIMES BRASIL / vol. 4, Edição 39 / págs. 20,21 / 23-11-1998

Macquarie University - "What are the Directory and X500" http://www.mq.edu.au/X500/Use/whatisx500.html - 1995

Marque, N. R. de: "WEBank e Segurança" - Projeto de estágio de conclusão do curso de Bacharelado em Ciências de Computação pela USP - São Carlos : 1997

Mensaging Direct - "How to Build an Enterprise Directory with LDAP and X.500" http://www.messagingdirect.com/publications/IC-6040.html

Microsoft Corporation - "DCOM Technical Overview" http://msdn.microsoft.com/isapi/msdnlib.idc?theURL=/library/ba ckgrnd/html/msdn_dcomtec.htm

Microsoft Corporation - "DCOM" http://eu.microsoft.com/com/tech/DCOM.asp

Microsoft Corporation - "Distributed Component Object Model Protocol -- DCOM/l.0" http://msdn.microsoft.com/library/specs/distributedcomponentobj ectmodelprotocoldcom 10. htm

Mowbray, T. J. - "The Trouble with DCOM, COMplus, and CORBA" -

http://www.objectnews.com/corba_opinion_050898.htm - May $15^{\text {th }}, 1998$

Microsoft Europe and Microsoft Healthcare Users Group Europe "Increasing Interoperability and Lowering Costs with Active X" for

Healthcare" - http://www.mshug-euro.org/whitepaper 1.html\#3.2

Network Associates, Inc: "WebScanX $®$ Protection from hostile Java and Active X applets" - 1998 http://www.axial.co.uk/NAI/av/webscanx.html

Netscape - "SSL 3.0 SPECIFICATION" - 1997 http://home.netscape.com/eng/ssl3/index.htm

Netscape - "Planning and Deploying a Single Sign-On Solution" 1997 -

http://developer.netscape.com/library/documentation/security/SS $\mathrm{O} / \mathrm{sso}$.htm

Netscape - "Netscape's Use of Public-Key Cryptography" - 1997 http://developer.netscape.com/docs/manuals/security/SSO/crypt. htm

Network Information Technology - "Single Sign-On (SSO)" - 1998 - http://www.nit.com/products/sso.html

Nwana, H.; Wooldridge, M.: "Software Agents Technologies" In: BT Technology Journal, vol. 14, no. 4, p68-78. Outubro 1996. WWW:

http://www.labs.bt.com/projects/agents/publish/papers/satreport. $\mathrm{htm}$ 
(NWF 1998) Network World Fusion - "Implementing IPv6-Migrating Your Internetwork to the Next Generation Internet Prolocol" - 1998 http://www.nwfusion.com/seminars/ipv6/overview.html

(OMG 1995) OMG - "CORBA Overvlew" http://pent21.infosys.tuwien.ac.at/Research/Corba/OMG/arch2.ht m

(Open Horizon 1998)

(Orion 1999)

(Pfitzmann 1996)

(Queen 1999)

(Reami 1998)

(Rivest et. al.1978)

(Rodrigues 1999)

(RSA 1998a)

(RSA 1998b)

(RSA 1997)

(Sander \& Tschudin 1998b)

(Schmidit 1999)

(Schutter 1993)

(Seifried 1999)

(Softools 1998)
Open Horizon - "Inlegrating Network, Application, and Database Authenticalion into a Standards-based Framework' - 1998 http://www. openhorizon.com/html/sssowp.html

Orion Consulting Ltd. - "While Paper - EDI and EC" - 1999 http://www.orionltd.co.uk/reference/edi-and-ec.htm

Pfitzmann, B. - "Digital Signature Schemes" - Lectures Notes in Computer Science 1100 - Ed. Springer - 1996

Queen, Nat. M.: "Introduction lo PGP" - 1999 http://sun 1.bham.ac.uk/N.M.Queen/pgp/pgp.html

Reami, E. R. - "Especificação e Prototipagem de um Ambiente de Gerenciamento de Segurança Apoiado por Agentes Móveis". dissertação de mestrado do Instituto de Ciências Matemáticas e de Computação da Universidade de São Paulo (ICMC-USP) 1998

Rivest, R. L.; Shamir, A.; Adleman, L.: “On a Method of Obtaining Digital Signatures and Public Key Cryptosystems" -

“Community of $A C M$ " - vol. 21, pp. 120-126 - Feb. 1978

Rodrigues, E. J. - "Uma modelagem para Comércio Eletrônico usando CORBA e Agentes Móveis" - dissertação de mestrado do Instituto de Computação da Universidade Estadual de Campinas (IC-UNICAMP) - 1999

RSA Data Security, Inc - "S/Pay TM - The Sel Toolkit" - 1997 http://www.rsa.com/rsa/products/spay/

RSA Data Security, Inc - "The 1998 RSA Data Security Conference" - 1998 - http://www.rsa.com/conf98/html/poster.html

RSA Data Security, Inc - "Security in the SET Prolocol" - 1998 http://www.rsa.com/set/html/security.html

Sander, T.; Tschudin, C.F. "Towards Mobile Criptography". In: Proceedings of IEEE Security \& Privacy '98. Oakland, California, Maio 1998. WWW: http://www.icsi.berkeley.edu/ sander/publications/satschu.ps

Schmidt's, D. C.: "Distributed Object Computing with CORBA Middleware" - 26 February 1999 http://www.cs. wustl.edu/ schmidt/corba-overview.html -

Schutter, B. de: "Trends in the Figth Against Computer-Related Delinquency" - Lectures Notes in Computer Science 741 Computer Security and Industrial Cryptography - Section 1, pp 3-19-Ed. Springer-Verlag - 1993

Seifried, Kurt: Linux Administralors Security Guide - 1999 https://www.seifried.org/lasg/

Softools - "Single Sign On" - 1998 http://www.softools.fr/SSO_e.htm 
(Spafford 1996) Spafford, G.; Garfinkel, S.: "Pratical Unix and Internet Security" O’Reilly \& Associates, Inc - Second Edition - 1996

(Stair 1996) Stair, Ralph M.: "Principios de Sistemas de Informação - Uma Abordagem Gerencial " - JC editora - Segunda Edição - 1996

(Stein 1998) Stein, Lincoln D.: "Web Security / A Step-by-Step Reference Guide" -Addison Wesley - 1998

(Sun 1995) Sun Microsystems - "The NFS Distributed File Service" - March 1995 - http://www.sun.com/software. white-paper/wp$\mathrm{hfs} / \mathrm{nfs}$ 18.htmi \#H2_100049

(Tanenbaun 1996) Tanenbaun, A. S. - "Computer Networks" - Ed. Prentice Hall Third Edition - 1996

(Tribeca 1997) Tribeca Tecnologies - "A White Paper On MPEG, an Overview" 1997 - http://www.tribecatech.com/MPEGwhit.htm

(Trickey 1997) Trickey, F. - "Secure Single Sign-On: Fantasy or Reality?" Columbia University, CSI Advisory Council. http://www.gocsi.com/sso_ft.htm

(Vitek, Serrano \& Thanos 1997)

Vitek, J.; Serrano, M.; Thanos, D.: "Security and Communications in Mobile Object Systems" In: Mobile Object Systems: Towards the Programmable Internet. (ed) Vitek, J.; Tshudin, C. - Lecture Notes in Computer Sciences, vol. 1222. Springer Verlag. 1997. WWW: http://cuiwww.unige.ch/OSG/people/jvitek/Publications/tpi.ps.gz

(XOC 1996ª $\quad$ X/Open Company Limited - "Introduction to Single Sign-On" $1996-$ http://www.rdg.opengroup.org/public/tech/security/sso/sso_intro. htm

(XOC 1996b) X/Open Company Limited - "Scope of the Single Sign-On Standard" $-1996-$ http://www.rdg.opengroup.org/public/tech/security/sso/sso_scop e.htm

(Wayner 1995) Wayner, P.: "Picking the Crypto Lock" - Byte - pp 77,80 - Oct. 1995

(Zamboni et al. Zamboni, D.; Spafford, E.; Isacoff, D.; Garcia-Fernandez, J.O.; 1998) Balasubramaniyan, J.S.: "An Architecture for Intrusion Detection using Autonomous Agents" - 1998 - Relatório Técnico COAST $98 / 05$ 


\section{4.}




\section{APÊNDICE - A}

\section{Normas para uso dos Laboratórios de Informática do ICMC-USP}

Estas Normas complementam e detalhamos princípios éticos estabelecidos pela Portaria GR-3082, de 06/10/1997.

\section{Uso das Instalações}

- Entende-se que os Laboratórios do ICMC-USP são de propriedade pública. Assim, como regra geral, o uso dos Laboratórios deve ser condizente com as normas estabelecidas para o uso dos mesmos e respeitar os padrões de segurança estabelecidos, tal que os interesses da coletividade local e da USP prevaleçam sobre os individuais.

- O uso das instalações dos Laboratórios de Informática do ICMC-USP está sujeito às regras estabelecidas pela Comissão de Informática do ICMC-USP.

- O uso indevido das instalações (prédio e equipamentos) estará sujeito às penalidades previstas no item III.

- Constitui uso indevido:

- Praticar atividades que afetem ou coloquem em risco as instalações (ex. roubo, incêndio, inundaçăo, etc.), bem como atividades ou práticas que promovam o desperdício de recursos, de energia, de água, etc;

- Facilitar o acesso aos Laboratórios de pessoas estranhas ao ICMC-USP e/ou pessoas năo autorizadas (ex. empréstimo de chaves, cópias de chaves, abertura de portas, etc.);

- Exercer atividades que coloquem em risco a integridade física das instalações e/ou equipamentos dos Laboratórios (ex. comer, beber, fumar, etc.);

- Perturbar o ambiente com brincadeiras, algazarras e/ou qualquer outra atividade alheia às atividades do Instituto;

- Desmontar quaisquer equipamentos ou acessórios do Laboratório, sob qualquer pretexto, assim como remover equipamentos do local a eles destinado (mesmo dentro do recinto);

- Usar qualquer equipamento de forma danosa ou agressiva ao mesmo;

- Exercer atividades não relacionadas com o uso específico de cada Laboratório; 
- Usar as instalações do ICMC-USP para atividades eticamente impróprias, conforma estabelecido no item $\mathrm{ll}$;

- Usar abusiva e indevidamente o material de consumo disponível (ex. papel, toner, tinta).

II. Uso Ético dos Laboratórios e Equipamentos

- Constitui uma falta, passível de penalidade conforme previsto no item III:

- Alterar a configuração de qualquer equipamento disponivel;

- Instalar ou remover programas/software, a menos que autorizado e devidamente assistido por um técnico do Laboratório;

- Desenvolver e/ou disseminar vírus nos equipamentos do Laboratório;

- Praticar ou facilitar a prática de pirataria de software/dados de qualquer espécie;

- Praticar intrusão de qualquer espécie, tal como quebrar privacidade, utilizar a conta alheia, tentar quebrar sigilo e/ou senha, ganhar acesso de super-usuário, obter senhas de outros usuários, causar prejuizo de operação do sistema em detrimento dos demais usuários, utilizar programas para burlar o sistema, bloquear as ferramentas de auditoria automática e/ou outras ações semelhantes;

- Usar indevidamente os recursos disponíveis na Internet;

- Praticar, de maneira não autorizada, ou facilitar a prática de qualquer atividade alheia aos interesses da Universidade (ensino, pesquisa e extensão de serviços à comunidade);

- Divulgar coletivamente, pela rede, mensagens de interesse particular ou reduzido. Mensagens com conteúdo que pode ser considerado indecoroso, ofensivo ou pretensamente humoristico devem ser evitadas;

- Facilitar a divulgação das listas do ICMC-USP para fins comerciais e/ou para qualquer outro fim exterior ao conteúdo universitário;

- Utilizar o sistema de correio eletrônico para fins comerciais pessoais.

III. Penalidades

Além do que é previsto pela legislação em vigor e pelo Regimento Geral da Universidade de São Paulo, segundo a Portaria GR 3082 de 06/10/1997, o não cumprimento das normas acima estabelecidas acarretará em penalidades estipuladas e 
impostas pela Comissão de Informática ou pela direção do ICMC-USP, conforme sua gravidade, podendo implicar em:

- Advertência oral e/ou escrita;

- Suspensão e/ou encerramento de conta do usuário;

- Proibição de acesso às instalações do ICMC-USP, temporária ou definitiva;

- Responsabilidades civis ou pessoais cabiveis dentro da lei;

- Aplicaçōes do Regimento Geral da USP para as penalidades acadêmicas previstas pela Universidade;

- Publicação no ICMC-USP das ocorrências.

IV. Disposições Gerais

Os casos nāo cobertos detalhadamente por estas Normas, deverão ser apreciados pela Comissão de Informática, ou por uma Comissão por ela indicada para esse fim. 


\section{APÊNDICE - B}

\section{[ REGULAMENTO GERAL PARA USO E ADMINISTRAÇÃO DE COMPUTADORES E REDES DA UNESP ]}

Referência: RG-AI.00.01.01

Data: 07/01/1998

\section{INTRODUÇÃO}

Este documento pretende levar em consideração o uso apropriado dos recursos de computação e redes, a proteção e a privacidade efetiva aos usuários, e a própria administração desses recursos na UNESP. Estas regras visam a complementar e não substituir leis já existentes que se apliquem a estes serviços.

As Unidades Universitárias, Núcleos e Centros de Pesquisa, Fundações Associadas, Departamentos, Laboratórios, Diretorias, Seções, Setores e congêneres - doravante denominados genericamente de "Unidades" - da UNESP, que operam seus próprios computadores e redes podem acrescentar, com a autorização do Diretor da Unidade ou de seu órgão assessor (Comissão Local de Informática - CLI), regras próprias para complementar este regulamento, sem a intenção de abrandá-lo. Qualquer ato no sentido de suplantar ou desautorizar este regulamento será considerado sem efeito.

\subsection{Fundamento Principal}

O uso de computadores e redes deve estar reiacionado ao ensino, ao estudo independente, à pesquisa autorizada, à pesquisa independente, ao acesso e à disseminação de informações de interesse da UNESP, e ao trabalho das Unidades.

\section{DEFINIÇÕES}

\section{1. Autorização de uso:}

Autoriza-se o uso dos recursos de computação e de redes pertencentes à UNESP, ou operados pela mesma, para fins de educação, pesquisa, prestação de serviços e outras atividades que estiverem de acordo com os regulamentos desta Universidade.

\subsection{Usuários autorizados}

São considerados usuários autorizados dos sistemas de computação da UNESP: corpo docente, servidores técnicos e administrativos e alunos em situação regular junto às Unidades. As Unidades podem ceder autorizaçðes especiais de uso ou acesso, por tempo determinado, desde que esta 
utilização esteja de acordo com o item I. I acima.

\section{RESPONSABILIDADES INDIVIDUAIS}

\subsection{Acesso a informações}

Nenhum usuário pode ter acesso, copiar, alterar ou remover arquivos de terceiros sem autorização explícita, ressalvados casos especiais protegidos por lei ou regulamento.

\subsection{Propriedade intelectual}

Todos os usuários têm o dever de reconhecer e honrar a propriedade intelectual e os direitos autorais.

\subsection{Molestamento}

Nenhum membro da comunidade de usuários pode, sob quaisquer circunstâncias, usar computadores e redes da UNESP para difamar, caluniar ou molestar outras pessoas.

\subsubsection{Situações de molestamento}

Entende-se por molestamento o uso intencional dos computadores ou redes para:

Perturbar, amedrontar, ameaçar ou ofender pessoas usando linguagem ou qualquer outro mecanismo ou material para fazer ameaças que comprometam a integridade física ou moral do receptor ou de sua família;

Contatar alguém várias vezes com a intenção de perturbá-la, enviando ou não mensagens, seja quando não existe uma proposta de comunicação ou quando o receptor expressa o desejo de finalizar a comunicação;

Indisponibilizar recursos computacionais de forma intencional;

Causar danos ou prejudicar as pesquisas ou a administração acadêmica;

Invadir a privacidade da Unidade, da UNESP ou de outros.

\subsection{Responsabilidade no uso dos recursos}

Os usuários devem estar cientes das regras e normas de uso dos recursos de informática (que podem ser setoriais), evitando, desse modo, os procedimentos que prejudicam ou impedem outras pessoas de terem acesso a esses recursos ou de usá-los de acordo com o que é determinado. Os usuários não podem, deliberadamente, sobrecarregar os recursos computacionais ou de rede. 


\subsection{A Integridade e confrabilidade das informaçø̌es}

É dever do usuário estar ciente do potencial e das possiveis conseqüências da manipulação de informaçóes, especialmente em forma eletrơnica, e assim entender a natureza mutante de informaçóes armazenadas eletronicamente, além de verificar a integridade e a completitude das informaçðes que acessa ou usa. $O$ usuário não deve confiar em informações que contrariem suas expectativas, sem antes verificá-las diretamente junto ao possivel remetente da mensagem, do arquivo ou de qualquer tipo de dado.

\subsection{O uso de sistemas}

O usuário é responsável pela segurança e integridade das informaçōes da UNESP armazenadas nos computadores sob sua responsabilidade. Essa responsabilidade inclui proceder regularmente cópias de segurança de seus dados, controlar o acesso à rede, às suas senhas e às máquinas sob seu uso, e usar programas de proteção contra víns. Deve-se evitar armazenar senhas ou outras informaçōes que possam ser usadas para o acesso a recursos de computação da Unidade.

\subsection{Acesso às instalações e informaçð̃es}

\subsubsection{Proibição de acesso compartilhado}

O usuário é inteiramente responsável pelo uso de sua conta de acesso à rede, senha e outros tipos de autorização, que são de uso individual e intransferivel, e não podem ser compartilhados com terceiros. Contas de acesso à rede devem ser individuais e não-compartilhadas, salvo em situações especiais que a Unidade julgar necessárias, e dentro de prazos curtos e pré-determinados.

\subsubsection{Usuários não-autorizados}

Não é permitido executar ou configurar software ou hardware com a intenção de facilitar o acesso a usuários não-autorizados.

\subsubsection{Obrigatoriedade do uso de senhas seguras}

O usuário é responsável pela manutenção de senhas seguras, devendo seguir normas e procedimentos padronizados e divulgados publicamente pelos órgãos de informática da UNESP. O usuário é totalmente responsável por açőes indevidas que venham a ser efetuadas a partir de sua conta de acesso à rede, caso alguém obtenha o acesso à sua conta devido à não utilização de senhas seguras.

3.7.4. Uso de acesso privilegiado pelos administradores dos sistemas

O acesso especial a senhas, informaçōes ou outros privilégios só pode ser usado para o exercício de tarefas oficiais. Informações obtidas por meio de 
direitos especiais e privilégios devem ser tratadas como privativas e totalmente confidenciais pelos administradores, que responderão por qualquer uso indevido.

\subsubsection{Cancelamento do acesso}

Ao deixar de ser membro da comunidade da UNESP (graduar-se, terminar suas atividades ou demitir-se), ou ao ser nomeado para assumir uma nova função e/ou novas responsabilidades para com a UNESP, o usuário deverá ter sua autorizaçăo de acesso revista e não poderá fazer uso de beneficios, contas, senhas de acesso, direitos especiais ou informações aos quais não está autorizado em sua nova situaçăo. Privilégios especiais não são incorporados permanentemente aos direitos dos usuários.

\subsubsection{Acesso de computadores à rede}

Computadores mono e multiusuário e servidores de rede ou similares, de qualquer espécie, não podem ser conectados à rede de computadores da Unidade ou da UNESP sem notificação e autorização dos administradores, assim como dos supervisores responsáveis pela rede na Unidade. Todos os computadores conectados devem obedecer os procedimentos padronizados de segurança estabelecidos pela Unidade ou por órgãos superiores da UNESP e devem seguir este regulamento. Deve ser facultado acesso dos administradores a todos os equipamentos ligados à rede, de forma a ser possivel a realização de procedimentos de auditoria, controle e segurança que se fizerem necessários.

\subsection{Autorização de uso de mecanismos de auditoria e segurança}

Os responsáveis pela administração dos sistemas possuem autorização para utilizar o sistema de segurança ou qualquer mecanismo que julgarem mais adequado para a realização de auditoria e o controle dos computadores e redes.

\subsection{Acessos, operaçø̃es e ações proibidas aos usuários}

\subsubsection{Decodificação e acesso ao controle de informaçðes}

Os Usuários não podem utilizar qualquer software ou outro dispositivo para interceptar ou decodificar senhas ou similares.

\subsubsection{Atividades perniciosas}

É proibida toda e qualquer tentativa deliberada de retirar o acesso à rede ou a qualquer computador da UNESP, ou de prejudicar o seu rendimento. Procedimentos considerados graves:

Criar ou propagar víns, danificar serviços e arquivos;

Destruir ou estragar intencionalmente equipamentos, software ou dados pertencentes à UNESP ou a outros usuários; 
Obter acesso a qualquer recurso não-autorizado;

Destituir os direitos de outros usuários;

Obter acesso năo-autorizado aos sistemas.

As ações acima são proibidas mesmo com o uso dos seguintes expedientes:

Senhas especiais obtidas por quaisquer meios;

Falhas nos sistemas de segurança dos computadores e redes;

Senhas de terceiros obtidas por quaisquer meios;

Direitos especiais de acesso já extintos com o término do período de ocupação de cargo ou funçĩo na UNESP.

\subsubsection{Monitoramento não-autorizado}

Os recursos de computação não podem ser utilizados para o monitoramento não-autorizado de mensagens eletrônicas ou de qualquer transmissấo de dados.

3.9.4. Uso de informações e materiais protegidos por copyright

Não é permitido ao usuário servir-se dos recursos de informática da UNESP para usar, examinar, copiar ou armazenar qualquer material protegido por copyright, sem que possua licença ou autorização específica para tal.

\subsubsection{Propagandas e campanhas politicas}

É proibido o uso de computadores e redes da UNESP em campanhas políticas ou propaganda de qualquer espécie. A veiculação de nomes de empresas, instituições ou pessoas junto aos sistemas de informação da UNESP só poderá ser realizada se houver o estabelecimento oficial e reconhecido de convênios de cooperação ou parceria acadêmica, técnica ou cientifica.

\subsubsection{Uso dos recursos da UNESP em atividades particulares}

Computadores, redes e outros serviços de informática não podem ser usados para trabalhos particulares, ou em beneficio de organizaçōes que não tenham relação com a UNESP e em acordo com o item 1. I. acima.

\subsubsection{Uso excessivo}

O uso individual dos recursos computacionais, tais como mensagens eletrónicas, acesso à Internet, o armazenamento de dados em computadores ou a impressão de arquivos, não devem ser excessivos nem interferir na utilização e acesso a outros usuários a estes recursos.

\subsubsection{Inatividade do acesso à conta}


O tempo máximo de inatividade de uma conta é de 6 meses. O usuário será avisado após 4 meses de inatividade da conta e quando da extinção da mesma. Cabe ao Administrador de Rede Local providenciar mecanismos para esse controle.

\section{PRIVILÉGIOS DAS UNIDADES}

\subsection{Controle do acesso a informaçðes}

As Unidades devem controlar o acesso a suas informaçðes e a suas formas de armazenamento, a manipulação e a transmissão de acordo com as normas superiores da UNESP, de conformidade com as leis estaduais e federais.

\subsection{Imposiç̃o de sançð̃es}

As Unidades devem impor sanções e penas aos que violarem este regulamento.

\subsection{Acesso de supervisores e administradores ao sistema}

O supervisor ou administrador (responsável pelas operações técnicas de determinada máquina ou rede) pode ter acesso a arquivos de outros usuários para garantir a segurança, manutenção e conservação de redes, computadores e sistemas armazenados. No entanto, todos os privilégios individuais e direitos de privacidade dos usuários deverão ser preservados.

\subsection{Monitoramento de uso, inspeção de arquivos e auditoria}

As Unidades da UNESP responsáveis pelas operações de informática que, freqüentemente, operam computadores e redes podem monitorar e registrar dados como início e fim de conexão à rede, tempo de CPU, utilização de discos feita por cada usuário, registros de auditoria, carga de rede, dentre outros. Os supervisores ou administradores responsáveis pelas redes e recursos computacionais devem rever e observar periodicamente essas informaçđ̃es, certificando-se de que não houve a violação de leis nem de regulamentos, ou para outros fins.

Se houver evidência de atividade que possa comprometer a segurança da rede ou dos computadores, estes supervisores podem monitorar todas as atividades de um determinado usuário, além de inspecionar seus arquivos nos computadores e redes, a bem do interesse da UNESP. As açoes de auditoria são restritas aos supervisores responsáveis pelo gerenciamento da rede em questão. O supervisor que acreditar que tal monitoramento ou inspeção é necessária, deve notificar seu superior imediato para realizar esta operação. Ao utilizar os recursos de informática da UNESP, 0 usuário concorda com esta norma e autoriza implicitamente as ações de auditoria eventualmente necessárias.

\subsection{Suspensão de privilégios individuais}


As Unidades podem suspender todos os privilégios de determinado usuário em relaça ao uso de redes e computadores sob sua responsabilidade, por razð̃es ligadas à segurança física e ao bem estar do usuário, ou por razões disciplinares ou relacionadas à segurança e ao bem-estar dos outros membros da Unidade ou da UNESP.

\subsubsection{Possibilidade de novo acesso}

O acesso será prontamente restabelecido quando a seguranca e o bem-estar puderem ser assegurados; a suspensão do acesso pode contimuar se for resultado de uma ação disciplinar imposta pelos órgãos assessores da Unidade ou instâncias superiores.

\section{RESPONSABILIDADES DAS UNIDADES}

\subsection{Medidas de segurança}

A Unidade e seus órgãos encarregados da administração dos recursos computacionais são responsáveis pelas medidas de segurança necessárias para garantir a integridade de informaç̋es relativas à Unidade e a cada usúrio, independentemente da maneira pela qual estejam armazenadas, $\mathrm{e}$ impor as penalidades cabíveis quando qualquer norma for desrespeitada.

\subsection{Defesa de direitos autorais e de licenças}

A Unidade defenderá os direitos autorais (copyright), as leis que regulamentam o acesso e o uso de informaçðes e as regras de organizações que fornecem informações aos membros da comunidade (por exemplo, regras ou procedimentos para o uso da Intemet ou outras redes).

\subsection{Deveres de cada Unidade}

Cabe a cada Unidade a responsabilidade de:

Assegurar o cumprimento deste regulamento;

Manter fichas cadastrais com os dados de todos os usuários autorizados, inclusive com a assinatura do termo de compromisso ratificando o conhecimento e a concordância deste e de outros regulamentos, conforme modelo no anexo I;

Manter, na Unidade, um registro das ocorrências de violação dos regulamentos;

Garantir a segurança de suas áreas;

Controlar o acesso físico aos equipamentos sob sua responsabilidade;

Não permitir que softwares licenciados para uso da UNESP sejam copiados por 
terceiros ou instalados em computadores não autorizados.

Por responder pela importância e a sensibilidade das informações armazenadas e processadas em suas instalaçð̃es, o setor responsável pelos recursos de informática da Unidade (Pólo Computacional ou similar) e seus administradores, gerentes ou coordenadores terão a responsabilidade de :

Designar funcionários para administração dos sistemas;

Fazer cópias de segurança e verificar sua integridade;

Adotar medidas apropriadas de segurança em relação a software e rotinas;

Preservar informaçðes confidenciais como, por exemplo, arquivos de usuário e códigos de acesso ao sistema;

Administrar devidamente o acesso, regularizar de maneira rápida e precisa as permissões de acesso para usúrios transferidos ou que tiveram seu acesso cancelado (ver item 3.7.5);

Controlar, gravar software e mudar de configuração os sistemas de rede e similares;

Monitorar os logins, acessos e registros de auditoria dos sistemas para controlar tentativas de violação e quebra de segurança;

Manter as conexões e o roteamento de transmissão de dados em funcionamento;

Respeitar e seguir os procedimentos padronizados para a administração de recursos de informática e redes definidos pelos órgãos superiores da UNESP.

\subsection{Serviços de informação ao público}

As Unidades e seus responsáveis podem, com pernissẫo do Diretor ou de seu órgão assessor, configurar sistemas para fornecer serviços de busca de informaç̋es à comunidade externa (os exemplos atuais incluem serviços de "anonymous ftp", "listservers" e "WWW").

\subsubsection{Sobrecarga}

A extensão desses serviços ao público não poderá provocar sobrecarga nos computadores e redes, prejudicando assim outros serviços, e respeitará incondicionalmente este regulamento.

\section{PROCEDIMENTOS E SANÇÕES}

\subsection{Conhecimento e concordância deste regulamento}

Todo interessado, ao se cadastrar como usuário de recursos de informática 
da UNESP, deve preencher e assinar uma ficha cadastral e um termo de compromisso elaborado pela Unidade, o qual manifesta conhecimento e concordância, comprometendo-se a respeitar este regulamento e as normas especificas de uso e acesso de cada Unidade (vide anexo I). Esta ficha cadastral deverá ser mantida sob o controle da Unidade em caráter confidencial e as informações presentes não poderão ser utilizadas para qualquer finalidade não relacionada ao controle, à segurança e à integridade dos sistemas.

\subsection{Respondendo pela segurança $e$ incidentes}

Todos os usuários e administradores têm o dever de denunciar qualquer tentativa de acesso não-autorizado ou qualquer outro uso indevido de computadores e redes da UNESP. Ao testemurhar ou tomar conhecimento (por quaisquer meios) de problemas rclacionados à seguranç ou ao uso abusivo de computadores e redes, incluindo o desrespeito a este regulamento, o usuário deve tomar imediatamente as providências necessárias que estiverem a seu alcance, para garantir a segurança e a conservação dos recursos e notificar as seguintes pessoas:

O administrador ou coordenador do sistema em questão;

Seu chefe imediato ou o presidente da Comissão Local de Informática.

\subsection{Incidentes e suas conseqüências}

O primeiro incidente, considerado não grave, envolvendo um usuário será julgado em nível de Unidade pela CLI, a qual deverá impor as sançð̃es cabiveis, com posterior registro da ocorrência.

Reincidências e incidentes considerados graves deverão ser tratados pela CLI, a qual encaminhará o caso ao Diretor da Unidade, para determinação das sanções a serem impostas, com posterior registro da ocorrência.

\subsection{Penalidades a serem aplicadas}

\subsubsection{Penalidades nivel I (não grave)}

A violação das normas descritas referente aos itens 3.6 e 3.9 .5 resultará na suspensão temporária de privilégios de acesso por, no mínimo, 7 dias e, no máximo, 3 meses.

\subsubsection{Penalidades nível II (intermediário)}

A violação das normas descritas referente aos itens $3.1,3.2,3.4,3.7 .1$, 3.7.3, 3.9.4 e 3.9.6 resultará na suspensão temporária de privilégios de acesso por, no minimo, 7 dias e, no máximo, 6 meses.

\subsubsection{Penalidades nível III (grave e reincidências)}

A violação das normas descritas referente aos itens $3.3,3.7 .2,3.7 .4,3.7 .5$, 3.7.6, 3.9.1, 3.9.2 e 3.9.3 resultará na suspensão temporária de privilégios de acesso por, no mínimo, 30 dias e, no máximo, 1 ano. 


\title{
6.4.4. Outras situaçð̃es
}

Todas as demais violaçðes das normas, ainda que não expressamente descritas, serão punidas com suspensão temporária ou permanente de privilégios de acesso aos recursos computacionais, após avaliação da gravidade da infração.

Qualquer que seja o tipo de infração, dependendo de sua gravidade, as penalidades aqui fixadas poderão ser substituídas pela penalidade de suspensão permanente de privilégios de acesso aos recursos computacionais.

Caso as infrações às normas de segurança impliquem também em falta disciplinar, o assunto será objeto de apuração e solução mediante a aplicação das normas já existentes na Universidade de acordo com o Regimento Geral da UNESP.

\subsection{A extensão das sançōes disciplinares}

Os alunos e servidores da UNESP que desrespeitarem este regulamento, além das sancōes anteriormente descritas, estão sujeitos a ações disciplinares ou demissão a bem do serviço público. As saņ̧oes impostas pela Ưnidade não isentam o responsável de outras ações legais. Os incidentes envolvendo telecomunicações ou transmissão de dados que forem considerados crimes, de acordo com as leis estaduais ou federais, deverão ser denunciados pela Unidade às autoridades competentes.

O possivel desconhecimento desse regulamento por parte do usuário não o isenta das responsabilidades e das sançōes aplicáveis, nem pode minimizar as medidas cabiveis.

\section{CASOS OMISSOS A ESTE REGULAMENTO}

Casos omissos a este regulamento serão tratados pela Comissão Local de Informática e pelo Diretor da Unidade, cabendo recurso à Comissão de Informática da Reitoria.

\author{
São Paulo, 07 de janeiro de 1998 \\ UNESP - Reitoria \\ Assessoria de Informática
}

\begin{abstract}
ANEXO I
MODELO DE FICHA DE CADASTRO PARA USO DE RECURSOS COMPUTACIONAIS E ACESSO Ȧ REDE DE COMPUTADORES
\end{abstract}

(Pode ser adaptada para atender necessidades e exigências locais)

Nome 
Vínculo com a UNESP:

( )Servidor ( )Aluno ( )Outros

Unidade - Órgão

Documento de Identificação (R.G. ou passaporte)

Endereço completo

Telefone res./com.

Máquina - Domínio

Nome da conta (username)

Data do término da validade (definida pelo responsável pela autorização da conta)

\section{TERMO DE COMPROMISSO}

Declaro ser responsável pela conta acima solicitada, sendo conhecedor(a) das determinaç̃̃es contidas no Regulamento Geral para Uso e Administração de Computadores e Redes da UNESP (http://intranet.unesp.br/ai/regulamentos). Comprometo-me a respeitar as normas da Universidade relativas ao assunto, assumindo as consequiências administrativas, cíveis e penais decorrentes do desvio de finalidade e do desrespeito às normas de uso de contas. Comprometo-me, ainda, a aceitar eventuais alterações e regulamentaçōes futuras, assim como de comunicar meu desligamento da Universidade, a qualquer titulo, para a regularização da conta.

Por ser verdade, firmo a presente.

\section{Usuário}

Local ___ I__




\section{APÊNDICE - C}

PORTARIA GR N 065/97, 22/05/97 - (Repositório da PROCURADORIA GERAL)

Reitor: José Martins Filho.

Estabelece a Politica de Uso dos Recursos Computacionais.

O Reitor da Universidade Estadual de Campinas, no uso de suas atribuições legais, baixa a seguinte Portaria:

Artigo $1^{\circ}$ - Esta Portaria estabelece a Política de Uso dos Recursos Computacionais da UNICAMP.

Parágrafo Único - Para os fins desta Portaria, considera-se:

I - A Coordenadoria Geral de Informática (CGI), nos termos da Portaria GR 44/94, como a responsável pela gestão dos Sistemas de Informação e dos Recursos

Computacionais de Processamento e de Transmissão de Dados da Universidade.

II - Recursos Computacionais da Universidade Estadual de Campinas são os equipamentos, as instalaçōes ou bancos de dados direta ou indiretamente

administrados, mantidos ou operados pelo Centro de Conıputaçăo ou pelas Unidades de Ensino e Pesquisa, Centros, Núcleos e Órgãos Administrativos, tais como:

- computadores e terminais de qualquer espécie;

- impressoras;

- redes;

- bancos de moldem e equipamentos afins;

- bancos de dados ou documentos residentes em disco, fita ou outros meios;

- salas de computadores, laboratórios, escritórios e mobiliário.

III - Usuário é qualquer pessoa, autorizada ou não, que utiliza, de qualquer forma, algum recurso computacional da UNICAMP, incluindo pessoas, fisicas ou jurídicas, que acessam os recursos via uma rede eletrônica ou em salas de computadores da UNICAMP e aquelas que utilizam qualquer rede da UNICAMP para conectar uma máquina pessoal e qualquer outro sistema ou serviço.

Artigo $2^{\circ}$ - Os Recursos Computacionais da UNICAMP têm por finalidade servir à Pesquisa, ao Ensino e às Atividades Administrativas da Universidade e se

destinam a seus professores, alunos e funcionários da Universidade.

$\S 1^{\circ}$ - Instituições e pessoas não vinculadas à Universidade poderão ter autorização para se utilizar dos Recursos Computacionais da UNICAMP, respeitadas as

Normas de Uso baixadas especificamente para esse fim pela Comissăo Diretora de Informática (CDI) e periodicamente atualizadas, tendo em visto os interesses da Universidade.

$\S 2^{\circ}$ - A permissão de acessos, a partir de pontos externos à Universidade, como, por exemplo, correio eletrônico em chegada, servidor POP, FTP anônimo ou serviços similares, será regulamentada pelas Normas de Uso baixadas pela CDI.

Artigo $3^{\circ}$ - Constituem responsabilidades do Usuário relativamente ao uso dos Recursos Computacionais da UNICAMP: 
I - Autorização Apropriada - para utilizar qualquer Recurso Computacional da UNICAMP o Usuário deve antes obter uma autorização por escrito e assinar o

Termo de Responsabilidade, no qual declara conhecer as normas em vigor e se compromete a cumpri-las;

II - Responsabilidade pela Conta - Toda conta é de responsabilidade e de uso exclusivos de seu titular, não podendo esse permitir ou colaborar com o acesso aos

Recursos Computacionais da UNICAMP por parte de pessoas não autorizadas. Os Usuários são responsáveis por qualquer atividade desenvolvida através de suas

contas na UNICAMP e pelos eventuais custos dela decorrentes.

III - Identificação Pessoal - Os Usuários dos Recursos Computacionais da UNICAMP devem mostrar carteira funcional ou carteira estudantil da UNICAMP ou

autorização especial ao pessoal responsável sempre que for solicitado durante a utilização dos Recursos, sob pena de imediata suspensão da conexão;

IV - Acesso a Dados - Nos Recursos Computacionais da UNICAMP, será garantido o maior grau possível de confidenciabilidade no tratamento dos dados dos

Usuários, de acordo com as tecnologias disponiveis. Entretanto, o Grupo de Segurança do CCUEC e os

administradores de redes em suas Unidades poderão

acessar arquivos de dados pessoais ou corporativos nos sitemas da UNICAMP sempre que isso for necessário para backups ou diagnóstico de problemas nos

sistemas, inclusive nos casos de suspeita de violação de regras;

V - Alteraçăo de dados ou de equipamentos - Os usuários, a menos que tenham uma autorização específica para esse fim, não podem tentar, permitir ou causar

qualquer alteração ou destruição de ambientes operacionais, dados ou equipamentos de processamento ou comunicaçoes instalados na Universidade, de sua

propriedade ou de qualquer outra pessoa ou instituição. Essas alteraçōes incluem, mas não se limitam, a alteração de dados, reconfiguração de chaves de controle ou parâmetros, ou mudanças no firmware.

VI - Prejuizos a terceiros - Os recursos computacionais da UNICAMP não podem ser utilizados para constranger, assediar ou ameaçar qualquer pessoa. Esses

recursos não podem ser usados para alterar ou destruir recursos computacionais de outras de outras instituiçð̃es. Se a partir de uma conta, um usuário estiver, de

qualquer maneira, interferindo no trabalho de um outro, este deve comunicar o fato ao responsável pelo equipamento onde está a conta, o qual, a seu critério, e sem

prejuizo de outras sançøes, poderá determinar a imediata suspensão temporária da conta de onde parte a interferência, comunicado o caso d̀ Comissão de

Segurança de Recursos Computacionais;

VII - Correntes de cartas e outras comunicações eletrônicas indesejadas - É proibida a distribuição voluntária ou desapercebida de mensagens não desejadas,

como circulares, correntes de cartas ou outros esquemas que possam prejudicar o trabalho de terceiros, causar excessivo tráfego na rede ou sobrecarregar os

sistemas computacionais;

VIII - Componentes externos - Sem uma autorização específica, os usuários não podem ligar ou desligar fisicamente ou eletricamente a um recurso computacional

da UNICAMP, nenkum componente externo, como cabos, impressoras, discos ou sistemas de vídeo;

IX - Remoção de documentos - Sem uma autorização especifica, os usuários não podem remover dos recursos computacionais da UNICAMP nenhum documento

de propriedade da Universidade ou por ela administrado. 
X - Outros usos - A utilização dos recursos computacionais da UNICAMP para beneficio financeiro direto, próprio ou de terceiros fora da Universidade, deve

obedecer às normas de uso baixadas pela CDI, seguidas as demais normas em vigor na Universidade. É permitida a comunicação normal e a troca de dados

eletrônicos de interesse para o ensino, a pesquisa e a administraçăo, mesmo que isso tenha como

consequência beneficios, financeiros ou não, para entidades

externas à Universidade. São permitidas a contribuição em listas de discussão via rede sobre produtos ou

serviços com companhias que tenham negócios com a

Universidade;

XI - Redes de Dados Externas - Quando utilizarem Redes de Dados Externas, os Usuários devem observar as suas normas e diretrizes;

XII - Direitos Autorais - Os Usuários devem respeitar os direitos de propriedade intelectual, em particular a lei de direitos autorais de softwares;

XIII - Contratos - Todo e qualquer uso dos Recursos Computacionais da UNICAMP deve estar de acordo com todas as obrigaçōes contratuais da Universidade,

inclusive com as limitações definidas nos contratos de software e outras licenças;

XIV - Legislação - O uso de qualquer Recurso Computacional da UNICAMP está sujeito às leis Federais, Estaduais, Municipais, às regulamentações da

Universidade e às nomas para uso da Internet recomendadas pelo Comitê Gestor da Internet Brasil;

XV - Comunicação de Violação - Os Usuários devem comunicar ao Administrador da rede local ou à

Comissão de Segurança de Recursos Computacionais

qualquer evidência de violação das normas em vigor, não podendo acobertar, esconder ou ajudar a esconder violações de terceiros.

Artigo $4^{\circ}$ - Constituem responsabilidades dos Usuários relativamente à Segurança de Uso dos Recursos Computacionais:

I - Os Usuários não podem se fazer passar por outra pessoa ou camuflar sua identidade quando utilizam os Recursos Computacionais da UNICAMP com exceção

dos casos em que o acesso anônimo é explicitamente permitido;

II - Os Usuários não devem, deliberadamente, efetuar ou tentar qualquer tipo de acesso não autorizado a dados dos Recursos Computacionais da UNICAMP, ou

tentar sua alteração, como por exemplo ler mensagens pessoais de terceiros ou acessar arquivos confidenciais da Universidade;

III - Os Usuários não podem violar ou tentar violar os sistemas de segurança dos Recursos Computacionais da UNICAMP, como quebrar ou tentar advinhar

identificaçăo ou senhas de terceiros, interferir em fechaduras automáticas ou sistemas de alarme;

IV - Os Usuários não podem interceptar ou tentar interceptar transmissão de dados não destinados ao seu próprio acesso, seja monitorando barramentos de dados

seja através da rede, exceto quando autorizado explicitamente pelo Diretor da Unidade para a rede local ou pelo Superintendente do Centro de Computação para

a rede corporativa;

V - Os Usuários não podem tentar ou efetuar a interferència em serviços (jobs) de outros Usuários ou o seu bloqueio, provocando, por exemplo, congestionamento da rede, inserindo víns ou tentando a apropriação de recursos dos Recursos Computacionais da UNICAMP. 
VI - Os Usuários são responsáveis pela segurança de suas contas e de suas senhas. A conta e a respectiva senha são atribuídas a um único usuário e não devem ser compartilhadas com mais pessoas sem a autorização expressa da CGI. Os Usuários devem relatar imediatamente à Comissão de Segurança de Recursos

Computacionais qualquer suspeita de tentativa de violação de segurança.

Artigo $5^{\circ}$ - Para garantir a adequada utilização dos Recursos Computacionais da UNICAMP, a Comissão Diretora de Informática fica autorizada a aplicar penalidades aos que violarem a legislação em vigor e as dispostas nesta Portaria.

$\S 1^{\circ}$ - As penalidades a serem aplicadas por infraça às normas indicadas no "caput", são redução ou eliminação, temporárias ou permanentes, de privilégios de acesso, tanto aos Recursos Computacionais, quanto às redes, salas de computadores da UNICAMP e outros serviços ou facilidades.

$\S 2^{\circ}$ - Qualquer violaçáo ou suspeita de violação dessas regras deve ser comunicada imediatamente ao responsável direto pelo recurso computacional no local onde

o fato tenha ocorrido. Em caso de dúvida, o fato deve ser comunicado à Comissão de Segurança de Recursos Computacionais.

$\S 3^{\circ}$ - Sempre que julgar necessário para a preservaçăo da integridade dos Recursos Computacionais da UNICAMP, dos serviços aos usuários ou dos dados, a

Comissão de Segurança de Recursos Computacionais poderá suspender temporariamente qualquer conta, seja ou não o responsável pela conta suspeito de alguma violação.

$\$ 4^{\circ}$ - O Usuário suspeito de violação dessas normas será notificado da acusação e terá oportunidade de se pronunciar antes da decisão da pena pela Comissâo

Diretora de Informática. Após receber a pena, o usuário poderá apelar à CGI.

$\S 5^{\circ}$ - Se, a critério da Comissão Diretora de Informática, a violação merecer alguma penalidade além das aqui determinadas, o caso será apurado mediante a

instauração do processo administrativo ou disciplinar competente.

Artigo $6^{\circ}$ - Com essas normas a UNICAMP não renuncia a nenhuma pendência que possa ter quanto à propriedade ou controle de quaisquer software e hardware

e dos dados criados ou armazenados em seus sistemas ou transmitidos através de sua rede.

Artigo $7^{\circ}$ - Esta Portaria entrará em vigor na data de sua publicação, revogadas as disposições em contrário.

\section{PORTARIA GR N ${ }^{\circ}$ 17/98, DE 23/01/98. - (Repositório da PROCURADORIA GERAL)}

Dispõe sobre normas de uso e segurança dos recursos computacionais da Universidade Estadual de Campinas.

O Reitor da Universidade Estadual de Campinas, no uso de suas atribuiç̃es, e considerando o disposto nas Portaria GR 65, 66 e 67 de 1997, baixa a seguinte

PORTARIA:

Artigo $1^{\circ}$ - Ficam estabelecidas as seguintes normas de uso e segurança dos recursos computacionais da Universidade Estadual de Campinas.

Capitulo I - DA ADMINISTRAÇÃO 
Artigo $2^{\circ}$ - Cada rede local da Universidade deve ter um Administrador de Rede Local titular e um suplente. Compete ao Administrador de Rede Local:

I - Administrar e manter a rede local de acordo com os procedimentos definidos no guia do Administrador de Rede Local elaborado pela Comissão de Redes da UNICAMP, criada pela Portaria GR 67/97;

II - Realizar a abertura, controle e fechamento de contas de acordo com o estabelecido na presente portaria;

III - Responsabilizar-se por outras tarefas inerentes à sua função que forem eventualmente determinadas pela direção da Unidade ou Orgão que possui a rede local.

\section{Capitulo II - DAS CONTAS}

Artigo $3^{\circ}$ - Para garantir a segurança da Rede da Universidade e para facilitar às Unidades e Órgãos o controle das contas de seus usuários nas máquinas corporativas, na sua própria rede local ou em outras redes locais, será criado e mantido pelo Centro de Computação um Sistema Unificado com Banco de Dados único, contendo informações cadastrais de todas as contas existentes na Universidade, seja em máquinas corporativas, seja em redes locais.

$\S 1^{\circ}$ - O Sistema Unificado será alimentado automaticamente cada vez que uma conta for aberta.

$\S 2^{\circ}$ - O Sistema Unificado disponibilizará on-line:

a) emissão de Termo de Identificação e Compromisso definidos no Anexo I da presente Portaria;

b) informações atualizadas aos Responsáveis por contas;

c) informaçøes ao Administrador de Rede Local sobre todas as contas dos usuários de sua Unidade ou Órgâo.

Artigo $4^{\circ}$ - A solicitação de abertura de contas tanto em máquinas locais como em máquinas corporativas se dá pelo preenchimento do Termo de Identificação e

Compromisso, o qual deve ser assinado pelo solicitante e pelo seu Responsável.

$\S 1^{\circ}$ - Para solicitante com vínculo empregatício com a Universidade ou Professores Convidados, nos termos das Deliberaçōes CONSU A-35/91 e A-04/92, o

Responsável é o seu chefe imediato.

$\$ 2^{\circ}$ - Para alunos matriculados em disciplinas e, ou, curso da Universidade, o Responsável é o Coordenador do Curso, ou o orientador no caso de alunos com

projetos de pesquisa.

$\$ 3^{\circ}$ - Para os demais solicitantes, como os descritos abaixo, a responsabilidade fica assim definida:

a) pesquisadores visitantes e pós-doutorandos, terão como Responsável o professor que os convidou ou com o qual eles trabalham diretamente;

b) estagiários sem vínculo empregatício com a Universidade poderão solicitar a abertura de conta, a critério da Unidade. Neste caso, o Responsável é o servidor ao qual suas atividades estão subordinadas;

c) pesquisadores de instituição de ensino e, ou, de pesquisa que mantenham convênios com a Universidade, aprovados pelos órgãos competentes, poderão solicitar a abertura de conta, a critério da Unidade. Nesse caso, do responsável é o pesquisador ou docente executor do convênio na Universidade. 
d) Servidor de empresas, que mantenham convènios com a Universidade, devidamente aprovados pelos órgãos competentes, poderăo solicitar a abertura de conta, a critério da Unidade. Nesse caso o Responsável é o pesquisador ou docente executor do convênio na Universidade.

$\S 4^{\circ}$ - A cada seis meses os Responsáveis receberão informą̧ðes atualizadas sobre as contas pelas quais se responsabilizaram.

$\S 5^{\circ}$ - Para abertura de contas em máquinas corporativas o solicitante deverá justificar porque a conta deverá ser aberta nas mesmas e não em máquina local.

$\S 6^{\circ}$ - Para a abertura de contas em máquinas locais, inclusive para alunos, a Unidade ou Órgão responsável poderá definir normas adicionais, além das aqui previstas.

$\$ 7^{\circ}$ - Cabe ao Administrador de Rede Local controlar a validade da assinatura do Responsável.

$\$ 8^{\circ}$ - Os Termos de Identificação e Compromisso ficam arquivados nas respectivas Unidades.

Artigo $5^{\circ}$ - O Administrador de Rede Local entrará no Sistema Unificado para formalizar a abertura de conta, fornecendo os dados do Termo de Identificação e Compromisso.

$\S 1^{\circ}$ - O Sistema Unificado comunicará automaticamente a abertura da conta ao Responsável pela sua autorização.

$\$ 2^{\circ}$ - Para garantir a segurança da Rede da Universidade, o Sistema Unificado buscará um único "username" para o usuário, mantendo-o igual em todas as máquinas nas quais ele vier a ter conta.

$\S 3^{\circ}$ - Caso haja alteração de "username", Unidade, Órgão, tipo de usuário ou responsável pela conta, deverá ser cancelada a cota original e ser aberta nova conta.

Artigo $6^{\circ}$ - As senhas das contas nas máquinas corporativas serão trocadas, por razões de segurança, a cada quatro meses pelo Centro de Computação. As novas senhas criptografadas serão enviadas aos Administradores de Redes Locais para serem repassadas aos usuários.

$\S 1^{\circ}$ - As senhas das contas nas redes locais serão trocadas, por razões de segurança, a cada quatro meses, de acordo com mecanismos definidos pela Unidade ou Órgão por elas responsável.

$\$ 2^{\circ}$ - O tempo de validade de cada conta fica a critério de cada Unidade ou Órgão, cabendo ao Administrador de Rede Local a responsabilidade do seu controle.

$\$ 3^{\circ}$ - O tempo máximo de inatividade de uma conta é de 6 (seis) meses. O ustário será avisado após quatro meses de inatividade da conta e quando da extinçâo

da mesma. Cabe ao Administrador de Rede Local providenciar mecanismos para esse controle.

$\$ 4^{\circ}$ - Fica a critério de cada Unidade Órgão realizar o recadastramento periódico de suas contas na rede local.

$\S 5^{\circ}$ - A conta será extinta assim que o usuário perder o vinculo com a Universidade.

$\S 6^{\circ}$ - As contas dos usuários definidos no item 4 serão extintas assim que as atividades ali previstas forem encerradas. Cabe aos Responsáveis por essas contas a 
comunicação imediata desse fato ao Administrador de Rede Local.

\section{Capítulo III - DAS PENALIDADES}

Artigo $7^{\circ}$ - Compete ao Administrador de Rede Local verificar a ocorrẻncia das infraçø̃es descritas nesta Portaria e na Portaria GR n ${ }^{\circ} 65 / 97$. Identificada a

ocorrencia o Administrador de Rede Local poderá de imediato adotar as medidas convenientes para evitar sua repetição.

Artigo $8^{\circ}$ - Compete ao Diretor da Unidade ou Responsável pelo Órgão ao qual está vinculado o usuário infrator, ou ao qual ele desenvolve sua atividade, a

aplicação das penalidade abaixo descritas:

$\S 1^{\circ}$ - Utilização indevida de conta, mediante fornecimento de senha a terceiros - suspensão temporária de privilégios de acesso aos recursos computacionais por, no mínimo, 7 dias e, no máximo, 6 meses;

$\S 2^{\circ}$ - Enviar mail com identificação trocada - suspensão temporária de privilégios de acesso aos recursos computacionais por, no minimo, 7 dias e, no máximo, 3

meses;

$\S 3^{\circ}$ - Interferir no funcionamento de equipamentos computacionais essenciais para o funcionamento da rede sem autorizaçāo do Administrador de Rede -

suspensão temporária de privilégios de acesso aos recursos computacionais por, no mínimo, 1 mês e, no máximo, 6 meses;

$\S 4^{\circ}$ - Instalar programas em qualquer equipamento com a finalidade de burlar normas de segurança da rede suspensão temporária de privilégios de acesso aos

recursos computacionais por, no mínimo, 6 meses e, no máximo, 1 ano;

$\S 5^{\circ}$ - Instalar equipamentos não autorizados com o objetivo de quebrar a segurança da rede - suspensão temporária de privilégios de acesso aos recursos

computacionais por, no mínimo, 6 meses e, no máximo, 1 ano.

Artigo $9^{\circ}$ - Todas as demais violações das normas editadas pela Portaria GR $n^{\circ} 65 / 97$, ainda que não expressamente descritas, serão punidas com suspensão

temporária ou permanente de privilégios de acesso aos recursos computacionais, após avaliação da gravidade da infração pela Coordenadoria Geral de Informática

que poderá, a seu critério, solicitar exame ou parecer da Comissão de Segurança de Recursos

Computacionais:

Artigo 10 - A Comissão de Segurança e Recursos Computacionais poderá submeter à Comissão Diretora de Informática, através da Coordena doria Geral de

Informática, sugestão de outras normas de utilização dos recursos computacionais, fixando as penalidades pelas eventuais infrações.

Artigo 11 - Qualquer que seja o tipo de infração, dependendo de sua gravidade, as penalidades aqui fixadas poderão ser substituídas pela penalidade de suspensão permanente de privilégios de acesso aos recursos computacionais.

Artigo 12 - Caso as infraçðes às normas de segurança impliquem também em faita disciplinar, 0 assunto será objeto de apuração e solução mediante a aplicação

das normas já existentes na Universidade de acordo com o Regimento Geral e/ou com o ESUNICAMP.

Artigo 13 - Esta portaria entra em vigor na data de sua publicação, revogadas as disposições em contrário. 
Informação aos Alunos ( janeiro de 1998 )

A Universidade Estadual de Campinas conta com recursos computacionais variados. São aproximadamente 7.000 computadores interligados por

uma rede central (backbone) de fibra óptica com velocidade de $10 \mathrm{Mbps}$, e redes locais nas faculdades, institutos e centros. Existe também um anel

central, com tecnologia ATM, interligando quatro nós a velocidades de 622 e $155 \mathrm{Mbps}$, outro Fast Ethernet a 100Mbps e um FDDI a 200Mbps.

Essa rede da Universidade -UNINet- está ligada à Internet através de dois canais de 2Mbps com a FAPESP em São Paulo, e é o nó de ligação de

diversas entidades de Campinas e região (como PUCCAMP, Prefeitura Municipal, Embrapa, Instituto

Agronómico, CPQD Telebras, etc.). Os 4.000

pontos de rede da Unicamp representam atualmente $5 \%$ da Internet Brasil.

O backbone e os equipamentos centrais săo administrados pelo Centro de Computação e as redes locais são administradas por cada uma das

unidades.

São, até o presente momento, aproximadamente 8.000 contas em computadores e 2.000 contas de acesso externo, nos equipamentos centrais da

Universidade, além das contas nos equipamentos das redes locais.

Informaçōes: Coordenadoria Geral de Informática-CGI http://www.unicamp.br/cgi cgi@turing.unicamp.br tel: (019) 788-7140 - fax: (019) 788-7133

Centro de Computação-CCUEC http://www.ccuec.unicamp.br webmaster@unicamp.br tel: (019) 239-1061

A Informática na Unicamp

A política de informática da UNICAMP está regida pela Portaria GR 65/97, de 22 de maio de 1997, que define. entre outros:

I - A Coordenadoria Geral de Informática (CGI), nos termos da Portaria GR 44/94, como a responsável pela gestão dos Sistemas de Informação e

dos Recursos Computacionais de Processamento e de Transmissão de Dados da Universidade.

II - Recursos Computacionais da Universidade Estadual de Campinas são os equipamentos, as instalações ou bancos de dados direta ou

indiretamente administrados, mantidos ou operados pelo Centro de Computaçăo ou pelas Unidades de Ensino

e Pesquisa, Centros, Núcleos e

Órgås Administrativos, tais como:

- computadores e terminais de qualquer espécie;

- impressoras;

- redes;

- bancos de modem e equipamentos afins;

- bancos de dados ou documentos residentes em disco, fita ou outros meios;

- salas de computadores, laboratórios, escritórios e mobiliário.

III - Usuário é qualquer pessoa, autorizada ou não, que utiliza, de qualquer forma, algum recurso computacional da UNICAMP, incluindo pessoas,

fisicas ou juridicas, que acessam os recursos via uma rede eletrônica ou em salas de computadores da UNICAMP e aquelas que utilizam qualquer 
rede da UNICAMP para conectar uma máquina pessoal e qualquer outro sistema ou serviço.

.....Para utilizar qualquer Recurso Computacional da UNICAMP o Usuário deve antes obter uma autorizaçăo por escrito e assinar o Termo de

Responsabilidade..... Toda conta é de responsabilidade e de uso exclusivos de seu titular, não podendo esse permitir ou colaborar com o acesso

aos Recursos Computacionais da UNICAMP por parte de pessoas não autorizadas.

\section{Abertura de Contas}

Cada rede local da Universidade tem um Administrador de Rede Local titular e um suplente.

Para garantir a segurança da Rede da Universidade e para facilitar às Unidades e Órgãos o controle das contas de seus usuários nas máquinas

corporativas, na sua própria rede local ou em outras redes locais, o Centro de Computaçăo mantêm um Sistema com Banco de Dados único, contendo informaçōes cadastrais de todas as contas existentes na Universidade, seja em máquinas corporativas, seja em redes locais.

O Sistema Unificado é alimentado automaticamente cada vez que uma conta é aberta.

O Sistema Unificado disponibiliza on-line:

a) emissão de Termo de Identificação e Compromisso;

b) informaçōes atualizadas aos Responsáveis por contas;

c) informaçōes ao Administrador de Rede Local sobre todas as contas dos usuários de sua Unidade ou Órgão.

A solicitação de abertura de contas, tanto em máquinas locais como em máquinas corporativas, se dá pelo preenchimento do Termo de

Identificaçăo e Compromisso, o qual deve ser assinado pelo solicitante e pelo seu Responsável.

Para solicitante com vínculo empregatício com a Universidade ou Professores Convidados, nos termos da Portaria GR 17/98, o Responsável é o seu chefe imediato.

Para alunos matriculados em đisciplinas e, ou, curso da Universidade, o Responsável é o Coordenador do Curso, ou o orientador no caso de alunos

com projetos de pesquisa.

Para os demais solicitantes, como os descritos abaixo, a responsabilidade fica assim definida:

pesquisadores visitantes e pós-doutorandos, terão como Responsável o professor que os convidou ou com o qual eles trabalham diretamente;

estagiários sem vínculo empregatício com a Universidade poderão solicitar a abertura de conta, a critério da Unidade. Neste caso, o Responsável é o

servidor ao qual suas atividades estão subordinadas; pesquisadores de instituições de ensino e, ou, de pesquisa que mantenham convênios com a

Universidade, aprovados pelos órgãos competentes, poderão solicitar a abertura de conta, a critério da

Unidade. Nesse caso, o Responsável é o

pesquisador ou docente executor do convènio na Universidade.

Servidor de empresas que mantenham convênios com a Universidade, devidamente aprovados pelos órgãos competentes, poderão solicitar a

abertura de conta, a critério da Unidade. Nesse caso o Responsável é o pesquisador ou docente executor do convênio na Universidade. 
A cada seis meses os Responsáveis receberão informaçōes atualizadas sobre as contas pelas quais se responsabilizaram.

Para abertura de contas em máquinas corporativas o solicitante deverá justificar porque a conta deverá ser aberta nas mesmas e não em máquina

local.

Para a abertura de contas em máquinas locais, inclusive para alunos, a Unidade ou Órgão responsável poderá definir normas adicionais, além das

aqui previstas.

Cabe ao Administrador de Rede Local controlar a validade da assinatura do Responsável.

Os Termos de Identificação e Compromisso ficam arquivados nas respectivas Unidades.

O Administrador de Rede Local entra no Sistema Unificado para formalizar a abertura da conta, fornecendo os dados do Termo de Identificação e

Compromisso.

O Sistema Unificado comunica automaticamente a abertura da conta ao Responsável pela sua autorização.

Para garantir a segurança da Rede da Universidade, o Sistema Unificado busca um único username para o usuário, mantendo-o igual em todas as

máquinas nas quais ele vier a ter conta.

Caso haja alteração de username, Unidade, Órgão, tipo de usuário ou responsável pela conta, deverá ser cancelada a conta original e ser aberta nova conta.

As senhas das contas nas máquinas corporativas serão trocadas, por razões de segurança a cada quatro meses pelo Centro de Computação. As

novas senhas criptografadas serão enviadas aos Administradores de Redes Locais para serem repassadas aos usuários.

As senhas das contas nas redes locais serão trocadas, por razões de segurança, a cada quatro meses, de acordo com mecanismos definidos pela

Unidade ou Órgão por elas responsável.

O tempo de validade de cada conta fica a critério de cada Unidade ou Órgão, cabendo ao Administrador de Rede Local a responsabilidade do seu controle.

O tempo máximo de inatividade de uma conta é de 6 (seis) meses. O usuário será avisado após quatro meses de inatividade da conta e quando da extinção da mesma. Cabe ao Administrador de Rede Local providenciar mecanismos para esse controle.

Fica a critério de cada Unidade ou Órgão realizar o recadastramento periódico de suas contas na rede local.

A conta será extinta assim que o usuário perder o vínculo com a Universidade.

As contas dos usuários definidos no item 4 serão extintas assim que as atividades ali previstas forem encerradas. Cabe aos Responsáveis por essas contas a comunicação imediata desse fato ao Administrador de Rede Local.

Penalidades 